\title{
EGG VTAP.6175
}

EGG-NTAP-6175

DE93 003077

\author{
INSERVICE LEAK TESTING OF \\ PRIMARY PRESSURE ISOLATION VALVES
}

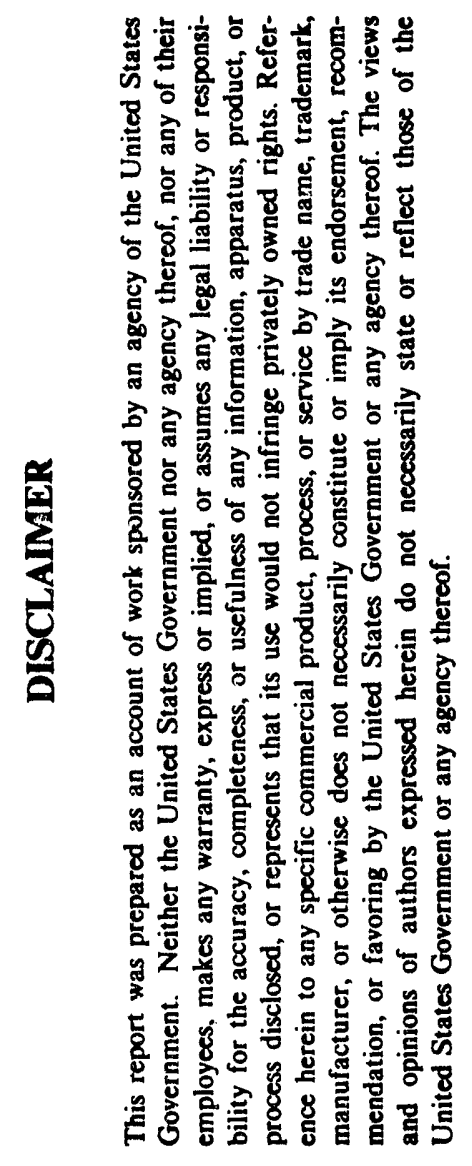

\author{
Published February, 1983 \\ R. A. Livingston \\ EG\&G IDAHO, INC. \\ Idaho Falls, Idaho 83415 \\ Prepared for the \\ U. S. Nuclear Regulatory Commission \\ Washington, D. C. 20555 \\ Under DOE Contract No. DE-ACO7-761001570
}

FIN No. A6367 


\begin{abstract}
The inservice leak testing of primary pressure isolation valves in commercial power reactors was investigated to identify problems with current test procedures and requirements. Nine utilities were surveyed to gather information which is presented in this report. An analys is of the survey information was performed, resulting in recommended changes to improve valve leak testing requirements currently invoked by Section $X I$ of the ASME Boiler and Pressure Vessel Code, Plant Technical Specifications, and Regulatory Guides addressing this subject.
\end{abstract}

FIN No. A6367 - EG\&G Idaho Final Report On Inservice Leak Testing of Primary Pressure Isolation Valves 
osure 2

\section{UTILITY INDEX}

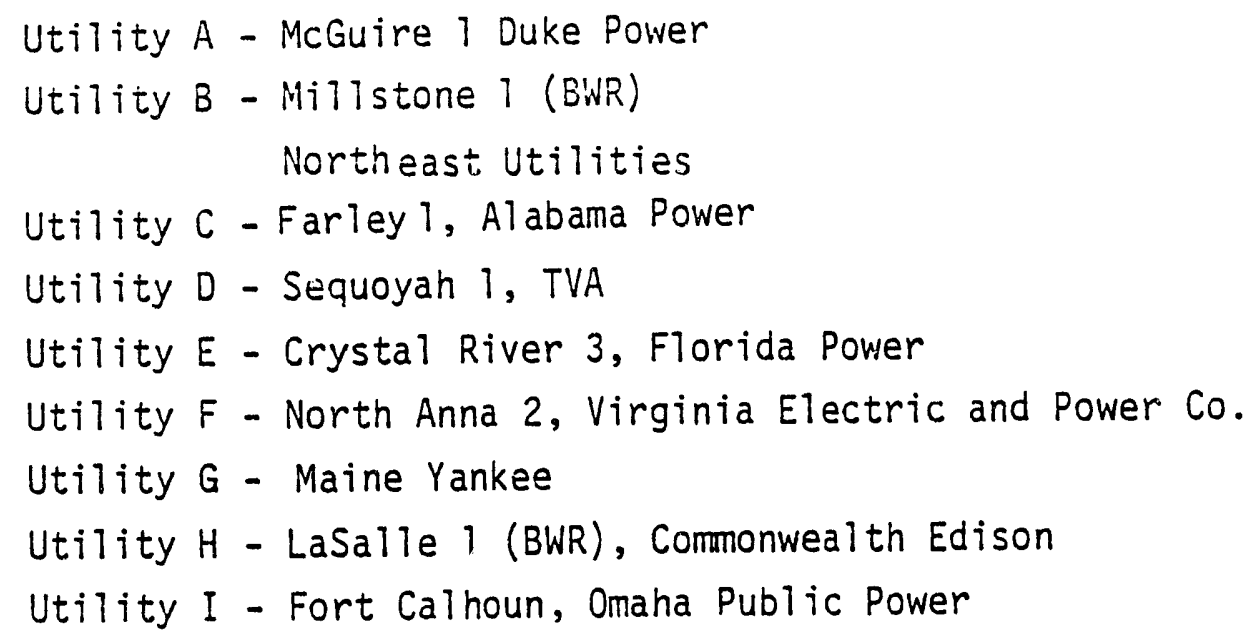


Accession No.

Contract Program or Project Title:

Support of NRC on ASME Boiler and Pressure Vessel Code,

Section XI Activities

Subject of this Document:

INSERVICE LEAK TESTING OF PRIMARY PRESSURE ISOLATION VALVES

Type of Document:

Final Report

Author(s): R. A. Livingston

Date of Document:

February, 1983

Responsible NRC Individual and NRC Offlce or Division:

E. T. Baker/Technical Monitor, Office of Nuclear Regulatory Research, Divison of Engineering Technology

This document was prepared primarily for preliminary or internal use. It has not received full review and approval. Since there may be substantive changes. this document should not be considered final.

EG\&G Idaho, Inc. Idaho Falls, Idaho $\mathbf{8 3 4 1 5}$

Prepared for the U.S. Nuclear Regulatory Commission Washington, D.C. Under DOE Contract No. DE-AC07-761001570 NRC FIN No. 46367 
SUMMARY

This report presents an analysis of the results of a survey of nine commercial power reactor owners concerning in-service leak testing of primary pressure isolation valves. It is apparent that the extrapolation of leakage data from reduced test pressure to the function pressure is potentially in error. Another apparent problem is the non-uniform interpretation of regulations on which valves require inservice testing. Recommendations are offered for improving the effectiveness of inservice leak testing, and for changing the leak test acceptance criteria. 


\section{NOMENCLATURE}

P Pressure, psia (absolute)

$\checkmark$ Fluid velocity, ft/sec

A Leakage flow area, in.2

$\Delta H \quad$ Head difference, ft.

$G$ Mass flux, ib/sec-ft

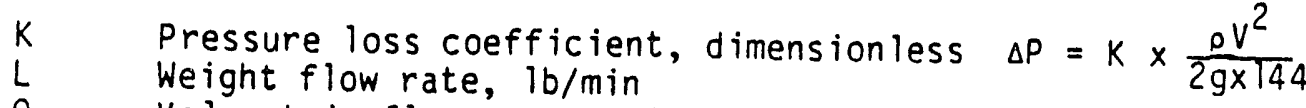

Q Volumetric flow rite, gal/min

D Hydraulic diameter, in. $=4 \times$ area/perimeter

g Gravitational constant $=32.2 \mathrm{ft} / \mathrm{s}^{2}$

$k \quad$ Gas adiabatic exponent $=1.4$ for air

$R \quad$ Engineering gas constant $=53.3 \mathrm{ft} /{ }^{\circ} \mathrm{R}$ for air

$T$ Temperature, ${ }^{\circ} \mathrm{R}\left(={ }^{\circ} \mathrm{F}+460\right)$

$P \quad$ Fluid density, $1 \mathrm{~b} / \mathrm{ft}^{3}$

$\triangle P \quad$ Pressure differential $P_{1}-P_{2}$, psid

$\mu \quad$ Fluid viscosity, lb-s/in.?

\& Length of flow path, in.

\section{Subscripts}

$\begin{array}{ll}1 & \text { Upstream of valve } \\ 2 & \text { Downstream of valive } \\ f & \text { Function as in plant operation } \\ t & \text { Test, as in valve leak test } \\ \text { a } & \text { Air } \\ w & \text { Water } \\ \text { sc } & \text { Subcooled } \\ c & \text { Critical }\end{array}$




\section{CONTENTS}

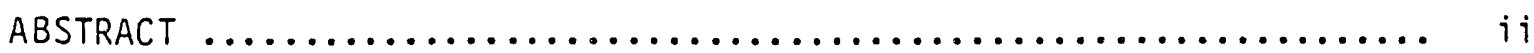

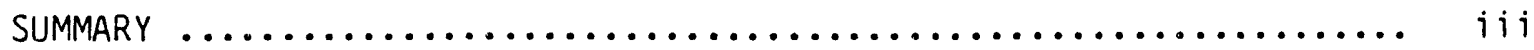

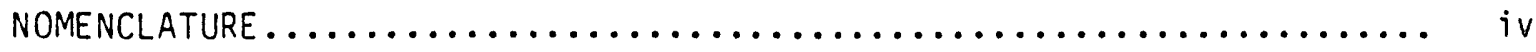

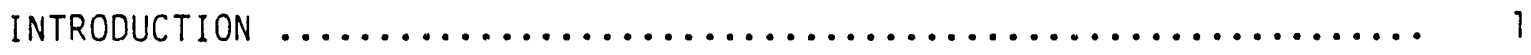

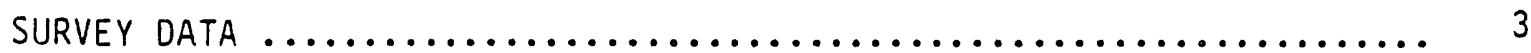

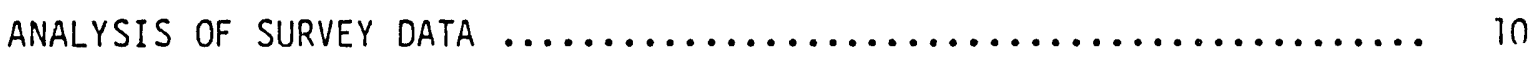

Leakage vs Valve Size and Type ....................... 10

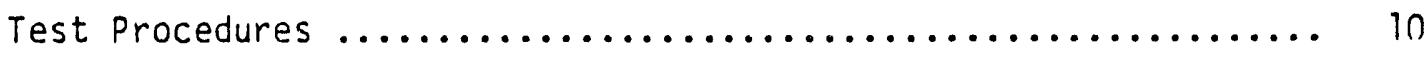

Correlation of Test and Function Conditions $\ldots \ldots \ldots \ldots \ldots \ldots$

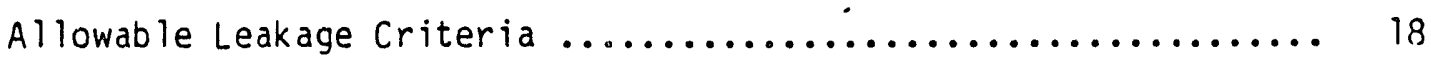

EFFECTS OF LEAKAGE ON OVERPRESSURIZATION $\ldots \ldots \ldots \ldots \ldots \ldots \ldots \ldots \ldots \ldots$

MAINTENANCE REQUIRED TO LIMIT LEAKAGE $\ldots \ldots \ldots \ldots \ldots \ldots \ldots \ldots \ldots \ldots \ldots$

REDUNDANT ISOLATION VALVES IN SERIES $\ldots \ldots \ldots \ldots \ldots \ldots \ldots \ldots \ldots \ldots \ldots \ldots \ldots \ldots \ldots \ldots \ldots$

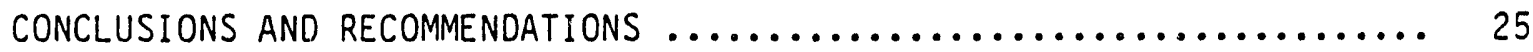

Valve Identification $\ldots \ldots \ldots \ldots \ldots \ldots \ldots \ldots \ldots \ldots \ldots \ldots \ldots \ldots \ldots \ldots \ldots \ldots$

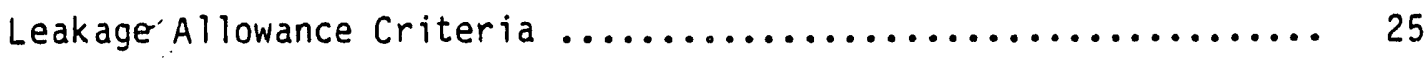

Testing Methods and Documentation .................... 27

APPENDIX A--ANALYSIS OF LIQUID AND GAS FLOW FOR

VALVE LEAK TESTING $\ldots \ldots \ldots \ldots \ldots \ldots \ldots \ldots \ldots \ldots \ldots \ldots \ldots \ldots \ldots \ldots$

\section{ATTACHMENTS}

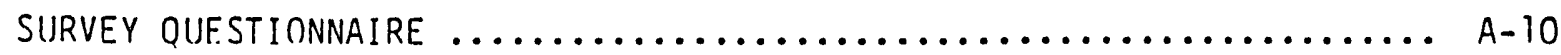

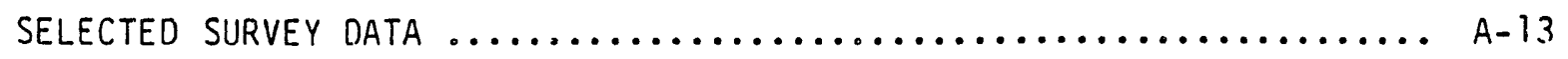


The owners of commercial nuclear power plants are required by the NRC to perform pericdic tests on valves that isolate primary reactor cooling system (RCS) water from interfacing safety systems. These in-service tests are intended to demonstrate the operability of the valves, and to identify leakage due to valve degradation before it progresses to a hazardous leve?. The identification of valves to be tested, test methods, and acceptance criteria are specified in the Plant Technical Specifications, and in most cases invoke the requirements of Section XI, Subsection IWV of the ASME Boiler and Pressure Vessel Code. The date of Operating License issue controls the edition and addenda of the ASME Code that utilities apply to in-service testing.

This report presents the results of a survey of nine commercial power reactor owners concerning their experience and opinions on the effectiveness and problems associated with in-service leak testing of primary pressure isolation valves. A copy of the survey letter requesting the information is attached (Reference 1). The information received from the utilities was analyzed with the objective of identifying potential changes to testing procedures and allowable leak-rates that would improve the effectiveness of the tests, and alleviate where possible, hardships imposed on the, utilities by the present requirements. The names of the nine commercial power reactor owners are not reported due to the limited information reported and the possibility of a misinterpretation of the reported information. The analysis and resulting recommendations were guided by the followilly restrictions and considerations:

1. Test procedures must yield unambigunus or conservative results (i.e., ambiguity and uncertainty are bounded)

2. Allowed valve leakage does not invalidate any Safety Analys is Report conclusions or compromise plant safety related design features

3. Flexibility in procedures is permitted to minimize impact of testing on utility operations 
4. The vaives tested, data analysis methods, and documentation are consistent from plant to plant

5. Test requirements are clear, concise, and practical to apply with minimized impact on plant operations and minimized exposure of personnel to radiation

6. Section XI of the ASME Boiler and Pressure Vessel Code should remain generic, with plant-specific testing requirements and criteria addressed by other means such as the Technical Specifications and Regulatory Guides. 


\section{SURVEY DATA}

The information obtained in response to the survey (attached) addressing in-service leak testing of primary pressurected materials in the summarized in the following table 


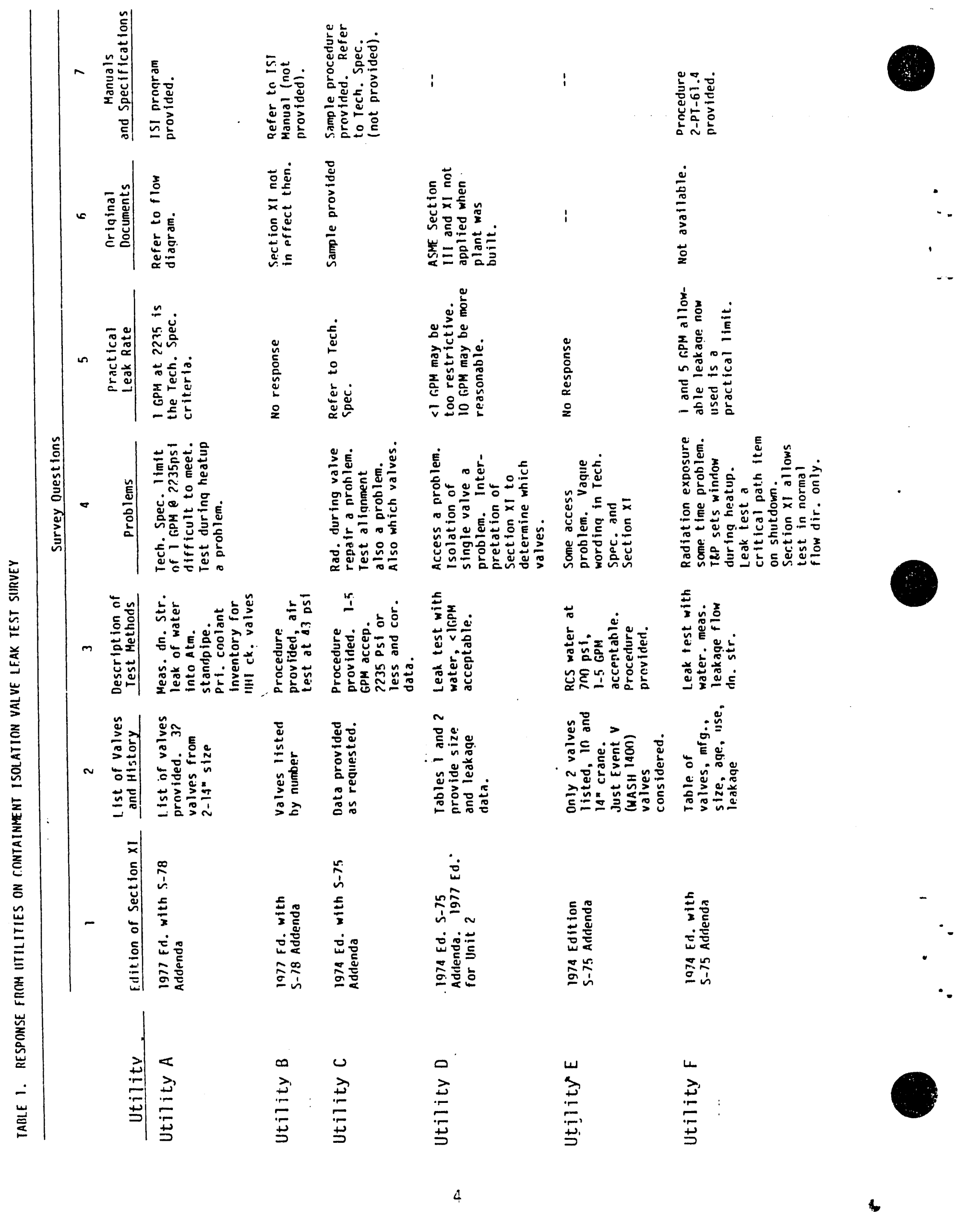




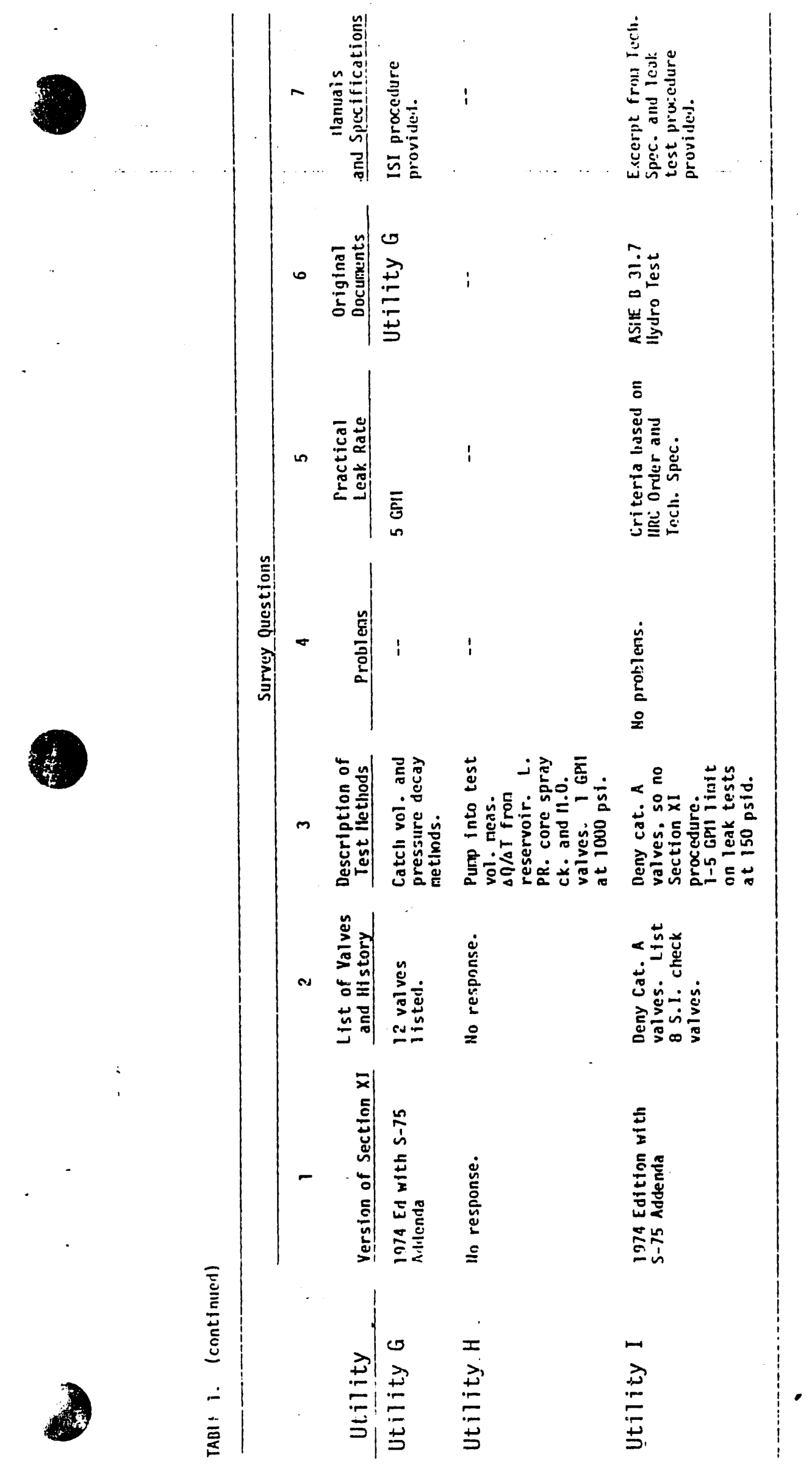




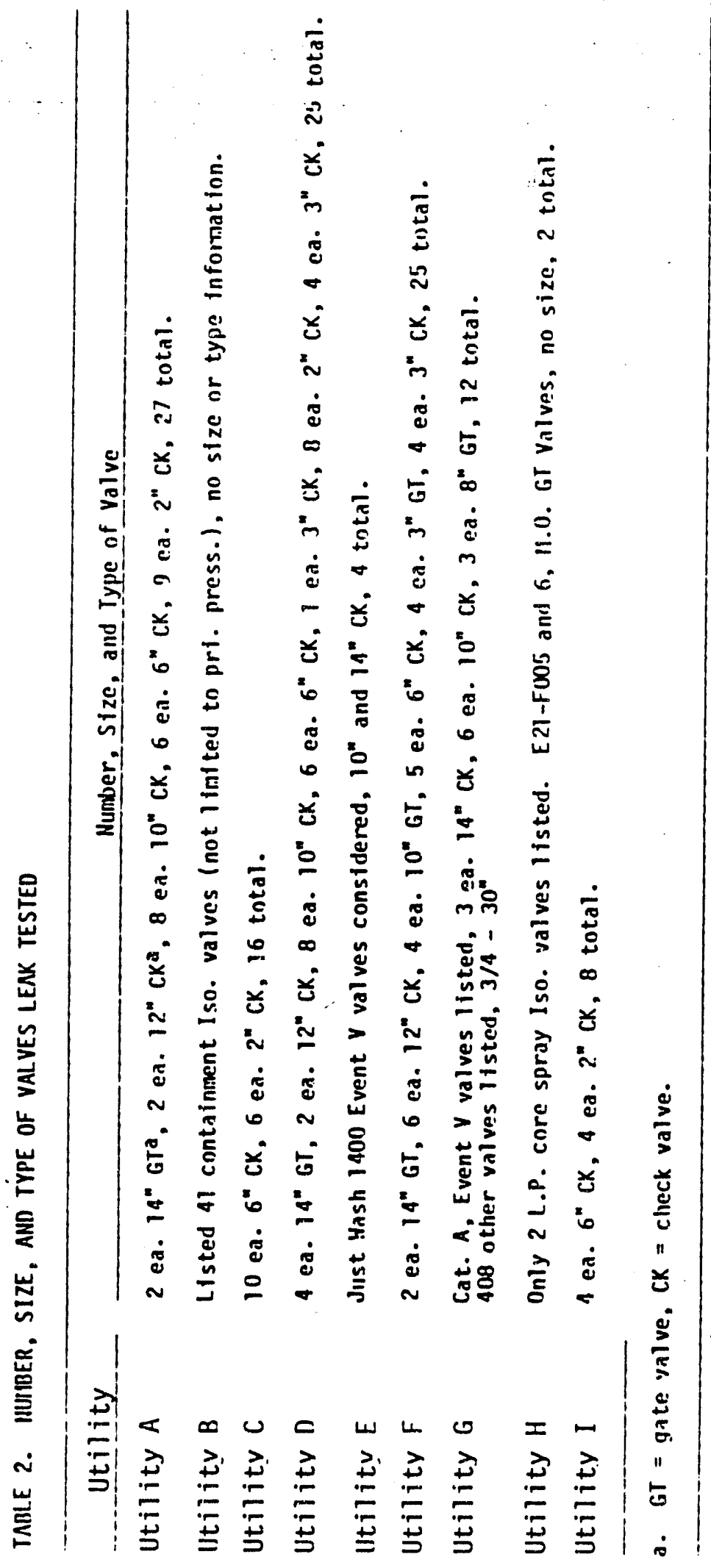




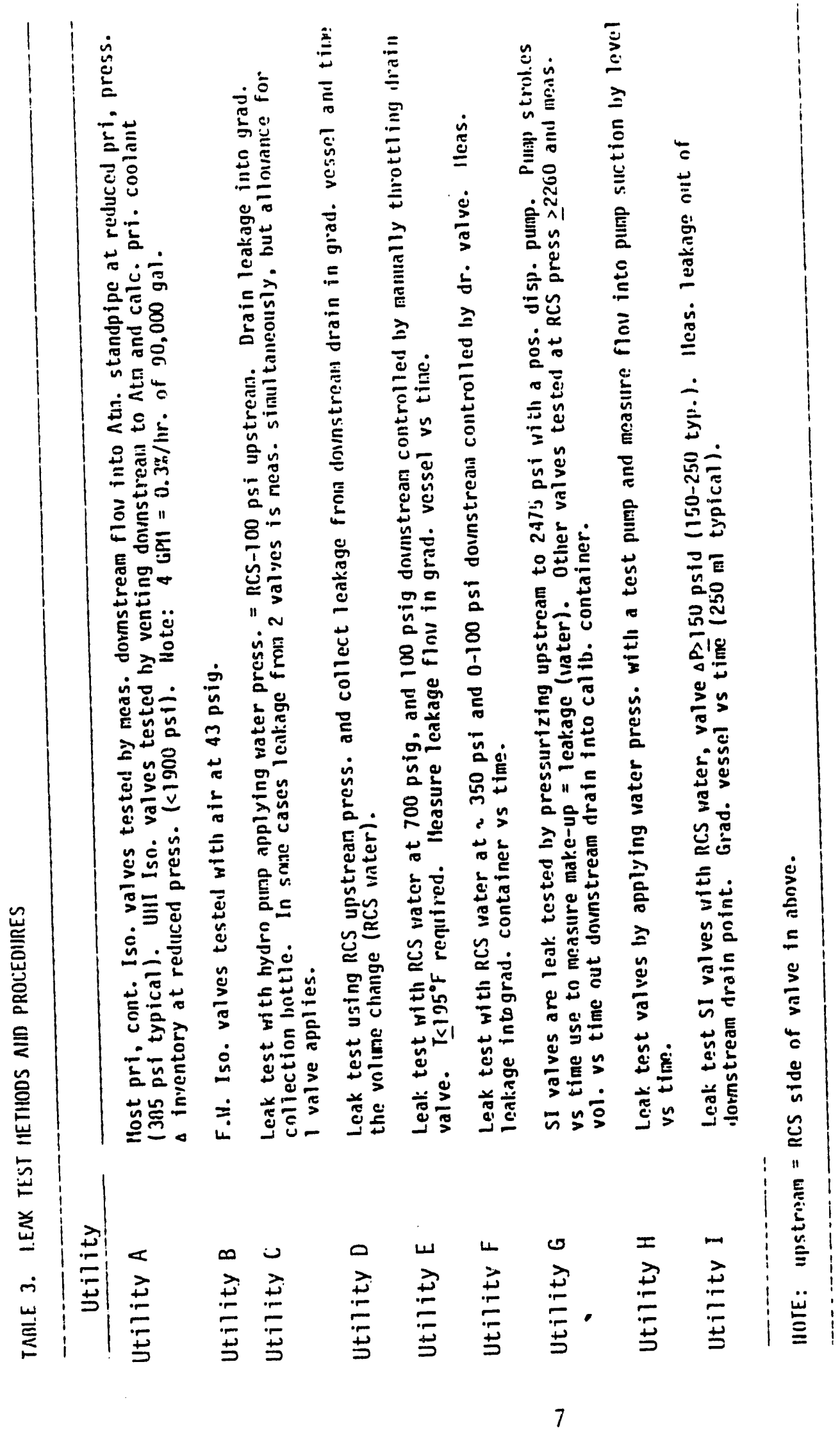




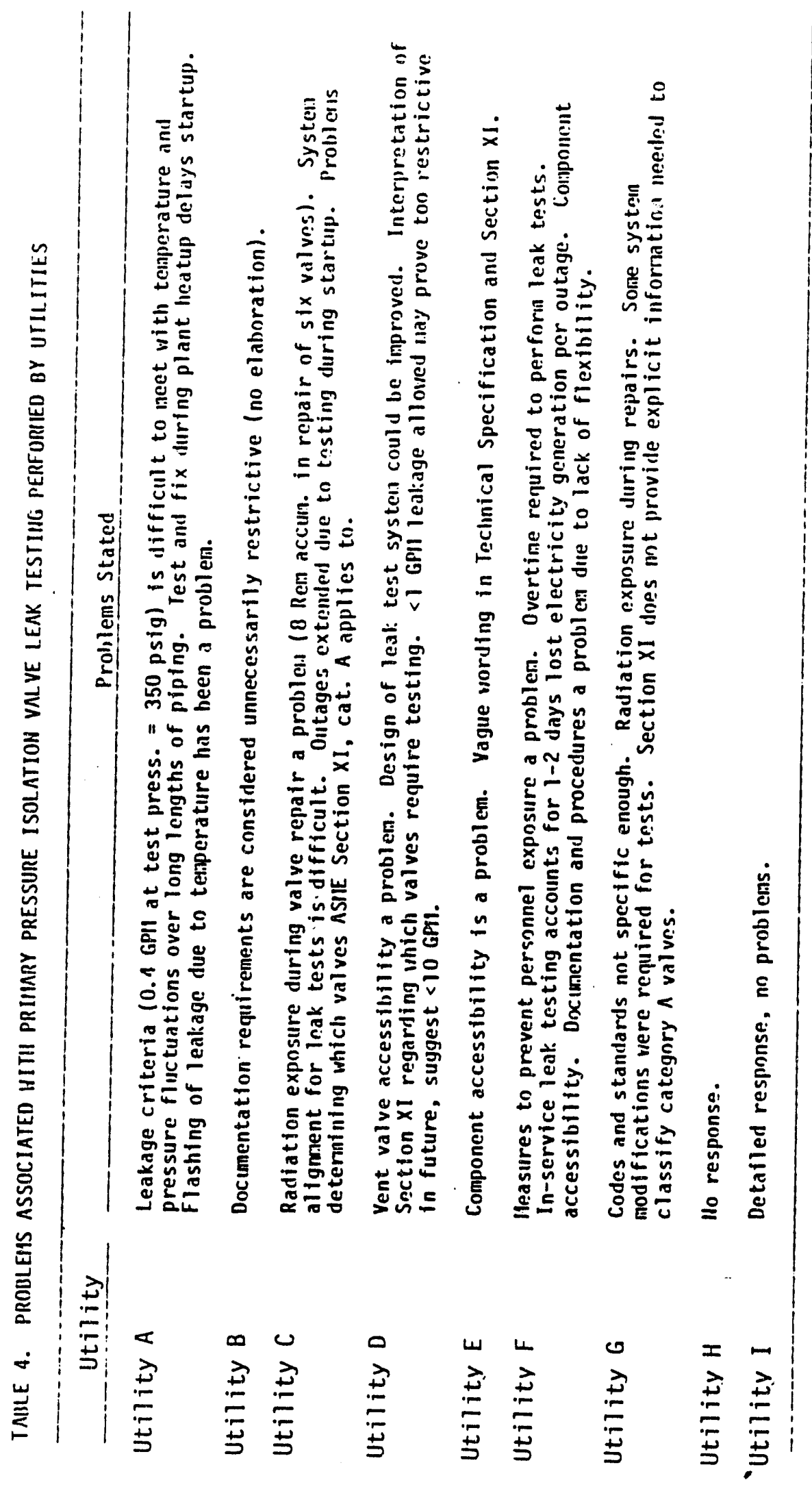




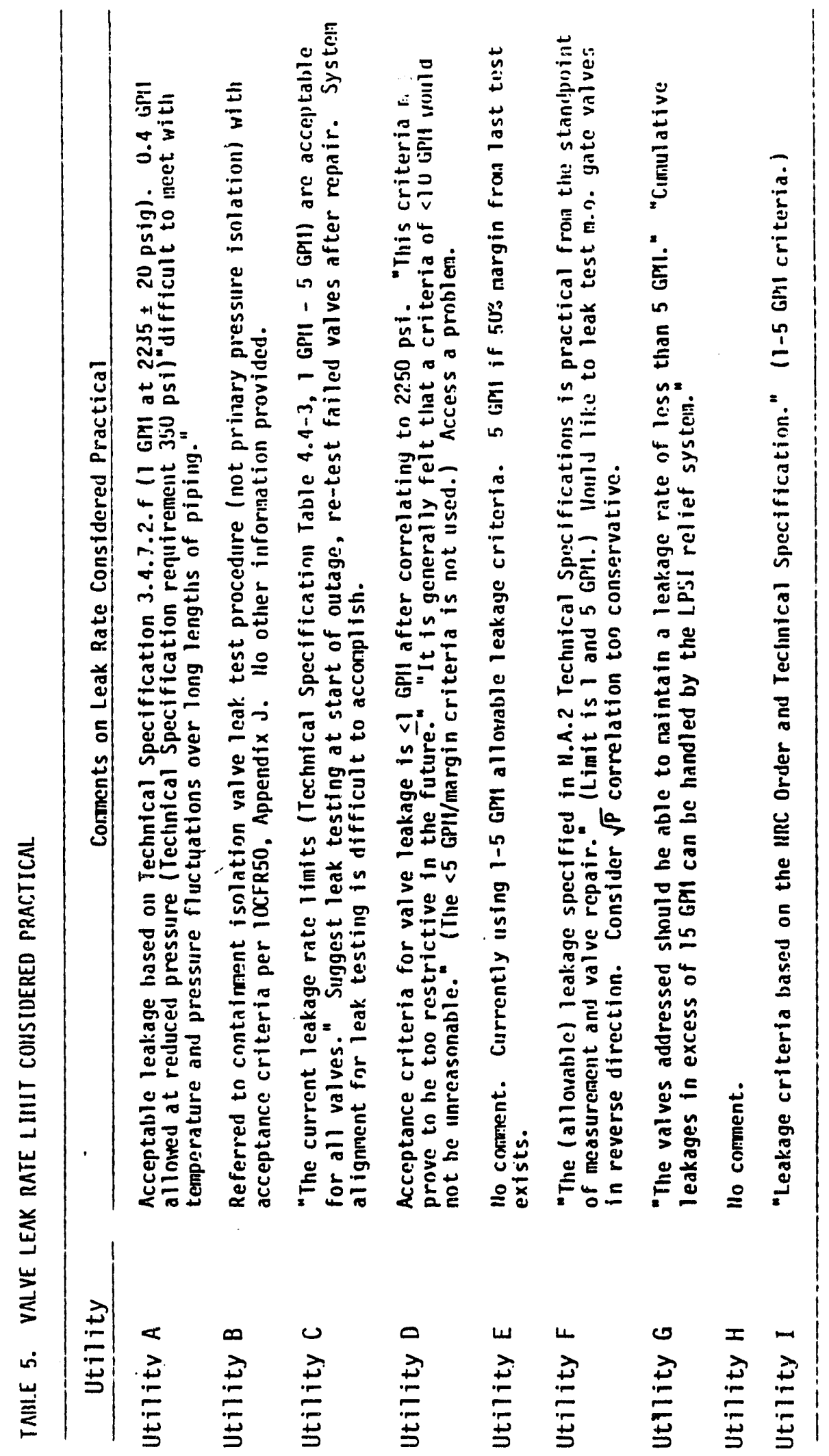




\section{Leakage vs. Valve Size and Type}

The acceptance criteria for primary pressure isolation valve leak tests currently in the Plant Technical Specifications is most often $1 \mathrm{gpm}$, or $5 \mathrm{gpm}$ if the margin since the last test has not been reduced in excess of $50 \%$. This leakage allowance is independent of valve type and size. In order to determine the desirability of making the allowable leakage a function of valve size, a plot of measured leakage vs valve size was prepared (Figure 1). This figure shows that the measured leakage is not a strong function of valve size. This data does not show the expected trend of larger valves having greater leakage, which may be due to the following factors:

1. Except for the initial test data, the valves have been required to rneet a leakage criteria $(1-5 \mathrm{gpm})$ that is independant of valve size. The larger valves may therefore have had more frequent maintanence to reduce leakage.

2. The data is from a limited number of valves.

3. The data is based on tests by different people using different methods in different valve installations.

The leakage data for check valves covers the size range from $1-1 / 2$ to $12 \mathrm{in.}$ The only data on gate valves is for 14-in. valves, and indicates the leakage is comparable to the check valves.

Since leakage for only one size of gate valve was reported, the correlation of gate valve leakage with size was not pursued.

\section{Test Procedures}

The most commonly employed test method is to apply reactor coolant system (RCS) water pressure on the RCS side of the isolation valve, then 

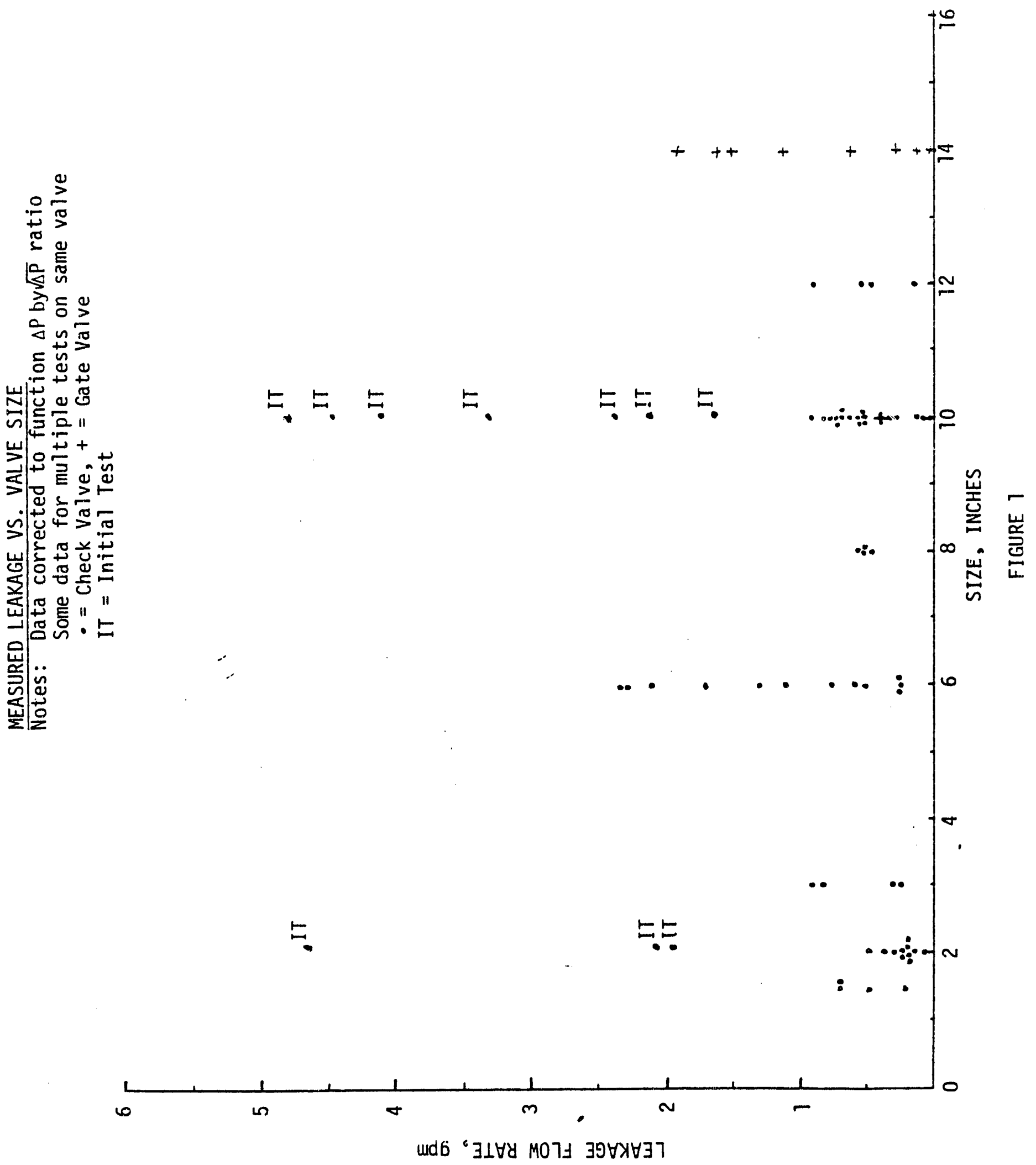
measure leakage out a vent or drain tap at atmospheric pressure on the downstream (for test) side of the walve. The RCS pressure maintained for leak testing is less than function pressure, with the test results correlated to function pressure by the $\sqrt{\Delta P}$ ratio as defined by the current version of the Code, Section XI. In several cases (Table 3 ), the downstream pressure is maintained above atmospheric.

Another test method used involves measuring the flow. pumped into the piping upstream (for test) of the valve being tested. For either of these methods to be unambiguous, the clrained leakage or supplied makeup must be the only source of flow out of or into the respective piping. This can be assured by controlling the pressure in interfacing systems such that all flow is into the piping downstream or out of the piping upstream of the valve being tested. This is not presently a stated requirement in the Code, Section XI or the Plant Technical Specifications (Reference 3 ). Another variable that has effected the accuracy of leakage flow measurements is the flashing or boiling away of part of the leakage flow. Test procedures that rely on draining the leakage flow into a graduated container at atmospheric pressure must be restricted to piping and fluid temperature below the boiling point $\left(212^{\circ} \mathrm{F}\right.$ at sea level). A nonconservative error in the measured leakage can also result due to local flashing at the valve seat, even though the downstream conditions are sufficiently subcooled to recondense the vapor. The phenomena of pressure recovery downstream from the minimum leakage area permits local flashing that reduces the flowrate due to two-phase losses occurring at the minimum area. In this case, the correlation of test leakage to function conditions by the $\sqrt{\Delta P}$ ratio results in an underprediction of function leakage, where the downstream pressure is higher and suppresses local flashing. This potential for error can be elimirated along with flashing and boil-off of the leakage flow by specifying that the liquid and component temperatures are subcooled by some margin relative to the downstream pressure. However, the margin required to suppress local flashing is a function of pressure recovery within the valve leak path and cannot be arbitrarily specified. An example of the reduction in water flowrate due to flashing is shown by comparing subcooled to saturated discharge rates. 
$V_{s C}=\sqrt{2 g \Delta H}=\sqrt{\frac{2 g \Delta P \times 144}{D}} \mathrm{ft} / \mathrm{sec}$

$G_{S C}=\rho V_{s c}=\sqrt{2 g \rho \Delta P \times 144} \mathrm{lbm} / \mathrm{sec}-f t^{2}$

For example at $\Delta P=285 \mathrm{psid}, \rho=62.4 \mathrm{lb} / \mathrm{ft}^{3}$,

$G_{S C}=12,842 \mathrm{lb} / \mathrm{sec}-f t^{2}$

The discharge of water at saturated upstream conditions of $300 \mathrm{psia}$, $h=394 \mathrm{Btu} / \mathrm{lb}, \mathrm{T}=417^{\circ} \mathrm{F}$ is given by Figure $9-10 \mathrm{a}^{\mathrm{a}}$ (Reference 4 ), and is $G_{C}=4600 \mathrm{lb} / \mathrm{sec}-\mathrm{ft}^{2}$.

This flowrate is only $36 \%$ of the subcooled discharge calculated above. The assumed condition of saturation temperature upstream is an extreme example, but serves to show the potential for error exists when a leak test with flashing is correlated with function conditions where flashing is suppressed by higher downstream pressure.

\section{Correlation of Test and Function Conditions}

The 1980 edition of the Code, Section XI (Reference 2), Paragraph IWV-3423 allows leakage testing at reduced $\Delta P$, with the function flow correlated to the measured flow by the $\sqrt{\Delta P}$ ratio. The calculations in Appendix $A$ and Reference 5, of this report, show that the $\sqrt{\Delta P}$ correlation is correct with the following limitations:

1. Leakage flow area and $K$ factor are constant

2. Flow is turbulent and subcooled

3. Fluid density is the same for test and function.

As shown by Equation (12) in Appendix $A$, when the flow is laminar (Reynolds No. $<2000$ ), the flowrate is proportional to $\Delta P / v i s c o s i t y$ rather than $\sqrt{\Delta P}$. Since the leak path dimensions are generally unknown,

a. Moody model for maximum critical discharge. 
the Reynolds number cannot be directly calculated to define which correlation is correct. The potential exists to underpredict the function leakage when the test leakage is laminar. This is because:

$\frac{\Delta P_{f}}{\Delta P_{t}}>\left[\frac{\Delta P_{f}}{\Delta P_{t}}\right]^{1 / 2}$ when $\frac{\Delta P_{f}}{\Delta P_{t}}>1$

where the subscripts $f$ and $t$ denote function and test.

The flowrate and corresponding Reynolds number were calculated using turbulent and laminar theory to investigate the potential for under prediction of function leakage. Assuming a deep scratch across the valve seat as the leak path, the "scratch" cross-sectional diameter required for $1 \mathrm{gpm}$ water leakage at $2250 \mathrm{psid}$ is 0.029 in. based on turbulent flow theory. $^{a}$ The corresponding Reynolds number is $2 \times 10^{5}$, indicating that the flow is turbulent and proportional to $\sqrt{\Delta P}$. The flow would not become laminar unless the test $\Delta P$ was reduced to less than 1 psid, since the Reynolds number of 2000 corresponds to a flow of only $0.010 \mathrm{gpm}$. This calculation shows that for a discrete "scratch" type leak mechanism, the flow is turbulent and correctly correlated between test and function $\Delta P$ by the ratio of $\sqrt{\Delta P}$.

Assuming that the leakage is caused by a small annular gap distributed all around the circumference of the valve seat, the gap size $e^{b}$ needed to produce $5 \mathrm{gpm}$ leakage at 2250 psid in valves ranging from 2 to $14 \mathrm{in.}$ nominal size is tabulated below, with the corresponding Reynolds number also shown:

a. Equation 3, Appendix A.

b. Through flow in Annuli, L. N. Tao and W. F. Donovan, Transactions of ASME, November 1955. 


\begin{tabular}{|c|c|c|c|}
\hline $\begin{array}{c}\text { Valve Size } \\
\text { (in.) }\end{array}$ & $\begin{array}{l}\text { Assumed } \\
\text { Seat Widtha } \\
(\text { in.) } \\
\end{array}$ & $\begin{array}{c}\text { Gap Size } \\
(\text { in.) }\end{array}$ & $\begin{array}{l}\text { Reynolds } \\
\text { Number } \\
\end{array}$ \\
\hline 2 & 0.062 & 0.00044 & 3435 \\
\hline 6 & 0.11 & 0.00037 & 1150 \\
\hline 10 & 0.18 & 0.00037 & 687 \\
\hline 14 & 0.25 & 0.00037 & 490 \\
\hline
\end{tabular}

The above tabulation shows that for leakage through a distributed gap, the flowrate is laminar for valves larger than $2 \mathrm{in}$. at the function $\Delta P$. For laminar flow, the flowrate is proportional to $\Delta P$ rather than the $\sqrt{\Delta P}$ as for turbulent flow. Therefore, a valve leakage measured at reduced $\Delta P$ test conditions should be correlated to the function $\Delta P$ by the ratio of $\Delta P^{\prime} s$. Correlating leakage by the $\sqrt{\Delta P}$ ratio now in the Code, Section $X I$, results in underprediction of the function leakage when laminar conditions exist. For example, a 10-in. valve with a distributed leak gap around the seat of $0.00046 \mathrm{in}$. would leak $2.2 \mathrm{gpm}$ at a test pressure of $500 \mathrm{psid}$. The Reynolds number is 306 indicating laminar flow. Incorrect correlation of the leakage to the function $\Delta P$ of 2250 by the $\sqrt{\Delta P}$ ratio predicts $4.7 \mathrm{gpm}$. Laminar theory predicts the leakage at function $\Delta P$ to be $9.9 \mathrm{gpm}$, at which the Reynolds number is 1400 , indicating the flow is still laminar. Incorrect application of the $\sqrt{\Delta P}$ correlation results in a $110 \%$ error, underpredicting the leakage at the function $\Delta P$ in the above example.

The use of the $\sqrt{\Delta P}$ correlation is also incorrect when the test fluid is a compressible gas and the function fluid is incompressible or vice-versa. Using gas as the test fluid with the downstream pressure atmospheric, the upstream pressure need only be 28 psig or higher to produce sonic choking of the leakage flow. As shown by Equation ( 9 ) in Appendix $A$, the upstream volumetric gas flow is then proportional to the

a. From conversations with manufacturers, the seating surface of $10 \mathrm{in}$. check valve is about $1 / 8 \mathrm{in}$. wide, the seating surface of $14 \mathrm{in.M.0.} \mathrm{gate}$ value is about $3 / 16$ in. wide. 
square root of the upstream temperature, and independent of upstream pressure. Critical gas flow therefore cannot be correlated with function water flow by the $\sqrt{\Delta P}$ factor given in the code.

A calculation comparing critical with sub-critical compressible gas flow through an assumed leak path indicates that the error is small if sub-critical flow is extrapolated to critical flow conditions. For flow through a "scratch" geometry of 0.029 in. diameter, with 5 psig pressure upstream and atmospheric (14.7 psia) downstream, the pressure ratio is 0.746 which is subcritical. The subcritical flow equation a predicts an upstream flow of $1.23 \mathrm{gpm}$. The critical flow equation (Equation 5, Appendix A) incorrectly applied at this pressure ratio, predicts a flow of $1.4 \mathrm{gpm}$. It is apparent that the correlation of air flowrates can be made using Equations 5 through 10 in Appendix A without significant error even if the air flow is somewhat subcritical. At very low pressure drops, the error will be larger and a strict analys is of the actual flow condition would be in order.

The utility response to the questionnaire included two instances of test-to-function leakage correlation using other than the $\sqrt{\Delta P}$ correlation. Neither case applied to primary pressure isolation valve leak testing, but were used for other purposes. In one case, the water leakage data on containment isolation valves is correlated to function gas flow by the ratio of $\Delta P / v i s c o s i t y$. This is correct only for noncritical, subcooled laminar flow with negligible compressibility effects. These restrictions were not addressed.

A comparison of the air leak rate predicted by critical flow theory to the laminar flow correlation of air and water flow used by one of the utilities ${ }^{b}$ for containment isolation valve leak testing (not primary pressure isolation valve) is shown below:

\footnotetext{
a. Vennard, Elementary Fluid Mechanisms.

b. Utility G, Procedure No. 3.17.4, Appendix A, Revision 6, page 6.
} 
Assume for comparison:

$P($ air $)=P($ water $)=55$ psig $=69.8 \mathrm{psia}$

$T($ air $)=T($ water $)=70 F=530 R$

Leakage flow area $=0.001 \mathrm{in}^{2}(D=0.036$ in. diameter $)$

$K=$ form loss factor $=1.0$

for turbulent water flow, [Appendix A, Equation (3)]

$$
\begin{aligned}
Q_{W}=236 D^{2} \sqrt{\frac{\Delta P}{o K}}=236 \times 0.036^{2} \times \frac{55}{62.4} & =0.29 \mathrm{gpm} \\
& =1090 \mathrm{cc} / \mathrm{min}
\end{aligned}
$$

for critical airflow, [Appendix A, Equation (5)]

$$
\begin{aligned}
L a=3600 \sqrt{\frac{g k}{R}\left(\frac{2}{k+1}\right)^{k+1 / k-1}} \times \frac{A P_{1}}{\sqrt{T_{1}}} & =3600 \sqrt{\frac{32.2 \times 1.4}{53.3}\left(\frac{2}{2.4}\right)^{6}} \times \frac{0.001 \times 55}{\sqrt{530}} \\
& =4.6 \mathrm{lb} / \mathrm{hr}=110 \mathrm{lb} / \mathrm{day}
\end{aligned}
$$

ratio of $\frac{\text { a ir leak rate }}{\text { water leak rate }}=\frac{110 \mathrm{lb} / \text { day }}{1090 \mathrm{cc} / \mathrm{min}}=0.1 \frac{\mathrm{lb} / \text { day (air) }}{\mathrm{cc} / \mathrm{min} \text { (water) }}$

\begin{tabular}{|c|c|c|}
\hline$L \cdot R$. & $=$ & air leakage rate (function), $1 \mathrm{bm} / \mathrm{day}$ \\
\hline & $=$ & water viscosity $=1.0$ Centipoise at $70^{\circ} \mathrm{F}$ \\
\hline & $=$ & water leakage rate (test), cc/min \\
\hline & $=$ & drop $($ functjon $)=55$ psid \\
\hline & $=$ & water pressure drop (test) $=55$ psid. \\
\hline
\end{tabular}

from the referenced utility correlation:

$L . R .=\mu w L \frac{P_{a}}{P_{w}}$

where: 
This equation at the assumed conditions yields a leakage ratio of $\frac{\text { air leak rate }}{\text { water leak rate }}=\frac{L . R .}{L}=\mu w \frac{P_{a}}{P_{w}}=1.0 \frac{55}{55}=1.0$.

Note that the laminar flow utility correlation overpredicts the air (functioil) leakage rate by a factor of 10 if turbulent water flow and choked airflow conditions exist. This is a conservative error which may result in more maintenance on valves than is actually required.

In the other case, valve repair is checked by leak testing with air, measuring the upstream volumetric flow at a critical pressure ratio of 0.43 . The leakage allowance was $0.1 \mathrm{gpm}$. An interesting relationship, shown in Appendix $A$, is that for a function $\Delta P$ of 2250 psid and an air test temperature of $100^{\circ} \mathrm{F}$, the ratio of upstream volumetric flowrates

$$
\frac{Q w}{Q a}=0.863,
$$

hence the $0.1 \mathrm{gpm}$ test air allowance is very conservative relative to a $1 \mathrm{gpm}$ function allowance for these specific conditions.

\section{Allowable Leakage Criteria}

Excessive leakage of RCS water into lower pressure interfacing systems such as the HPSI, LPSI, RHR, and accumulator systems is a safety concern because of the following:

1. Leakage from the RCS, together with other sources may exceed the flow capacity of the pressure relief system, causing overpressurization of a lower pressure system

2. A large allowance of identified leakage through primary pressure isolation valves may make it more difficult for leakage detection systems to identify small but important increases in unidentified leakage (Reference 7 ) 
3. Leakage of radiologically contaminated RCS water may exceed the processing capacity of waste water cleanup systems

4. This allowed breach of containment may increase the probability of uncontrolled fission product release under certain accident conditions.

While the scope of this study is limited to the first of the three safety concerns listed above, a brief examination of the radiological transport associated with current leakage limits is presented for information. The Standard Technical Specification (Reference 3) permits unlimited reactor operation with a RCS water specific activity of $1.0 \mu \mathrm{C} / \mathrm{gm}^{\mathrm{a}}$, and limited operation with up to $275 \mu \mathrm{C} / \mathrm{gm}$. At the maximum allowed primary pressure isolation valve leakage rate of $5 \mathrm{gpm}$, the leakage of activity is:

$C=5 \mathrm{gpm} \times 3785 \mathrm{gm} / \mathrm{gal} \times 60 \frac{\mathrm{min}}{\mathrm{hr}} \times 275 \times 10^{-6} \mathrm{c} / \mathrm{gm}$

$=312 \mathrm{C} / \mathrm{hr}$ per valve leaking $5 \mathrm{gpm}$.

An assessment of the potential radiological releases associated with this allowed activity leak-rate would require an analysis of plant processes and the probability of failures in containing mechanisms.

a. Dose Equivalent $[-131$. 
Overpressure protection is provided by relief valves or other devices having a flow capacity based on the predicted sources of flow and energy input into the protected system, and the design pressure rating. Leakage through valves separating high pressure from lower pressure systems is a potential source of overpressurization. Leak testing is therefore essential for identifying valve degradation before the leakage increases to a value that may exceed the relief capacity of the interfacing system.

The 1980 edition of the ASME Code, Section XI, Subsection IWV-3426 provides that the permissible leakage rate of specific valves may be specified by the Owner (utility). If not specified by the Owner, the leakage rate permitted by the code is:

1. For water, at function $\Delta P, 300 \mathrm{ml} / \mathrm{hr}(0.00013 \mathrm{gpm} / \mathrm{in}$. nominal valve size)

2. For air, at function $\Delta P, 7.50 \mathrm{Std} . \mathrm{ft}^{3} / \mathrm{day}$ where $D$ is the nominal valve size, inches.

Section XI of the Code does not address the potential for valve leakage to cause overpressurization of the leaked-into system. However, the permitted leakage ( 1 and 2 above) is so small that it is very unlikely to effect the pressure in a system having overpressure protection from other sources. It is therefore the responsibility of the owner, in specifying the allowable leakage for specific valves, to assure that:

1. The maximum allowable leakage specified should not exceed the value allowed for that valve in the analys is of overpressure protection system requirements on which the pressure relief design is based

2. If the leakage source was not included in the overpressure protection analysis, the allowed leakage must be a negligible contribution to avoid exceeding the capacity of the pressure relief valves. 
The previously quoted leakage permitted by Section XI of the Code $(0.00013 \mathrm{gpm}$ per inch valve size) surely meets Criterion 2 above. The 1 gpm allowance specified in the Standard Technical Specifications for Westinghouse PWRs (Reference 3, Paragraph 3.4.6.2 f) probably also meets Criterion 2, although this question was not addressed in the utility survey. For example, literature on commercial pressure relief valves shows a one-inch relief valve with the smallest available orifice $\left(0.11\right.$ in. $\left.{ }^{2}\right)$ has a flow capacity of $22 \mathrm{gpm}$ at $150 \mathrm{psi}$ with $10 \%$ accumulation. A system protected by this small relief valve would experience very little pressure increase due to an extra flow source of $1 \mathrm{gpm}$. Of greater concern is potential leakage into a system which could be isolated from overpressure relief systems.

For plants constructed in accordance with the ASME Code, Section III, the requirements of Subsections NB-7000 and NC-7000 (Class 1 and 2 systems) include an Overpressure Protection Report containing "an analys is of conditions that give rise to the maximum pressure relieving requirements." ${ }^{a}$ For plant systems of lower design pressure than the RCS that interface with the RCS via isolation valves, the owner could specify allowed leakage in excess of the 1-5 gpm currently allowed as long as the Overpressure Protection Report documents that the allowed leakage was specifically included in the analysis and design of the pressure relief system.

a. NB/NC-7220. 
Two manufacturers of valves of the type used for primary pressure isolation were contacted for information pertaining to valve leakage, with the following response:

1. Question: What is the configuration of the valve seat sealing surface?

Response: For a 10-in. check or gate valve, the seat is a lapped flat surface about $1 / 8-$ in. wide adjacent to a shallow tapered surface.

2. Question: What leakage criteria is recommended for valves in high pressure water service?

Response: Most valve procurements specify Manufacturers Standardization Society Standard Practice SP-61, which allows a maximum of $10 \mathrm{cc} / \mathrm{hr} / \mathrm{in}$. valve size at 3100 psig for 1500-1b class valves. They have not been called upon to supply or maintain valves with $1 \mathrm{gpm}$ leakage allowance, and don't appreciate why such a large allowance is needed.

3. Question: What is the estimated cost of maintaining a $1 \mathrm{gpm}$ leakage allowance for valves in the 10-in. 1500-1b class size?

Response: Their only experience is the work required to meet the criteria of SP-61 quoted above, which requires about $2 \mathrm{hr}$ to lap the seats from the as-machined condition.

4. Question: What mechanisms have been identified for leakage increasing with service time for valves installed in high pressure water systems? 


$$
\begin{aligned}
& \text { Response: The most common cause of gate valve deterioration is } \\
& \text { cycling the valve dry prior to operation in service } \\
& \text { with water. They could offer no explanation or } \\
& \text { experience with check valve deterioration or leakage } \\
& \text { increase as a function of time. }
\end{aligned}
$$

As may be seen from the above response, these valve manufacturers have not had to consider the cost and radiation exposure associated with meeting a leakage criteria for valves installed in a commercial nuclear power plant. The small leakage allowance in MSS SP-61,0.0004 gpm for a 10-in. valve, is relatively inexpensive to achieve in new valves at the factory. 


\section{REDUNDANT ISOLATION VALVES IN SERIES}

A conclusion of the Reactor Safety Study (WASH 1400) is that an Interfacing Systems LOCA due to failure of the redundant LPIS check (isolation) values is a potential event of relatively high probability $\left(4 \times 10^{-6} / \mathrm{yr}\right)$. Since one of the bases for the valve leakage limit is to prevent overpressurization of the interfacing system, it follows that for redundancy, both of the isolation valves must comply with the leakage limit that precludes overpressurization of the interfacing system. While an isolation value leak of a few $\mathrm{gpm}$ is unlikely to exceed the pressure relief capacity of a large system such as the LPIS, the allowance of a higher leakage rate for the valves of a redundant set should not be made without that allowance being specifically addressed in the overpressure protection analys is for the interfacing system. 
The following conclusions and recommendations concerning leakage through primary pressure isolation valves are based on the survey responses and analysis work presented in this report.

\section{Valve Identification}

A problem identified by plant operaters is inadequate guidance in selecting specific valves that should be included in their inservice testing program. The Draft Regulatory Guide "Identification of Valves for Inclusion in Inservice Testing Programs", dated October, 1982 describes criteria that will help plant operators identify the safety-related valves that should be included in an inservice testing program. Interpretation of this Guide would ideally result in the owners of similar plants presenting similar lists of valves for their required inservice testing programs. To achieve consistancy of interpretation, it may be desirable to supplement the guide with a more definitive methodology whereby plant operating personnel would be lead through a valve selection process. Recognizing that the Guide must remain nonplant-specific, the development of a useful methodology appropriate for all plants may not be feasable. If this is found to be the case, uniform and consistant valve testing among the many plant owners could be achieved by having their testing requirements coordinated by a technical support firm competant in this field.

\section{Leakage Allowance Criteria}

1. The allowance of $1-5 \mathrm{gpm}$ leakage currently invoked in Plant Technical Specifications is generally considered practical to achieve, and was not reported to be challenging the pressure relief capacity of interfacing systems. The Section $X I$ alternative to owner specified leakage allowance is essentially zero, and should so remain to prevent this allowance from affecting the requirements of Section III of the Code which defines overpressure protection requirements.

2. The current Technical Specification allowances of up to $5 \mathrm{gpm}$ leakage for older plants, and $1 \mathrm{gpm}$ for newer plants should be changed to make the leakage allowance proportional to valve size, and the same for all 
nominal valve size at function $\Delta P$, with a maximum of $5 \mathrm{gpm}$ allowed regardless of valve size. This recommendation is based on the following factors:

a. As shown by the survey responses, new valves, supplied from the factory with nearly zero leakage, can leak in excess of $1 \mathrm{gpm}$ after installation in the plant due to such factors as dry-cycling, distortion clue to body welds, and contamination during construction. The rework required to reachieve less than I gpm leakage should be comparable for new and old valves. The seat lapping process used in the factory requires about two hours of labor after the valve is disassembled.

b. The leakage allowance should be proportional to valve size because the sealing surface circumference, or potential for leakage is so proportioned. This is recognized in the valve Manufacturers Standard MSS SP-61, which allows $10 \mathrm{cc} / \mathrm{hr} / \mathrm{in}$. valve size.

c. A maximum leakage allowance of $5 \mathrm{gpm}$ should be routinely achievable by plant maintenance personnel using lapping equipment designed specifically for valve rework.

d. Allowance of more than $5 \mathrm{gpm}$ leakage is not recommended because:

(1) If not accounted for in the Over Pressure Protection ${ }^{\text {a }}$ analysis, the pressure relief valve in a small system may not be able to accommodate more flow without exceeding system pressure limits.

(2) Larger leakage allowances would tend to mask the detection of unidentified leakage from the primary system, which is currently limited by the Standard Technical Specification to $10 \mathrm{gpm}$ ( see References 3 and 7 ).

a. ASME B\&PV Code, Section III, Div. 1, SS NB/NC-7000. 
(3) This leakage should be limited to limit fission product distribution from the primary coolant to plant systems outside the containment that are relatively free of contamination.

e. The criteria that the margin between measured leakage and the maximum allowed leakage shail not have decreased by more than $50 \%$ since the last scheduled leak test should be retained. This will reduce the chance that a deteriorating valve will substantially exceed its leakage limit between scheduled ISI leak tests.

3. The owner should be allowed the option of a higher allowance of leakage for specific valves only if justified by a documented analysis of overpressure protection and radiological processing capability showing that code Section III and FSAR conclusions are not violated by the higher leakage allowance.

4. The question of radiological hazards associated with primary pressure isolation valve leakage should be addressed by a preliminary scoping analysis of the potential for release to the environment from this source. Under accident conditions, the specific activity of the RCS water may considerabiy exceed the Technical Specification limits. The specific activity of TMI RCS water measured one month after the accident was $1876 \mu \mathrm{C} / \mathrm{mL}$ (Reference 6 ). Five gpm leakage of this specific activity results in an activity leakage of $2130 \mathrm{c} / \mathrm{hr}$.

\section{Testing Methods and Documentation}

1. The flexibility currently allowed in testing methods should be retained to accommodate the variety of individual plant design features and operating practices. However, the test condition constraints needed to assure valid results should be identified either in the code or the Plant Technical Specifications. The following constraints have been identified in this report. 
a. System pressures must be controlled to assure the measured leakage is no less than the leakage through the valve being tested (i.e., alternate paths are not accepting some of the leakage). Since this involves plant-specific design features, this requirements should be invoked in the plant Technical Specifications.

b. The temperature of the test fluid and piping must be sufficiently subcooled relative to the downstream pressure to assure no leakage is vaporized and local interna! flashing is suppressed. This should be a general requirement invoked in the code.

c. The correlation of function leakage to test leakage must account for the actual fluid conditions. The $\sqrt{\Delta P}$ correlation currently in the Code is only valid for turbulent, subcooled, incompressible flow. The code should include the restrictions that apply to the $\sqrt{\Delta P}$ correlation and include other correlations as appropriate.

2. A test program should be performed to document the accuracy and limitations of leak-rate correlations as affected by flow media, thermal effects, and pressure drop. The tests would involve leak testing several representative valves over a range of fluid conditions to validate existing or new correlations specified in the code.

3. To the extent feasible, a standard format should be used by all utilities to document test conditions, methods, data, calculations, and correlated function leakage. The resulting consistency would help identify and correct errors in the testing process, and ease the burden of interpretation by plant operations personnel. 
4. Valve leak testing required during plant startup rather than during shutdown places testing and repair activities on the schedule critical path. This has extended scheduled outages by $1-2$ days. Since most valves are designed for repeatable seat leakage performance, the NRC should consider allowing leak testing during the plant cooldown phase to permit operators to repair failed valves during the scheduled outage. Tests on the repeatability of valve seating leak-tightness would be useful in supporting a decision on this matter. 


\section{REFERENCES}

1. Transmittal of Valve Survey Sheet, letter from B. F. Saffel, Jr. to R. E. Tiller (DOE-ID), August 20, 1981.

2. ASME Boiler and Pressure Vessel Code, Section XI, Subsection IWV, 1980 edition.

3. Standard Technical Specifications for Westinghouse Pressurized Water Reactors, NUREG-0452, Revision 4.

4. The Thermal Hydraulics of a Boiling Water Reactor, R. T. Lahey and F. J. Moody.

5. Calculations by A. G. Ware, letter from B. F. Saffel to R. E. Tiller, November $30,1981$.

6. Letter from J. T. Collins, USNRC to C. W. Sill, May 22, 1980.

7. Regulatory Guide 1.45, Reactor Coolant Pressure Boundary Leakage Detection Systems. 
APPENDIX A

ANALYSIS OF LIQUID AND GAS FLOW FOR

VALVE LEAK TESTING

\section{Introduction}

The ASME Boiler and Pressure Vessel Code, Section XI, Subsection IWV, 1980 edition, allows ISI leak testing of certain valves at lower than functional pressure differential [IWV-3423 (e)] with test medium the option of the Owner (IWV-3425). The measured leakage rates for tests performed at less than the functional pressure differential "shall be adjusted to the function maximum pressure differential value. This adjustment shall be made by calculation appropriate to the test media and the ratio between test and function pressure differential, assuming leakage to be directly proportional to the pressure differential to the one-haif power" [Reference IWV-3423 (e)]. The acceptance criteria is the option of an owner specified maximum leakage rate, or the values specified in the code (IWV-3426) which are:

1. For water, at function pressure differential, $300 \mathrm{~mL} / \mathrm{hr}$ which is $0.00013 \mathrm{gpm} / \mathrm{in}$. valve size

2. For air, at function pressure differential, $7.50 \mathrm{Std} . \mathrm{ft}^{3} / \mathrm{day}$ which is $0.039 \mathrm{gpm} /$ in. valve size

$D$ in the above formulas is the nominal valve size, in.

This appendix contains an analys is of the adjustment needed to correlate measured valve leakage at reduced pressure differential with both air and water as the test media, with the function media and pressure differential. The simplifying assumptions needed to perform this analys is consistent with the rules in the Code are: 
1. Valve leakage flow area and pressure loss form factor (K) are constant and independent of pressure differential and test media.

2. Valve leakage flow area and pressure loss form factor ( $K$ ) in the reverse flow direction are equal or less than exist in the function flow direction in valves where reverse flow leak testing is allowed by the Code (IWV-3423).

3. In valve leak testing with air, the flow is assumed to be adiabatic. In reality, the flow will be somewhere between adiabatic and isothermal as influenced by heat transfer between the flow boundaries and the air. A refined analysis, including a heat transfer model of the flow path is beyond the scope of this study, and would preclude any generalized formulation.

4. In valve leak testing with liquid, the downstream pressure must be sufficiently above saturation pressure at the prevailing temperature to assure that flashing is suppressed. The vapor generated if flashing were allowed would be detrimental due to two-phase flow losses giving a nonrepresentative leakage rate, and inaccurate measurement of downstream leakage flow due to vapor escape. It is recognized that local flashing will occur at the minimum area if the leakage $p$ ath provides pressure recovery. It is assumed that this flashing has a negligible effect on the leakage flowrate. 
Nomenclature

$P \quad=$ Pressure, psia (absolute)

$V=$ Fluid velocity, $\mathrm{ft} / \mathrm{sec}$

$A=$ Leakage flow area, in. ${ }^{2}$

$K=$ Pressure loss coefficient, dimensionless

$\left(\Delta P=k \times \frac{\rho V^{2}}{2 g \times 144}\right)$

$L=$ Weight flowrate, $1 \mathrm{~b} / \mathrm{hr}$

$Q=$ Volumetric flowrate, gal/min

D = Leak path diameter, in.

$g=$ Gravitational constant $=32.2 \mathrm{ft} / \mathrm{s}^{2}$

$k=$ Gas adiabatic exponent $=1.4$ for air

$R=$ Engineering gas constant $=53.3 \mathrm{ft} /{ }^{\circ} \mathrm{R}$ for air

$T=$ Temperature, ${ }^{\circ} R\left(={ }^{\circ} F+460\right)$

D $\quad=$ Fluid density, $1 \mathrm{~b} / \mathrm{ft}^{3}$

$\Delta P=$ Pressure differential $P_{1}-P_{2}$, psid

$\ell=$ Flow path length, in.

$\mu=$ Fluid viscosity, lb-s/in. ${ }^{2}$

$c=$ Valve seat leakage gap, in.

$\gamma=$ Valve seat radius, in.

$\ell=V_{a}$ lve seat width, in.

\section{Subscripts}

$\begin{aligned} 1 & =\text { Upstream of val: } \because \text { e } \\ 2 & =\text { Downstream of valve } \\ f & =\text { Function, as in plant operation } \\ t & =\text { Test, as in valve leak test } \\ \mathrm{a} & =\text { Air } \\ w & =\text { Water }\end{aligned}$


The expression for water flow through a small restriction is derived below:

$$
\begin{aligned}
& \text { Flow area } A=\frac{\pi 0^{2}}{4} \text { in. } .^{2} \\
& \text { Flow velocity } V=\sqrt{\frac{2 g \Delta P \times 144}{K_{o}}} f^{\prime} . / s \\
& \text { Flowrate } L_{w}={ }_{D A V}=\frac{{ }^{D} w \pi 0^{2} \times 3600}{4 \times 144} \sqrt{\frac{2 g \Delta P \times 144}{K_{\rho_{w}}}} \\
& =\frac{\pi \times 3600 \sqrt{2 g \times 144}}{4 \times 144} D^{2} \sqrt{\frac{\Delta P_{p_{W}}}{K}} \\
& \text { (1) } L_{W}=18910^{2} \sqrt{\frac{\Delta P_{w}}{K}} 10 / \mathrm{hr}
\end{aligned}
$$

Assuming, as previously noted that the leak path characteristics remain constant, $D$ and $K$ in equation ( 1 ) are the same for function and test conditions. The correlation of valve leakage at function conditions with measured leakage at test conditions is given by the expression:

(2) $L_{f}=L_{t} \sqrt{\frac{\Delta f^{D} w-f}{\Delta t^{D} w-t}}$

on a volumetric water flow basis:

$$
Q_{w}=\frac{L}{\rho_{w}} \mathrm{ft} / \mathrm{hr} \times \frac{1}{60} \frac{\mathrm{hr}}{\min } \times 7.18 \frac{\mathrm{gal}}{\mathrm{ft}^{3}}=
$$


(3) $Q_{W}=236 D^{2} \sqrt{\frac{\Delta P}{\rho_{1} K}} \mathrm{gpm}$

Assuming constant values of $D$ and $K$, the correlation of valve leakage at function conditions with measured leakage at test conditions is given by:

$$
Q_{W-f}=Q_{W-t} \sqrt{\frac{\Delta P_{f}^{P} w-t}{\Delta P_{t^{0} W-f}}}
$$

Note, that the volumetric flow correlation (4) has a fluid density factor that is the reciprocal of that factor in the weight flow correlation (2).

Leak Testing with Air

The equations in this section are based on critical air flow which occurs when the ratio of downstream to upstream pressure, $P_{2} / P_{1}$ is less than 0.53 . This restriction simplifies both the equations for flow correlation, and the test procedure since downstream pressure need not be controlled or accurately measured. The equations are derived on the hasis of measuring the upstream volumetric flowrate. This allows the use of a single set of air pressure and temperature measurements. Flow measurement upstream of the valve also precludes the nonconservative error that would occur if the flow was measured downstream, and unknown parallel leakage paths existed out of the downstream volume. The expression for the critical flow of a gas through a restricted flow area $A$ is:

(5) $L_{a}=3600 \sqrt{\frac{g k}{R}\left(\frac{2}{k+1}\right)^{\frac{k+1}{k-1}}} \times \frac{A \times P_{1}}{\sqrt{T_{1}}} \quad \mathrm{lb} / \mathrm{hr} \quad$ a)

a) Ref: Vennard, Elementary Fluid Mechanics, 3rd Edition. 
using ideal gas theory to convert equation (5) to volumetric gas flowrate:

$$
\begin{aligned}
& \rho_{\mathrm{a}-1}=\frac{144 \mathrm{P}_{1}}{\mathrm{RT}_{1}} \quad \mathrm{bb} / \mathrm{ft}^{3} \times \frac{1}{T_{.48}} \mathrm{ft}^{3} / \mathrm{gal}=\frac{19.25 \mathrm{P}_{1}}{R_{1}} \quad \mathrm{~h} / \mathrm{gal}
\end{aligned}
$$

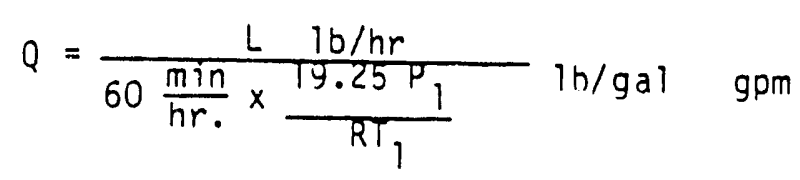

$$
Q=\frac{3600 R T_{1}}{60 \times 19.25 P_{1}} \sqrt{\frac{g k}{R}\left(\frac{2}{k+1}\right)^{\frac{k+1}{K-1}}} \times \frac{A P_{1}}{\sqrt{T_{1}}}
$$

(6) $Q=3.117 \sqrt{g k R\left(\frac{2}{k+1}\right)^{\frac{k+1}{k-1}}} \times \sqrt[A]{T_{1}} \mathrm{gpm}$

noting that: $g=32.2$, and for air $k=1.4, R=53.3 \mathrm{ft} /{ }^{\circ} \mathrm{R}$,

$$
Q_{a}=3.117 \sqrt{32.2 \times 1.4 \times 53.3\left(\frac{2}{2.4}\right)^{6}} \times A T_{1}
$$

(7) $Q_{a}=88.4 \mathrm{~A} \sqrt{T_{1}} \mathrm{gpm}$

since $A=\frac{I I}{4} D^{2}$,

(8) $Q_{a}=69.4 D^{2} \sqrt{T_{1}}$

Introducing the loss factor $K$ is only partially justified since frictional effects downstream of the minimum flow area cannot influence the flowrate when the pressure ratio is significantly less than the critical value of 
0.53. Ignoring this discrepancy, and introducing $k$ in the same relationship to the flow area as exists in the case of liquid flow: (Equation 3)

(9) $Q_{a}=69.4 D^{2} \sqrt{\frac{T_{1}}{K}} \quad \mathrm{gpm}$

For leak-path geometries where $K=1$, the error introduced by different $K$ values for liquid and gas flow are not large since $\sqrt{K}$ applies.

The correlation of function water leakage flowrate with air flowrate leak test data is given by the following expression: (Eqns. 3 and 9)

$$
\frac{Q_{f-w}}{Q_{t-a}}=\frac{236 D^{2} \sqrt{\frac{\Delta P_{f}}{\rho_{w}^{K}}}}{69.4 D^{2} \sqrt{\frac{T_{1-a}}{K}}}
$$

canceling terms and dividing yields:

$$
\frac{Q_{f-w}}{Q_{t-a}}=3.4 \sqrt{\frac{\Delta P_{f}}{\rho_{w}^{\top} 1-a}}
$$

(10) $Q_{f-w}=Q_{t-a} \times 3.4 \sqrt{\frac{\Delta P_{f}}{Q_{w}^{\top} 1-a}}$

\section{Example Calculation}

For typical function and test conditions, assume:

$$
\begin{aligned}
& \Delta P_{f}=2250 \text { psid, } o_{w}\left(100^{\circ} \mathrm{F}, 1125 \mathrm{psia}\right)=62.4 \mathrm{lb} / \mathrm{ft}^{3} \\
& T_{l_{a}}=560^{\circ} \mathrm{R}\left(100^{\circ} \mathrm{F}\right)
\end{aligned}
$$


from Eqn. (10) $\quad Q_{f-w}=Q_{t-a} \times 3.4 \sqrt{\frac{2250}{62.4 \times 560}}$

$$
=Q_{t-a} \times 0.863
$$

For the assumed conditions, critical air flow leakage data closely represents the volumetric water leakage at function conditions.

\section{Laminar Flow}

Assuming that the leakage path approximates a circular duct of diameter 0 , length $\ell$, the expression for the laminar flowrate is:

$$
\text { (ii) } f=\frac{64}{\operatorname{Re}}=\frac{64 u}{\rho D V}=\frac{4 A}{S} \times \frac{\Delta P}{\rho} \times{\frac{2}{V^{2}}}^{\text {(a) }}
$$

for the units in the nomenclature:

$$
\begin{aligned}
& f=\frac{64 \mu \times 12 g}{\frac{\rho}{1728} \times D \times 12 V}=\frac{4 A}{S} \times \frac{\Delta P}{\frac{\rho}{1728}} \times \frac{2}{144 V^{2}} \times 12 g \\
& A=\frac{\pi}{4} 0^{2}, S=\text { surface area }=\pi D_{l} \\
& Q=A \times V \times \frac{60}{231}(\mathrm{gpm}) \\
& \text { (12) } Q=5.31 \times 10^{-4} \frac{D^{4} \Delta P}{4 l} \mathrm{gpm}
\end{aligned}
$$

(a) Through Flow in Annuli, L. N. Tao and W. F. Donovan, Trans. of ASME. November 1955. 
Assuming that the leakage path approximates an annular gap distributed around the valve seat circumference:

$$
\text { for: } \begin{aligned}
c & =\text { valve seat leakage gap, in } \\
r & =\text { valve seat radius, in } \\
x & =\text { valve seat width, in } \\
Q & =\frac{\operatorname{mr} c^{3} \Delta P}{6 \mu l} \frac{i n^{3}}{\mathrm{sec}} \times \frac{60}{231} \frac{\mathrm{gpm}-\mathrm{sec}}{\mathrm{in} .^{3}} \\
\text { (13) } Q & =\frac{0.136 r c^{3} \Delta P}{\mu l} \mathrm{gpm}
\end{aligned}
$$




\author{
INSERVICE TESTING OF VALVES IN \\ NUCLEAR POWER PLANTS \\ SURVEY SHEET
}

NRC TASK \#

6367-4

Please provide the following information:

1. What version, year and addenda, of the ASME Boiler and Pressure Vessel Code, Section XI is implemented for "in-service testing requirements" for your facility?

2. List all "Category A" primary pressure isolation valves in your facility for which the applicable edition and addenda of the ASME Boiler and Pressure Vessel Code, Section XI; Technical Specifications; or NRC orders, require periodic leak testing. Provide valve name, manufacturer, identification number, age, type, and size.

a. Of the valves listed above, provide a history of the in-service leak testing they have received. Provide test medium, test pressure, and leak rates observed. List those valves found to be deficient during testing. Include the number of deficiencies observed for each valve over its service life to date. Describe each deficiency, and the corrective action taken.

b. Of the valves listed in 2. above, list those which at some time during their in-service life to date have missed a required in-service leak test. For each omission, describe the circumstances which caused the leak test to be omitted. 


\section{IN-SERVICE TESTING OF VALVES IN NUCLEAR POWER PLANTS}

SURVEY SHEET - PAGE 2

3. Provide a list and description of the various testing methods utilized to comply with ASME Section XI, as it applies to leak testing of "Category $A$ " valves at your facility. Include sketches of equipment used, together with test piping diagrams, and instrumentation types and locations. Also, include copies of operating procedures used for leak testing, together with examples of logs, records, or other documentation utilized to record the testing data for each valve type.

4. What problems have been encountered in your facility with applicable in-service leak testing requirements and procedures?

a. To what extent has personnel exposure to radiation presented problems in meeting in-service leak testing requirements?

b. Has the availability of personnel qualified to perform in-service leak testing, presented problems or caused in-service leak testing to be delayed?

c. Has component accessibility presented problems in performing in-service-leak testing?

d. Has the original design of the facility, in regard to the availability and location of test taps or orifices, been adequate to allow performance of in-service leak testing?

e. Have documentation requirements been restrictive to an extent you consider unnecessary? Explain.

f. Has in-service leak testing been hindered by the availability of test equipment or procedures?

g. Has interpretation of ASME Section XI presented problems in establishing your in-service leak testing program? 
List and describe any additional problems encountered.

5. List--as a function of valve type, service, size, age, and manufacturer--the allowable leak rate you consider practical from the standpoint of measurement and valve repair.

6. Provide examples of design reports or comparable documentation which delineates the manner in which ASME Sections III and XI code requirements for valves were met at the time of the original installation.

7. Provide examples of applicable portions of Plant Operating Manuals, In-service Inspection Manuals, Technical Specifications, or comparable documentation which outlines in-service leak testing of "Category A" valves in your facility. 


\section{RESPONSE FROM UTILITIES; \\ PRIMARY PRESSURE ISOLATION \\ VALVE LEAK TEST SURVEY}

Note: The attached material was selected from the Utility submittals. Some of the procedures and forms have been omitted to condense this material. The most appropriate information is included. 


\section{T}

Utility A 


\section{INSERVICE TESTING OF VALVES IN \\ NUCLEAR POWER PLANTS \\ SURVEY SHEET}

Please provide the following information:

1. What version, year and addenda of the ASME Boller and Pressure Vessel Code, Section XI is implemented for "In service testing requirements" for your facillty?

ANSWER: 1977 - Summer 1978 Addendum

2. List all "Category A" primary pressure isolation valves in your facility for which your applicable edition and addenda of the ASME Boiler and Pressure Vessel Code, Section XI, requires perlodic leak testing. Provide valve name, manufacturer, identification number, age, type, and size.

NNWER: See attached sheet (Attachment 1)

a. Of the valves listed above, provide a history of the inservice leak testing they have received. Provide test medium, test pressure, and leak rates observed. IIst those valves found to be deficient during testing. Include the number of deficiencies observed for each valve over its service life to date. Describe each deficiency, and the corrective action taken.

ANSWER: See attached sheets (Attachment II)

$\therefore$. Of the valves listed in 2., above, list those which at some time during their in-service life to date have missed a required in-service leak test. For each omission, describe the circumstances which caused the leak test to be omitted.

ANSWER: As of $9 / 25 / 81$ no valve 11 sted has missed a required In-service leak test.

3. Provide a list and description of the varlous testing methods utilized to comply with ASME Section XI, as it applies to leak testing of "Category A" valves at your facility. Include sketches of equipment used, together with test piping diagrams, and instrumentation types and location. Also, include coples of operating procedures used for leak testing, together with examples of logs, records, or other documentation utilized to record the testing data for each valve type.

ANSWER: See attached sheets (Attachment III) 
4. What problems have been encountered in your facility with applicable in-service leak testing requirements and procedures?

ANSWER: According to Utility A Technical Specification 3.4.\%.2.f each Reactor Coolant System Pressure Isolation Valve has a leakage limit of 1 GPM at a Reactor Coolant System pressure of $2235+$ 20 psig. And since other Tech. Specs. require us to test valves at pressures as low as $350 \mathrm{psig}$, our acceptance criteria becomes .4 GPM (according to IWV-3423: Differential Test Pressure Leak Testing). This criteria is ifficult to meet with temperature and pressure fluctuations over long lengths of plping.

a. To what extent has personnel exposure to radiation presented problems in meeting in-service leak testing requirements?

ANSWER: Under present start-up conditions, exposure has not been a problem yet.

b. Has the avallabllity of personnel qualified to perform in-service leak testing presented problems or caused in-service leak testing to be delayed?

ANSWER: Due to varying Tech. Specs. this test will always be critical path during heatup, and under present staffing conditions only one person is in charge of this test which makes lengthy testing, especially testing involving repalrs to valves, very difficult.

c. Has component accessibility presented problems in performing in-service leak testing?

ANSWER: Since testing is done from a centralized location, this has not been a problem.

d. Has the original design of the facility, in regard to the avaliablifty and location of test taps or orffices, been adequate to allow performance of in-service leak testing?

ANSWER: Due to extensive modifications during construction of the plant and some modifications to better meet Tech. Spec. 4.4.7.2.2.d, we have changed a large portion of the plant's original design to accommodate this test.

e. Has time been avaflable to allow the plant to cool down sufficiently to permit in-service leak testing to be performed?

ANSWER: Due to Tech. Spec. 4.4.7.2.2.d, most testing is done during plant heat-up which means temperature (1.e., water flashing to steam) has been a problem. 
f. Have documentation requirements been restrictive to an extent you consider unnecessary? Expla1n.

ANSWER: Documentation has been no more restrictive on this test than any other testing done at the plant.

g. Has in-service leak testing been hindered by the availability of test equipment or procedures?

ANSWER: No more so than any other testing.

h. Has interpretation of ASME Section XI presented problems in establishing your in-service leak testing program?

ANSWER: No

List and describe any additional problems encountered.

5. List -- as a function of valve type, service, size, age, and manufacturer-the allowable leak rate you consider practical from the standpoint of measurement and valve repair.

ANSWER: We base our acceptable leakage rate on Tech. Spec. 3.4.7.2.f ( 1 GPM at $2235 \pm 20$ psig)

6. Provide examples of design reports or comparable documentation which delineates the manner in which ASME Sections III and XI code requirements for valves were met at the time of the original installation.

ANSWER: See attached sheets (Attachment IV)

7. Provide examples of applicable portions of Plant Operating Manuals, Inservice Inspection Manuals, or comparable documentation which outlines in-service leak testing of "Category $A$ " valves in your facility.

ANSWER: See attached sheets (Attachment V) 
Attachment 1

Category A Primary Pressure Isolation Valves

Name

Accumulator Discharge Accumulator Discharge Accumulator Discharge Accumulator Discharge Accumulator Discharge Accumulator Discharge Accumulator Discharge Accumulator Discharge Safety Injection (Hot Leg) Safety Injection (Hot Leg) Safety Injection (Hot Leg) Safety Injection (Hot Leg) Safety Injection (Hot Leg) Safety Injection (Hot Leg) Safety Injection (Hot Leg) Safety Injection (llot Leg) Safety Injection/RHR (Cold Leg) Safety Injection/RHR (Cold Leg) Safety Injection/RHR (Cold Leg) Safety Injection/RHR (Cold Leg) Safety Injection/RHR (Cold Leg) Safety Injection/RHR (Cold Leg) Safety Injection/RHR (Cold Leg) Safety Injection/RHR (Cold Leg) Upper Head Injection Upper Head Injection Upper Head Injection Upper Head Injection Upper Head Injection Upper Head Injection RHR

RHR

\begin{tabular}{|c|c|}
\hline lanufacturer & I.D. \# \\
\hline Walworth & 1NI059 \\
\hline Walworth & 1 NI060 \\
\hline Walworth & 1 NI070 \\
\hline Walworth & 1NI071 \\
\hline Walworth & 1NI081 \\
\hline Walworth & 1NI082 \\
\hline Walworth & 1NI093 \\
\hline Walworth & 1NI094 \\
\hline Kerotest & 1 NI 124 \\
\hline Halworth & $1 N I 126$ \\
\hline Kerotest & 1 NII 28 \\
\hline Walworth & $1 \mathrm{NI} 134$ \\
\hline Kerotest & $1 N I 156$ \\
\hline Walworth & $1 \mathrm{NI} 157$ \\
\hline Kerotest & $1 N I 159$ \\
\hline Walworth & $1 N I 160$ \\
\hline Kerotest & $1 N I 165$ \\
\hline Kerotest & INI 167 \\
\hline Kerotest & $1 N I 169$ \\
\hline Kerotest & $1 N I 171$ \\
\hline Walworth & $1 N I 175$ \\
\hline Walworth & INI 176 \\
\hline Walworth & INI 180 \\
\hline Walworth & INI 181 \\
\hline West1nghouse & INI 248 \\
\hline Westinghouse & $1 N I 249$ \\
\hline Westinghouse & $1 N I 250$ \\
\hline Westinghouse & $1 N I 251$ \\
\hline Westinghouse & 1NI252 \\
\hline Westinghouse & $1 N I 253$ \\
\hline Walworth & $1 \mathrm{NDOO1E}$ \\
\hline Valworth & 1ND002A \\
\hline
\end{tabular}

Type Size (inches)

CK 10

CK 10

CK 10

CK 10

CK 10

CK 10

CK 10

CK 10

CK 2

CK 6

CK 2

CK 6

CK 2

CK 6

CK 2

CK 2

CK 2

$\mathrm{CK} 2$

CK 2

CK 2

CK 6

CK 6

CK 6

CK 6

CK 12

CK 12

CK 8

CK 8

CK 8

CK 8

GT 14

GT 14 
1) During all pressure testing of primary pressure 1solation valves, water is used as a test medium.

2) The test pressure used for each valve is listed in the test procedure (Attachment III).

3) When we tested all the primary pressure 1solation valves for the first time, there were many fallures. These failures continued until maintenance and Walworth representatives perfected lapplng and bluing procedures to the point that the valves would pass the leak test. Some of the leakages found prior to malntenance were:

\begin{tabular}{llll} 
Valve \# & Leakage & Valve & Leakage \\
\cline { 3 - 3 } INI60 & $2.4 \mathrm{GPM}$ & 1NI71 & $4.8 \mathrm{GPM}$ \\
INI59 & $1.5 \mathrm{GPM}$ & 1NI70 & $4.5 \mathrm{GPM}$ \\
INI82 & $5.4 \mathrm{GPM}$ & INI81 & $>10 \mathrm{GPM}$ \\
INI93 & $2.1 \mathrm{GPM}$ & INI159 & $9.4 \mathrm{GPM}$ \\
INI156 & $8.6 \mathrm{GPM}$ & INI160 & $2 \mathrm{GPM}$ \\
INI157 & $1.1 \mathrm{GPM}$ & 1NI248 & $>10 \mathrm{GPM}$ \\
INI124 & $4.7 \mathrm{GPM}$ & INI169 & $2.1 \mathrm{GPM}$
\end{tabular}

After the initial leak testing and subsequent maintenance which caused about $1 / 3$ of the failed valves to pass, it was decided that all falled valves would be worked on using the new lapping techniques and a local leak testing arrangement (shown below).

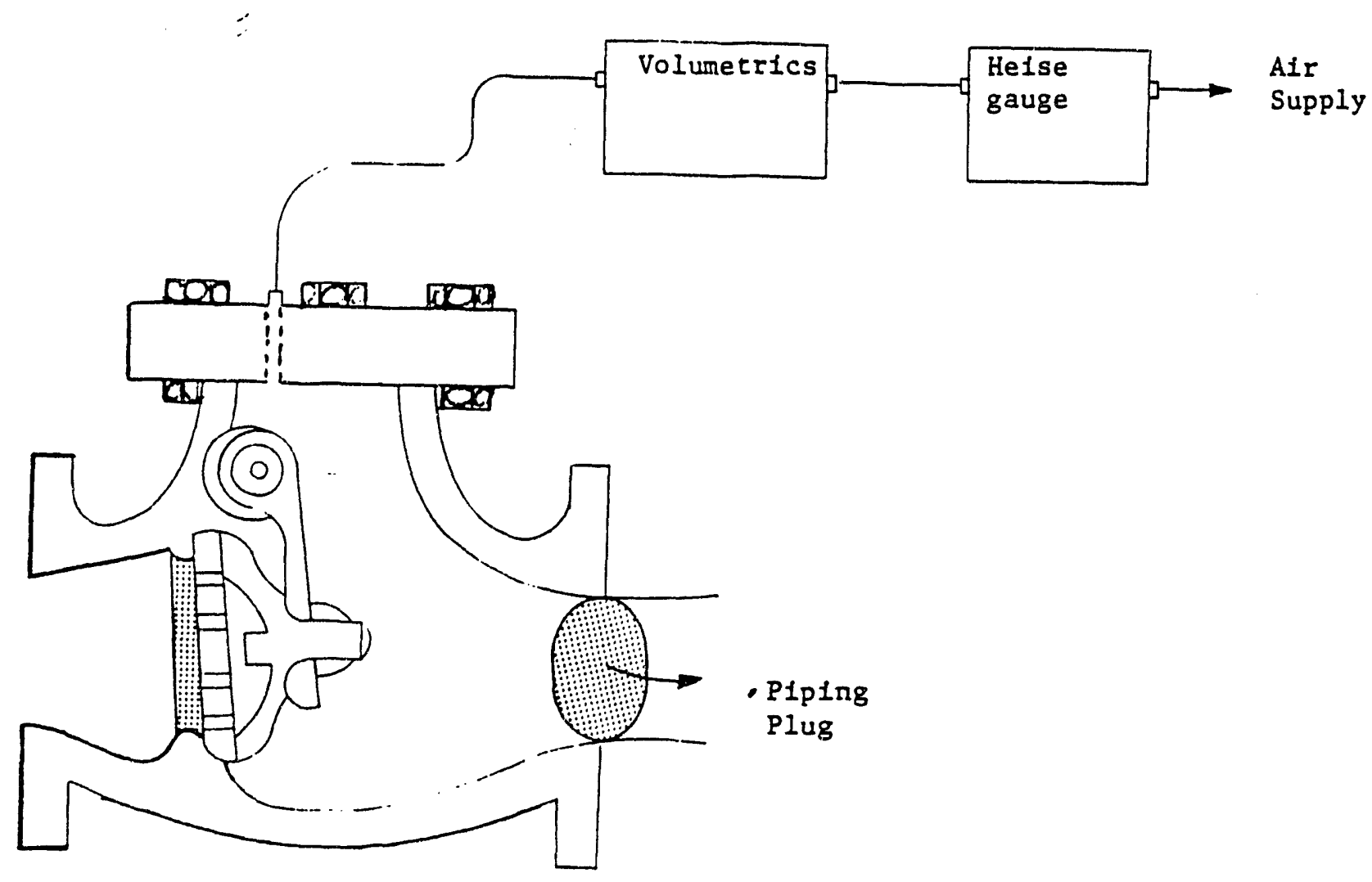


The volumetric and Helse gauge assembly measure the amount of make up air it takes to maintain a certain pressure (i.e., the leakage). We set an acceptance of .1 GPM at 20 psig of air. The work done on the valves required an unscheduled outage of approximately 3 weeks. Since this work was only done 4 months ago (approximately 6/1/81) we have not been able to determine how time and use will affect the leak rate. 
Currently at Utility $A$ we are using two methods to test primary pressure isolation valves.

Method 1:

For : ost valves we have Installed a "test header" which routes any leakage to a standpipe. The leakage is measured by a rise in level in the standpipe.

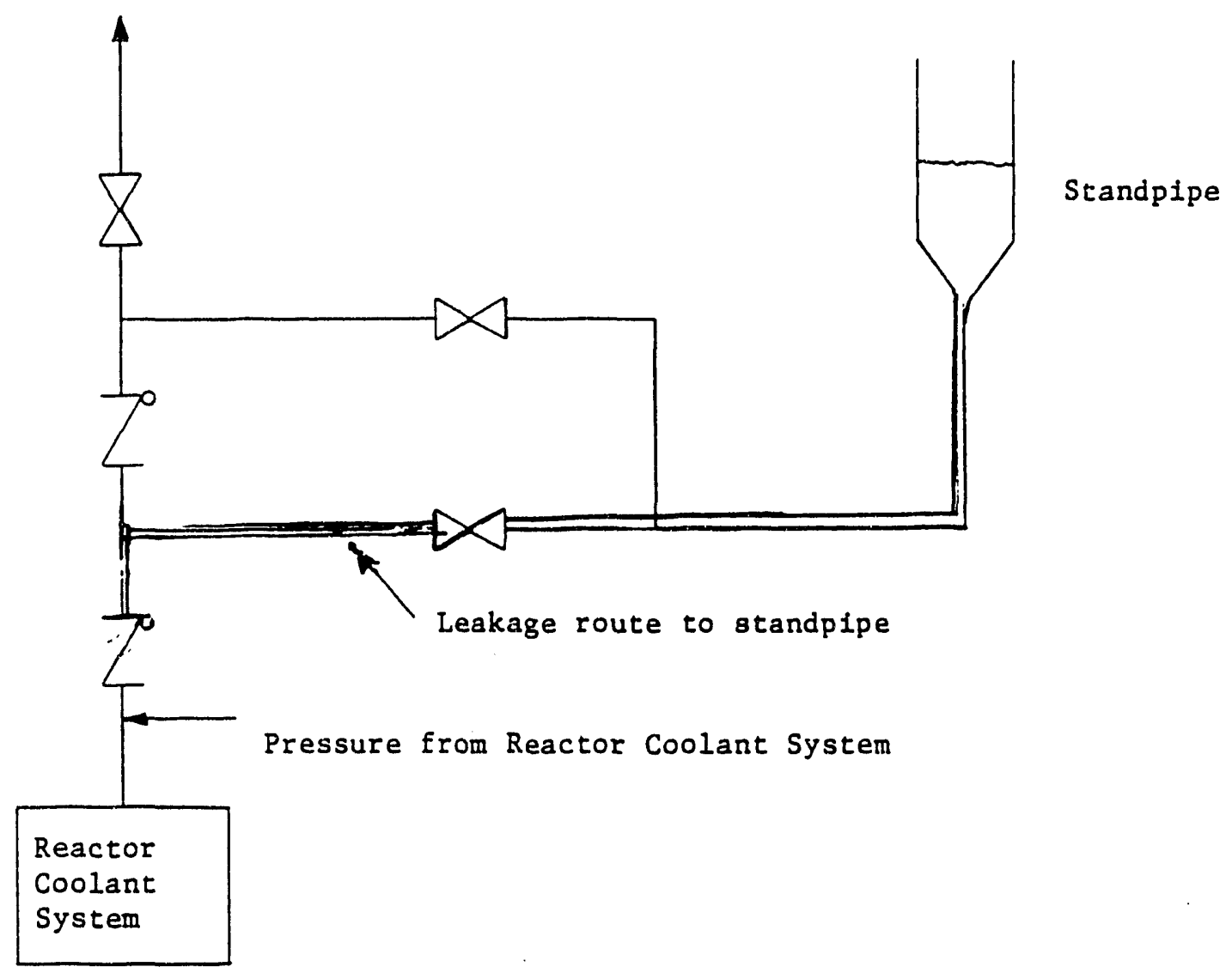

The level of the standpipe is determined by a differential pressure indication between the top and bottom of the pipe.

Method 2:

For the 4 primary Upper Head Infection check valves we measure leakage by:

1) Vent downstream slde of check valves to atmosphertc pressure.

2) Run Reactor Coolant System Inventory'Calc. to find total leakage from Reactor Coolant System.

3) Attribute all leakage to the check valves being tested. 
Utility B 
October 26,1981

John G. Collett

FG\&G Idaho Inc.

Idaho National Engineering Laboratory

Idaho Falls, ID 83401

Dear John,

Enclosed is a copy of our Containment Isolation Valve Leak Rate Test procedure that you requested.

The following information is in response to your survey sheet and is numbered accordingly.

1. ASME Section XI 1977 S-78 addenda.

2. Valves that are leak rate tested are listed in enclosed procedure. Time does not permit me to obtain the information required by parts (a) and (b) of this question. This information is available on LER's submitted to the NRC.

3. Methods used are in accordance with 10 CFR 50, Appendix $J$ and the enclosed procedures.

4. (a) None.

(b) No.

(c) See exemptions.

(d) See exémptions for FWCI, RBCCW and Fuel Pool.

(e) Yes.

(f) No.

(g) No.

(h) Definition of "ALERT" and "REQUIRED ACTION" ranges for pump vibration signature analysis.

5. Time does not permit me to fully answer this question. See acceptance criteria in procedure.

6. Section XI was not issued at time of original construction.

7. See plant ISI manual and applicable procedures.

Sincerely yours, 
Utility C 


\section{INSERVICE TESTING OF VALVES IN \\ NUCLEAR POWER PLANTS}

SURVEY SHEET
NRC TASK 非 6367-4

The following information is provided in response to the survey questions.

1. Question:

What version, year and addenda, of the ASME Boiler and Pressure Vessel Code, Section XI is implemented for "in service testing requirements" for your facility?

\section{Response:}

Utility C Nuclear Plant Unit I Pump and Valve Program is in accordance with the requirements of Subsections IWP and IWV of the ASME Boiler and Pressure Vessel Code, Section XI, 1974 Edition through the Summer 1975 Addenda .

\section{Question:}

List all "Category A" primary pressure isolation valves in your facility for which the applicable edition and addenda of the ASME Boiler and Pressure Vessel Code, Section XI; Technical Specifications; or NRC orders, require periodic leak testing. Provide valve name, manufacturer, identification number, age, type and size.

\section{Response:}

See Tablé 1 .

\section{Question:}

a. Of the valves listed above, provide a history of the in-service leak testing they have received. Provide test medium, test pressure, and leak rates observed. List those valves found to be deficient during testing. Include the number of deficiencies observed for each valve over its service life to date. Describe each deficiency, and the corrective action taken.

\section{Response:}

See Table 2.

\section{Question:}

b. Of the valves listed in 2., above, list those which at some time during their in-service life to date have missed a required in-service leak test. For each omission, desfribe the circumstances which caused the leak test to be omitted. 


\section{Response:}

None of the valves listed in Table 1 have missed a required inservice leak test.

\section{Question:}

Provide a list and description of the various testing methods utilized to comply with ASME Section XI, as it applies to leak testing of "Category $A^{\prime \prime}$ valves at your facility. Include sketches of equipment used, together with test piping diagrams, and instrumentation types and locations. Also, include copies of operating procedures used for leak testing, together with examples of logs, records, or other documentation utilized to record the testing data for each valve type.

\section{Response:}

See the attached Plant Procedure, FNP-1-STP-158, Reactor Coolant System Pressure Isolation Valve Leak Test, and piping diagrams D-175037 sheet $1, \mathrm{D}-175038$ sheet $1, \mathrm{D}-175038$ sheet 2 .

\section{Question:}

What problems have been encountered in your facility with applicable in-service leak testing requirements and procedures?

a. To what extent has personnel exposure to radiation presented problems in meeting in-service leak testing requirements?

\section{Response:}

Personnel exposure to radiation does not present any unusual problems during performance of the leak testing. However, significant radiation exposure to personnel has been a problem during valve repair. A radiation dose of approximately 8 REM was accumulated by personnel during repair

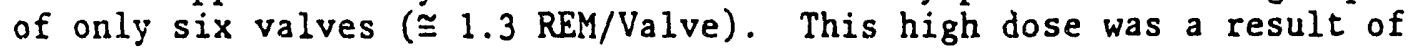
exposing the valve internals which are highly contaminated. The surface exposure of the valve internals and valve bodies averaged between 20 to $30 \mathrm{REM} / \mathrm{hr}$. The total dose for the testing and repair was $9 \mathrm{REM}$.

\section{Question:}

b. Has the availability of personnel qualified to perform in-service leak testing, presented problems or caused in-service leak testing to be delayed?

\section{Response:}

No.

\section{Question:}

c. Has component accessibility presented problems in performing in-service leak testing? 


\section{Response:}

Yes, the system alignment necessary to perform the leak testing is difficult to accomplish when considering operational constraints because, the test alignment deviates significantly from the normal operational alignment.

\section{Question:}

d. Has the original design of the facility, in regard to the availability and location of test taps or orifices, been adequate to allow performance of in-service leak testing?

\section{Response:}

Yes, the availability of test vents and drains have been adequate when performing leak tests per the plant procedure.

\section{Question:}

e. Have documentation requirements been restrictive to an extent you consider unnecessary? Explain.

\section{Response:}

No, the documentation requirements are per plant procedure.

\section{Question:}

f. Has in-service leak testing been hindered by the availability of test equipment or procedures?

Response:

No.

Question:

8. Has interpretation of ASME Section XI presented problems in establishing your in-service leak testing program?

\section{Response:}

There have been no problems with interpreting ASME Section XI when establishing the inservice leak testing program.

However, there are problems determining which valves the Section XI Category A requirements apply to when establishing the pressure isolation valves. Section XI does not provide sufficient guidance for these valves. This information has been derived from the NRC staff position stated in NUREG-0677 and Appendix A to the Proposed Revision Standard Review Plan PSRP-3.9.6 (Rev. 2).

\section{Question:}

List and describe any additional problems encountered. 


\section{Response:}

Additional problems have been encountered when performing the leak testing just prior to resuming power operation as the plant is pressurized. If a valve fails, the plant has to depressurize and drain the Reactor Coolant System to mid-plane to perform valve repair. As a result, the plant has been subjected to unnecessary transients and has an unscheduled extension of the outage.

It would be more practical to perform the leak testing when the plant is being depressurized at the start of the outage. Then the valves that fail could be scheduled to be repaired during the outage and retested at the end of the outage. The valve integrity and leak-tightness will be verified whether it has been tested at the beginning or end of the outage.

5. Question:

List -- as a function of valve type, service, size, age and manufacturer -the allowable leak rate you consider practical from the standpoint of measurement and valve repair.

\section{Response:}

The current leakage rate limits as shown in the attached Technical Specifications, Table 4.4-3, are acceptable for all valves.

\section{Question:}

Provide examples of design reports or comparable documentation which delineates the manner in which ASME Sections III and XI code requirements for valves were met at the time of the original installation.

\section{Response:}

See the attached example of Form N-5 Data Report for Field Installation of Nuclear Power Plant Components, Component Supports and Appurtenances and Form NIS-1 Owner's Data Report tor Inservice Inspection for ASME Section III and XI requirements, respectively.

\section{Question:}

Provide examples of applicable portions of Plant Operating Manuals, Inservice Inspection Manuals, Technical Specifications, or comparable documentation which outlines in-service leak testing of "Category A" valves in your facility.

\section{Response:}

See the plant procedure FNP-1-STP-158 (response to Question 3), the attached Technical Specification and the example page from the FNP Unit 1 Pump and Valve Program. 
TABLE 1

GENERAL INFORMATION

\begin{tabular}{|c|c|c|c|c|}
\hline $\begin{array}{l}\text { VALVE } \\
\text { ID NUMBER }\end{array}$ & VALVE FUNCTION & MANUFACTURER & SIZE \& TYPE & $A G E \div$ \\
\hline Q1E11V021A & $\begin{array}{l}\text { RHR Pump Discharge } \\
\text { to SICL }\end{array}$ & Velan & 6" Check Valve & $4 \mathrm{Yrs}$ \\
\hline Q1E11V021B & $\begin{array}{l}\text { RHR Pump Discharge } \\
\text { to SICL }\end{array}$ & Velan & 6" Check Valve & $4 \mathrm{Yrs}$ \\
\hline Q1E11V021C & $\begin{array}{l}\text { RHR Pump Discharge } \\
\text { to SICL }\end{array}$ & Velan & 6" Check Valve & 4 Yrs \\
\hline Q1E11V051A & $\mathrm{SI} / \mathrm{BIT}$ to $\mathrm{RCS}(\mathrm{CL})$ & Velan & $\begin{array}{l}6 " 1500 \text { lb } \\
\text { Check Valve }\end{array}$ & 4 Yrs \\
\hline Q1E11V051B & SI/BIT to RCS (CL) & Velan & $\begin{array}{l}6 " 1500 \text { lb } \\
\text { Check Valve }\end{array}$ & 4 Yrs \\
\hline Q1E11Vu51C & SI/BIT to RCS (CL) & Velan & $\begin{array}{l}6 " 1500 \text { lb } \\
\text { Check Valve }\end{array}$ & $4 \mathrm{Yrs}$ \\
\hline Q1E21V062A & SIS/BIT to RCS (CL) & Kerotest & 2" Check Vaíve & 4 Yrs \\
\hline Q1E21V062B & SIS/BIT to RCS (CL) & Kerotest & 2" Check Valve & $4 \mathrm{Yrs}$ \\
\hline Q1E21V062C & SIS/BIT to RCS (CL) & Kerotest & 2" Check Valve & 4 Yrs \\
\hline Q1E21V066A & $\begin{array}{l}\text { CHG (HHSI) Pumps } \\
\text { Disch to RCS (CL) }\end{array}$ & Kerotest & 2" Check Valve & $4 \mathrm{Yrs}$ \\
\hline Q1E21V066B & $\begin{array}{l}\text { CHG (HHSI) Pumps } \\
\text { Disch to RCS (CI) }\end{array}$ & Kerotest & 2" Check Valve & 4 Yrs \\
\hline Q1E21V066C & $\begin{array}{l}\text { CHG (HHSI) Pumps } \\
\text { Disch to RCS (CL) }\end{array}$ & Kerotest & 2" Check Valve & 4 Yrs \\
\hline Q1E21V076A & $\begin{array}{l}\text { Water from Residual } \\
\text { Hx to SI to RCS HL } \\
\text { Loops } 1 \& 2\end{array}$ & Velan & 6" Check Valve & 4 Yrs \\
\hline Q1E21V076B & $\begin{array}{l}\text { Water from Residual } \\
\text { Hx to SI to RCS HL } \\
\text { Loops } 1 \& 2\end{array}$ & Velan & 6" Check Valve & $4 \mathrm{Yrs}$ \\
\hline Q1E21V077A & $\begin{array}{l}\text { HHSI/LHSI and RHR to } \\
\text { RCS HL Loops } 1 \& 2\end{array}$ & Velan & 6" Check Valve & 4 Yrs \\
\hline Q1E21V077B & $\begin{array}{l}\text { HHSI/LHSI and RHR to } \\
\text { RCS HL Loops } 1 \& 2\end{array}$ & Velan & 6" Check Valve & 4 Yrs \\
\hline
\end{tabular}

*Age Based on commercial operation date of December 1, 1977 
TABLE 2

TESTING HISTORY†

\begin{tabular}{|c|c|c|c|c|c|}
\hline \multirow[b]{2}{*}{$\begin{array}{c}\text { VALVE } \\
\text { ID NUMBER }\end{array}$} & \multicolumn{2}{|c|}{$\begin{array}{c}\text { FIRST TEST } \\
11 / 7 / 80-11 / 10 / 80\end{array}$} & \multicolumn{2}{|c|}{$\begin{array}{c}\text { SECOND TEST } \\
2 / 27 / 81-2 / 28 / 81 \\
\end{array}$} & $\begin{array}{c}\text { THIRD TEST } \\
3 / 20 / 81 \\
\end{array}$ \\
\hline & $\begin{array}{l}\text { TEST } \\
\text { PRESSURE }\end{array}$ & LEAKAGE & $\begin{array}{l}\text { TEST } \\
\text { PRESSURE }\end{array}$ & LEAKAGE & $\begin{array}{ll}\text { TEST } & \\
\text { PRESSURE LEAKAGE }\end{array}$ \\
\hline Q1EIIV021A & 400 PSIG & $0.1 \mathrm{GPM}$ & & & \\
\hline Q1E11V021B & 325 PSIG & $6 \mathrm{GPM}^{*}$ & 340 PSIG & None & \\
\hline Q1E11V021C & 400 PSIG & $0.1 \mathrm{GPM}$ & & & \\
\hline Q1E11V051A & 400 PSIG & $8.9 \mathrm{GPM} *$ & 390 PSIG & 9.1 PSIG* & 1025 PSIG $0.9 \mathrm{GPM}$ \\
\hline Q1E11V051B & 400 PSIG & None & & & \\
\hline Q1E11V051C & 400 PSIG & $3.3 \mathrm{GPM}$ & 390 PSIG & $2.9 \mathrm{GPM}$ & \\
\hline Q1E21V062A & 400 PSIG & $0.1 \mathrm{GPM}$ & & & \\
\hline Q1E21V062B & 400 PSIG & $0.1 \mathrm{GPM}$ & & & \\
\hline Q1E21V062C & 400 PSIG & $0.1 \mathrm{GPM}$ & & & \\
\hline Q1E21V066A & 400 PSIG & $0.1 \mathrm{GPM}$ & & & \\
\hline Q1E21V066B & 400 PSIG & $0.1 \mathrm{GPM}$ & & & \\
\hline Q1E21V066C & 400 PSIG & $0.1 \mathrm{GPM}$ & & & \\
\hline Q1E21V076A & 900 PSIG & None & 340 PSIG & None & \\
\hline Q1E21V076B & 900 PSIG & None & 340 PSIG & None & \\
\hline Q1E21V077A & 1054 PSIG & $6 \mathrm{GPM}^{*}$ & 375 PSIG & None & \\
\hline Q1E21V077B & 1054 PSIG & 3 GPM & 375 PSIG & None & \\
\hline
\end{tabular}

TTest Medium - Water

HIndicates tests which failed due to excessive leakage. Valves were repaired by lapping the disks. 


\section{UTILITY C \\ SURVEILLANCE TEST PROCEDURE \\ STP-158 \\ REACTOR COOLANT SYSTEM PRESSURE \\ ISOLATION VALVE LEAK TEST}

1.0 Objective

To verify that the backleakage for the following check valves meet the Acceptance criteria listed below:

Q1E21V077A and B - Hot Leg Injection Check Valves

Q1E2IV076A and B - Hot Leg Injection Check Valves

QIEIIV05IA, B and C - Cold Leg Injection Check Valves

Q1ElIV021A, B and C - Cold Leg Injection Check Valves

Q1E21V062A, B and C - Cold Leg Injection Check Valves

Q1E21V066A, B and C - Cold Leg Injection Check Valves

1.1 Leakage rates less than or equal to $1.0 \mathrm{gpm}$ are considered acceptable. However, for initial testing and testing foliowing repair, leakage rates of less than or equal to $5 \mathrm{gpm}$ are considered acceptable.

1.2 Leakage rates greater than $1.0 \mathrm{gpm}$ but less than or equal to $5.0 \mathrm{gpm}$ are considered acceptable if the latest measured rate has not exceeded the rate determined by the previous test by an amount that reduces the margin between the measured leakage rate and the maximum permissible rate of $5.0 \mathrm{gpm}$ by $50 \%$ or greater.

1.3 Leakage rates greater than $1.0 \mathrm{gpm}$ but less than or equal to $5.0 \mathrm{gpm}$ are considered unacceptable if the latest measured rate exceeded the rate determined by the previous test by an amount that reduces the margin between measured leakage rate and the maximum permissible rate of $5.0 \mathrm{gpm}$ by $50 \%$ or greater.

1.4 Leakage rates greater than $5.0 \mathrm{gpm}$ are considered unacceptable.

2.0 References

2.1 Standard Review PIan (Proposed Revision) PSRP-3.9.6.

2.2 D-175037, sheet 1 of 3 - Reactor Coolant system.

$2.3 \mathrm{D}-175038$, sheets 1 and $2^{\circ}$ of 3 - Safety Injection system. 


\subsection{Test Equipment}

3.1 Test rig as shown below or comparable.

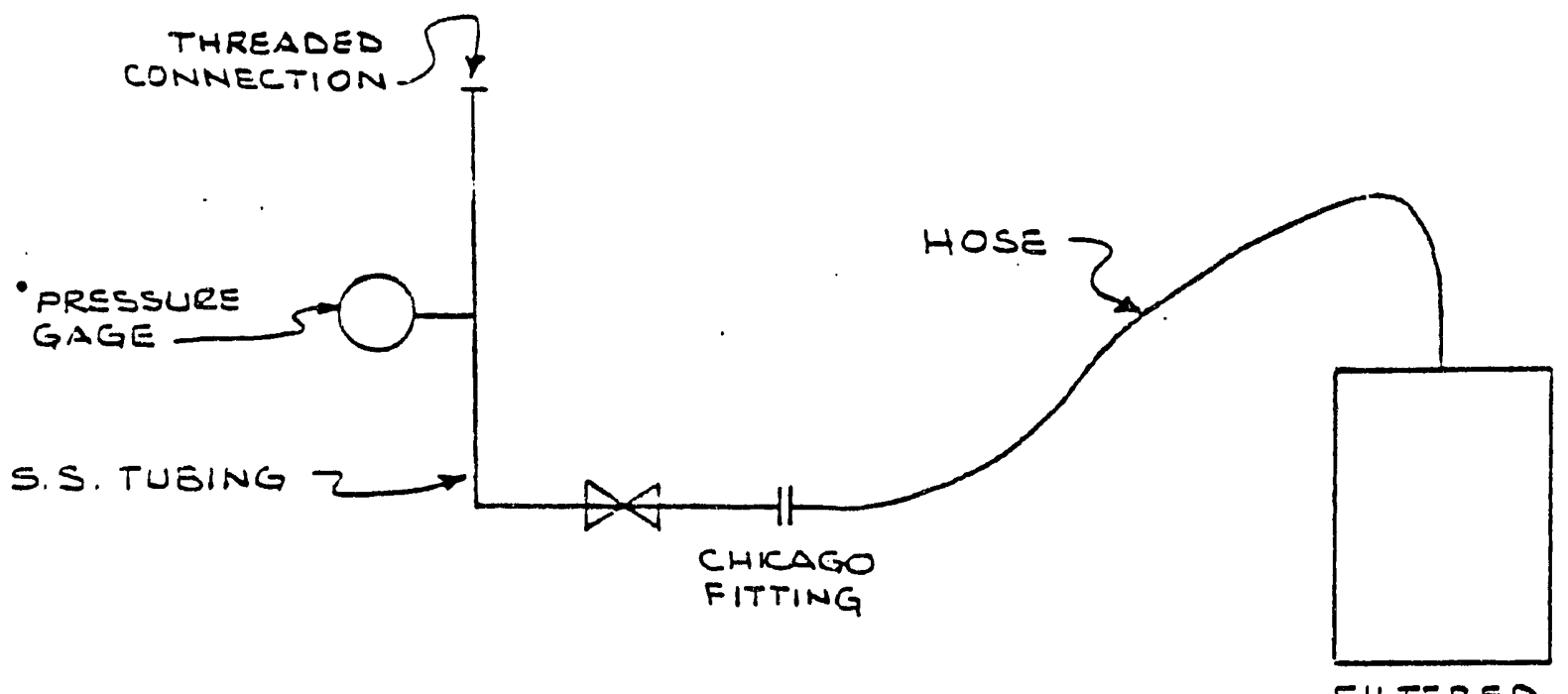

COLLECTION BOTTLES

3.2 Portable Hydro Pump.

3.3 Large graduated filtered collection bottles from Health Physics.

3.4 Stopwatch.

4.0 Required Data \& Documentation

4.1 An Official Test Copy of the completed test procedure, along with data collected, will be retained by Document Control as part of the plant historical record.

\subsection{Prerequisites \&. Initial Conditions}

5.1 Obtain Health Physics approval to enter required test areas.

5.2 One or both trains of RHR shall be out of service for testing check valves vosiA, B, C, V062A, B, C. V066A, B, C\& V021A, B, C. 


\section{Precautions and Notes}

6.1 When making connections to vent and drain valves or operating vent and drain valves, all reasonable care should be exercised to prevent personnel injury from an accidental discharge of steam or hot water.

6.2 When a tygon hose is run to a bucket or beaker to collect back leakage through a check valve, label the container with th number of the check valve for which the leakage is bein collected, if the container is not in the immediate vicinity of the check valve.

6.3 Use only demineralized water as a source of water to the hydro pump in this procedure.

6.4 Leak tests may be performed at pressures less than 2235 psi, but data obtained will be adjusted in accordance with ASME Section XI, IWV-3420 section $\mathrm{C}-5$.

6.5 Before engaging hydro pumps, obtain the Reactor Coolant system Pressure from the Control Room, and ensure hydro pump pressure is at least 100 psi below it at all times.

6.6 When plant is solid maintain constant communication with Control Room during testing to monitor for loss of RCS pressure due to leakage collection and/or increase in RCS pressure due to overpressurization from hydro pump.

6.7 Valve leak tests may be worked out of procedural order at the discretion of the Test Director.

7.0 Detailed Test Procedure

7.1 Determine check valve back leakage of the hot leg injection line check valves QlE2IV077A \& Q1E2IV077B using Reactor Coolant system Pressure.

7.1.1 Verify closed or close valves Q1EIIV044(8889) QIE2IV068(8886) and Q1E2IV072(8884). Install test rig (described in section $3.0)$ to test connection valve QV422C, QV412D or QV411D for QV077A and valve QV422D, QV412E or QV4IIE for QV077B. Test connection valve will be selected in field by test director or his designated alternate. 
7.1.2 Connect high pressure tubing to test rig and run to filtered collection bottle provided by HP \& located at a convenient point above the highest point in the line containing subject check valve(s). 7.I.3 Fill high pressure tubing with demin.
water.

7.1.4 With all valves in the test rig closed, slowly open test connection valve. Observe test gauge.

7.1 .4 .1

If no pressure is indicated, continue observing gauge for several more minutes. If still no pressure is indicated, REv. check valve can be assumed functioning satisfactorily. Close test connection valve and restore system.

7.1.4.2 If pressure is indicated, it is quite possibly residual pressure in the Iine, and not pressure due to a leaking valve.
a. Carefully attempt to bleed off pressure.
b. After bleed off, if no appreciable pressure build up is noted, go to step 7.1.4.1.
c. If pressure remains unchanged or builds back up after bleed off, check valve leak test shall be performed to determine valve acceptability.
NOTE: If after the bleed off attempt a high pressure is indicated, the check valve may be assumed to be functioning unsat- isfactorily. At the discretion of the test director, 


$\begin{array}{lll}7.1 .5 \quad \text { Check valve leak rate test. } & \begin{array}{c}\text { the check valve } \\ \text { leak test may then } \\ \text { be waived and the } \\ \text { the valve tagged } \\ \text { for repair. }\end{array} \\ 7.1 .5 .1 \quad \begin{array}{l}\text { Slowly open test connection } \\ \text { valve. }\end{array} & \begin{array}{l}\text { When flow of water into collection } \\ \text { bottle stabilizes, begin } \\ \text { measuring the leak rate. }\end{array} \\ 7.1 .5 .5 & \begin{array}{l}\text { Record the time duration and } \\ \text { amount of leakage collected. }\end{array} & \text { Rev. } \\ 7.1 .5 .4 & \begin{array}{l}\text { shut test connection valve. } \\ 7.1 .5 .6\end{array} & \begin{array}{l}\text { Drain \& remove high pressure } \\ \text { hose and test rig. } \\ \text { Restore system. }\end{array}\end{array}$

7.2 Determine check valye back leakage of hot leg injection line check valves Q1E2IV076A and QIE21V076B.

7.2.1 Verify close or close valves Q1E11V044(8889), Q1E2IV068(8886) and Q1E21V072(8884).

7.2.2 Install test rig to test connection valve QIEIIV048E.

7.2.3 Connect high pressure tubing to test rig and run to filtered collectoin bottle provided by HP and located at a convenient point above the hot leg injection line.

7.2.4 Connect hydro pump(s) to vent or drain valves used as test connections in 7.1.1. Hydro pump pressure shall be maintained at a minimum of 100 psi less than Reactor Coolant system pressure for the test duration. Hydro pump pressure shall be noted on leak test data sheet.

7.2.5 Perform leak tests per sections 7.1 .3 through 7.1 .5 .

NOTE: Collection of leakage for both vaives will be taken simultaneously 
from the same point. Although leakage is being collected from two valves, the maximum allowable leakage rate at this point is still 1 GPM.

\subsubsection{Disconnect hydro pumps.}

7.3 Determine check valve back leakarge of the cold leg injection line check valves Q1EIIV05IA \& B using Reactor Coolani system pressure.

7.3.1 Verify closed or close valves Q1E21V063(8885), Q1E21V004A \& B (8801A \& B), Q1EIIV023B(8888B) and Q1EIIV043A(8972A). Before closing V023B(8888A), verify Q1E1IV024A \& $B$ $(8887 A \& B)$ open, then turn off RHR A Train pump.

7.3.2 Install test rigs (described in section $3.0)$ to test connection valve gV061B or QV415D for QV051A, QV0548 or QV415E for QV051B. Test connection valve will be selected in field by Test Director or his designated alternate.

\subsubsection{Perform leak tests per sections 7.1 .2} through 7.1.5.

7.4 Determine check valve back leakage of the cold leg injection line check valves Q1EIIV021A \& B, Q1E21V062A \& B \& Q1E2IV066A\& B.

7.4.1 Verify closed or close valves Q1E21V063(8885), Q1E21V004A \& B (8801A \& B) Q1EIIV023B(8888A), and Q1EIIV043A(8972A). Before closing V023B (8888A), verify Q1E1IV024A \& B $(8887 A \& B)$ open, then turn off RHR A Train pump.

7.4.2 Install test rigs (described in section $3.0)$ to test connection valve Q1EIIV049D, V07713, VO6OB or V072B for QV021A \& B, QV558B or QV416B for QV062A \& $B$ and QV418B for QV066A \& B. Test connection valves will be selected in field by Test Director or his designated alternate.

7.4.3 Connect hydro pump(s) to vent and/or drain valves used as test connections in section 7.3 .2 . 
Hydro pump pressure shall be maintained a minimum of $100 \pm 50$ psi less than Reactor system Pressure for the test duration.

7.4.4 Perform leak tests per sections 7.1 .2 through 7.1 .5 .

NOTE: The cold leg injection lines (to

RCS Loops $2 \& 3$ ) may be pressurized independently or simultaneously at the Test Director's discretion. Because of common leakage collection points, if the 2 injection lines are pressurized simultaneously any leakage coming from their respective check valves will be indistinguishable as to origin. Therefore maximum allowable leakage for this condition remains 1 GPM, even though leakage collection is from two independent check valves.

\subsubsection{Disconnect hydro pumps.}

7.5 Determine check valve back leakage of the cold leg injection line check valves QlEllv051C using Reactor Coolant Pressure.

7.5.1 Verify closed or close QIEIIV063(8885), Q1E2IV004A \& B (8801A \& B), Q1EIIV023A (8888B) and Q1E11V043A (8972A). Before closing V023A(8888B), verify Q1EIIV024A \& $B(8887 A \& B)$ open, then turn off RHR $B$ Train pump.

7.5.2 Install test rig (described in section $3.0)$ to test connection QV415F, QV074B or QV559B. Test connection valve will be selected in field by Test Director or his designated alternate.

7.5.3 Perform leak test per sections 7.1 .2 through 7.1 .5 .

7.6 Determine check valve back leakage of the cold leg injection line check valves Q1ElIV021C(8973C), Q1E2IV062C(8997C) and Q1E2IV066C(8995C).

7.6.1 Verify closed or close valves Q1ElIV063(8885), Q1E2IV004A \& B (8801A \& B), Q1EIIV023A(8888B) and QIEIIV043A(8972). Before closing QV023A (8888B), verify Q1EIIV024A \& B $(8887 A \& B)$ open, then turn off RFR B Train pump. 
7.F.2 Install test rigs (described in section $3.0)$ t:o test connection valves QV049C for QV021C, QV562B or QV416B for QV062C and QV4I8R for V066C. Test connection valve will be selected in Eield by Test Director or his designated alternate.

7.6.3 Connect hydro pump to vent and/or drain valves used as test connections in Section 7.5.2. Hydro pump pressure shall be maintained a minimum of $100 \pm$ 50 psi less than reactor system pressure for the test duration.

7.6.4 Perform leak tests per section 7.1 .2 through 7.1.5.

7.6.5 Disconnect hydro pumps. 
$1 \cdot 13$

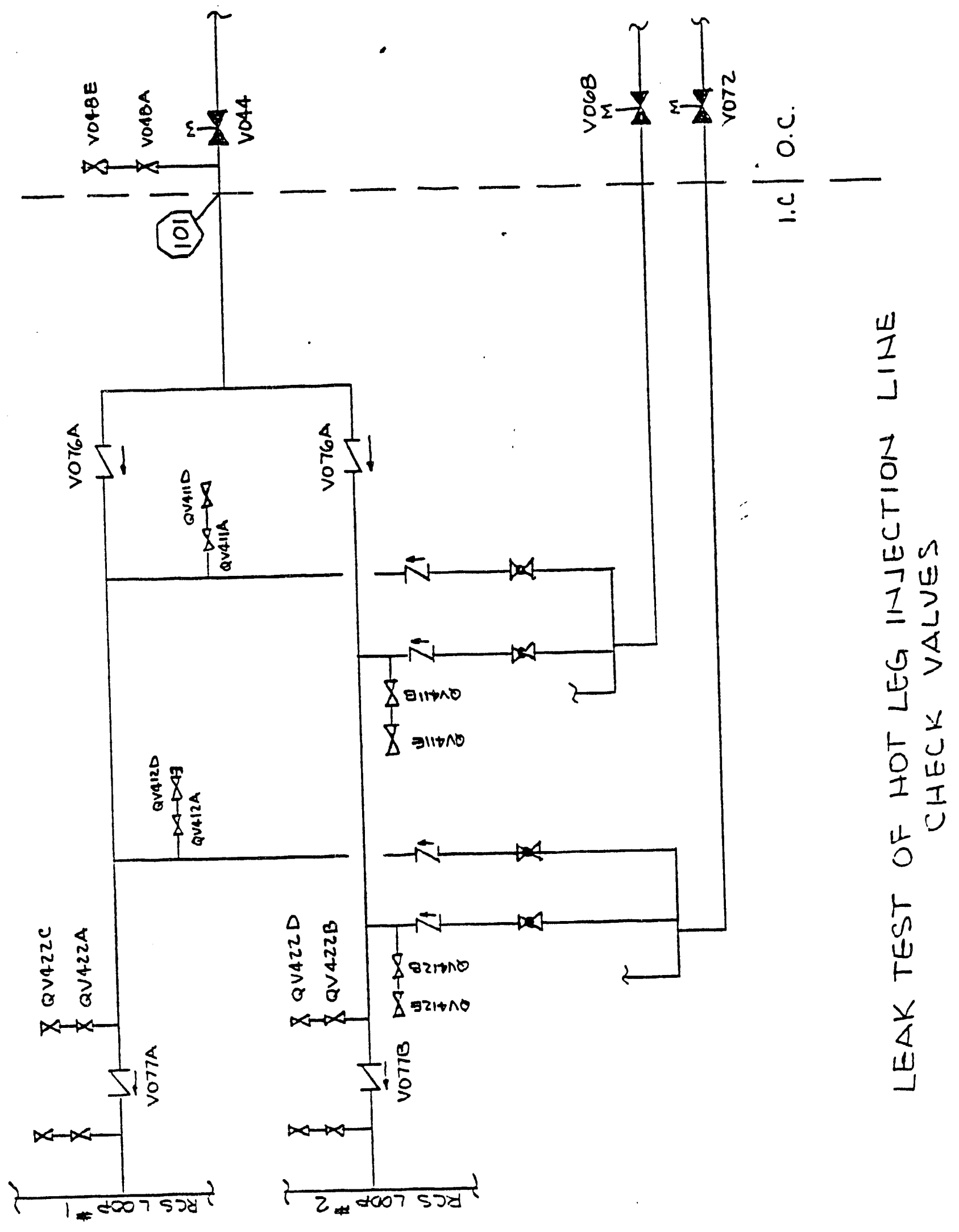

$8 s 1-d-5$ 
1 nכy

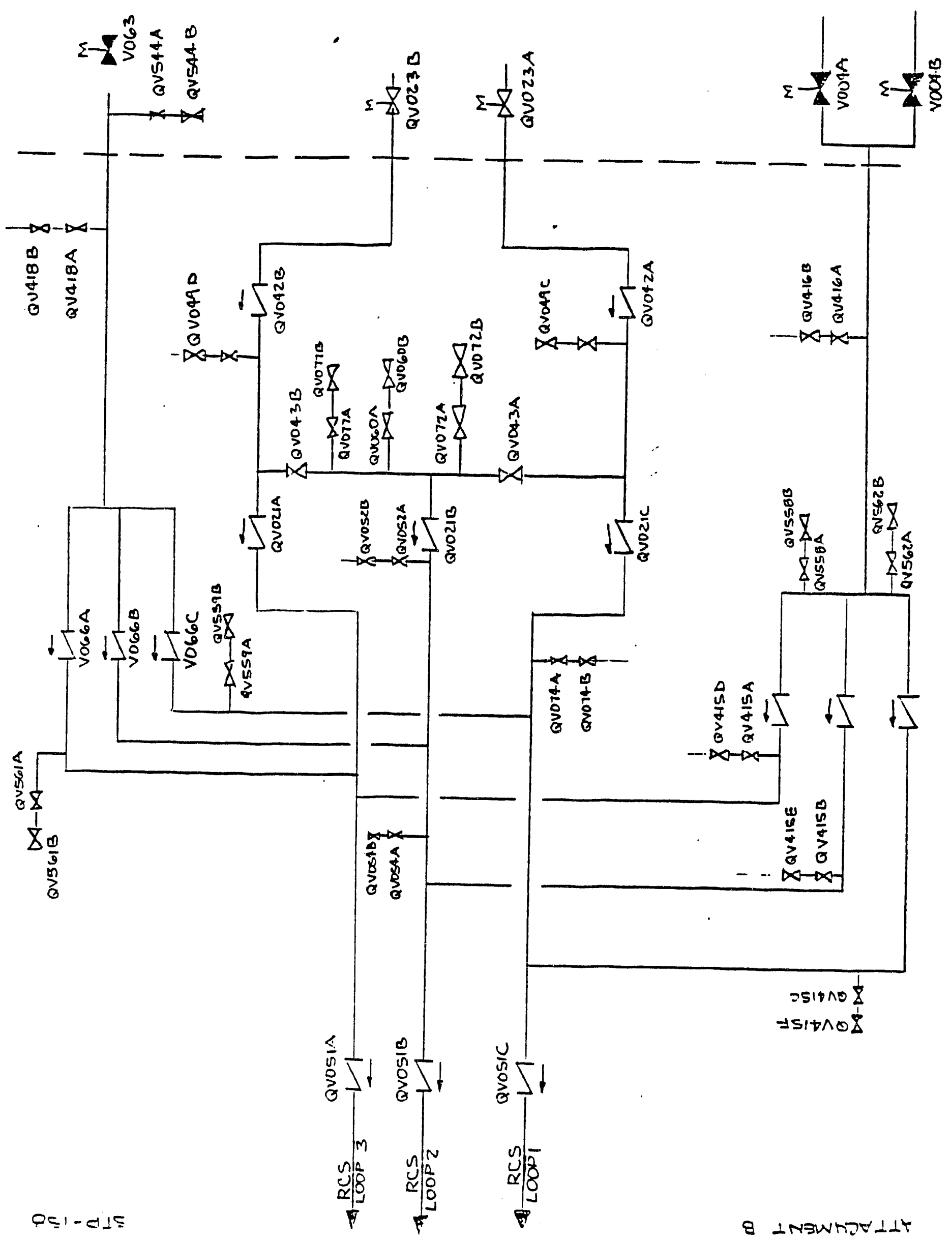



Utility D 
NOTE: The numbers on this Attachment refer to the questions in your letter.

1. The 1974 Edition, Summer 1975 Addenda of the ASME Boller and Pressure Vessel Code, Section XI is Implemented for in-service leak testing requirements for Unit 1 and 1977 Edition, Summer 1978 Addenda is used for Unit 2 .

2. See Table 1
a. See Table 2
b. No valve has missed a required in-service leak test.

3. The Survefllance Instruction (SI) is the basic operational procedure used for leak testing. This package includes the procedure (Testing Method and Instructions) and the data sheet (Record of Test Results). Attached are SI-166.10, 166.11, and 166.18 whIch makeup the category " $A$ " Testing Program. Also attached are the corresponding flow diagrams for these SI's: SI-166.10 47W 811-1

SI-166.11 47W 811-2 SI-166.18 47W 810-1

4. a. Thus far, personnel exposure to radiation has presented no problems in meeting leak testing requirements. However, as plant radiation levels Increase, personnel exposure may become a greater problem in the future.

b. The avallability of qualified personnel has presented no problems in meeting in-service leak testing requirements.

c.\&d. Yes, component accessibility has presented problems. Vent valve test connections, due to their high locations, present a safety hazard to test personnel. However, we can perform the leak test as destgned.

Also, the design of the leak test system is such that a leakage may be Indicated without the system being lined up to a specific check valve. This is caused by system leakage which is not constant. Since the system leak rate varies, it is not posstble to predict when a valve will exceed its maximum allowable leak rate. This is clearly shown by the leak rates on Table 2 .

e. Documentation requirements have not been found unnecessarily restrictive.

f. In-plant rotometers have been found to be unrellable and have caused delays. These delays, however, have not affected plant startup. 
g. Interpretation of ASME Section XI has presented some problems in determining exactly which valves require in-service testing.

5. Acceptance criteria for each valve may be found in its respective SI. This criterla is usually a leak rate of $<1 \mathrm{gpm}$. Th1s criterla may prove to be restrictive in the future. It is generally felt that criteria of $<10 \mathrm{gpm}$ would not be unreasonable.

6. At time of design, this plant was not under ASME Section III and XI requirements.

7. Attachment 1 is the applicable portion of Plant Technical Specifications which outlines in-service leak testing of Category "A" Valves. 


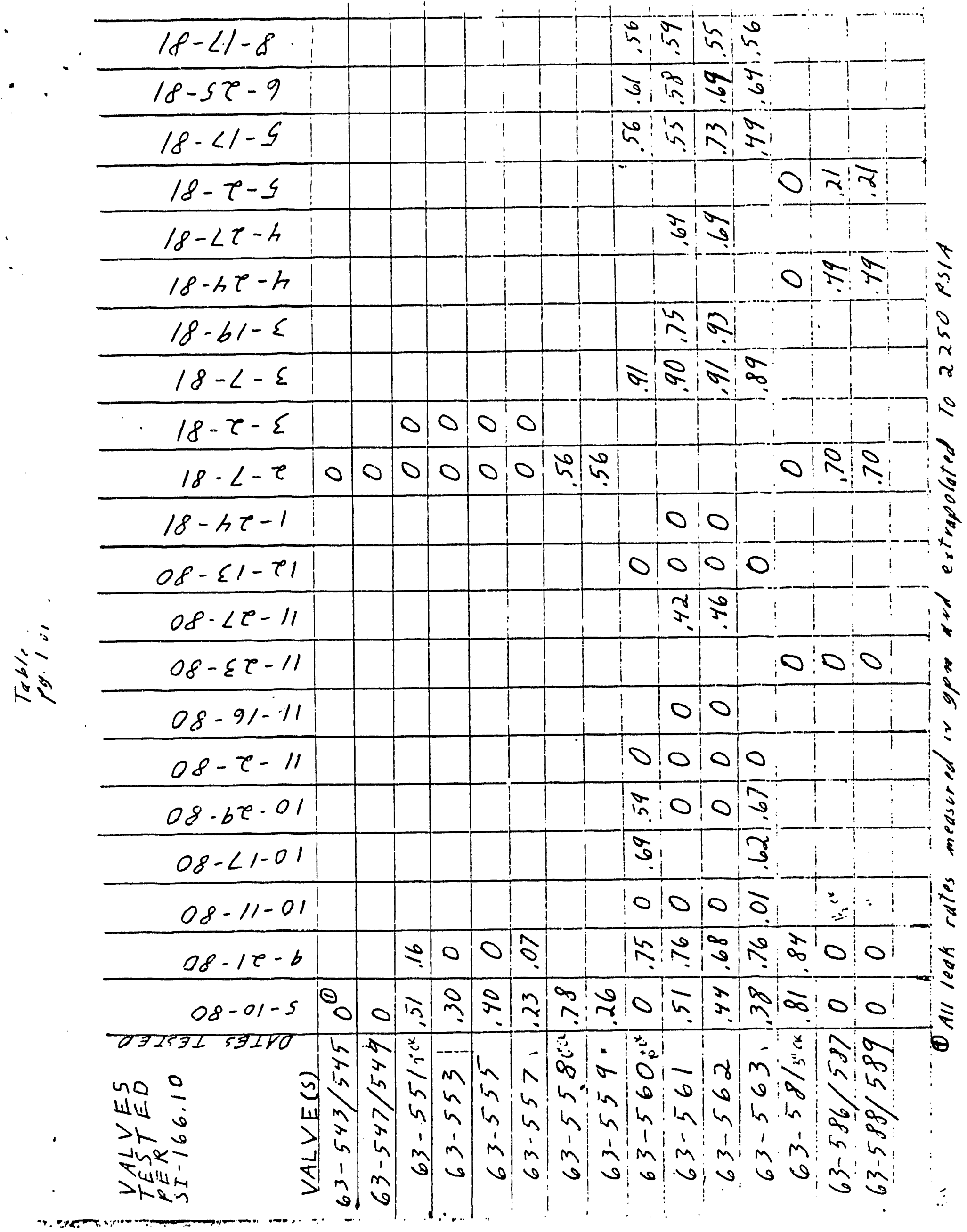




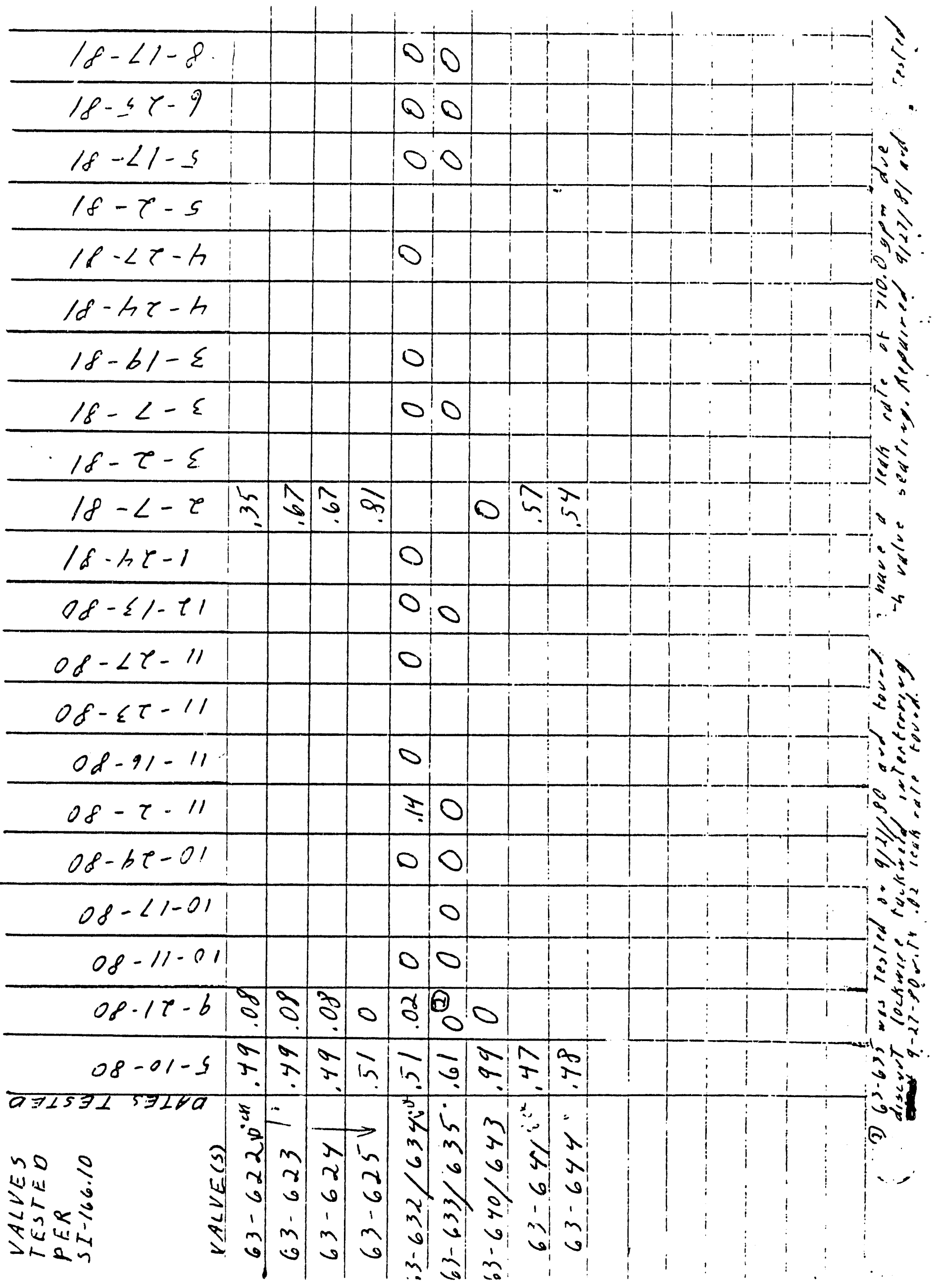




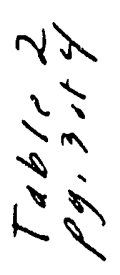

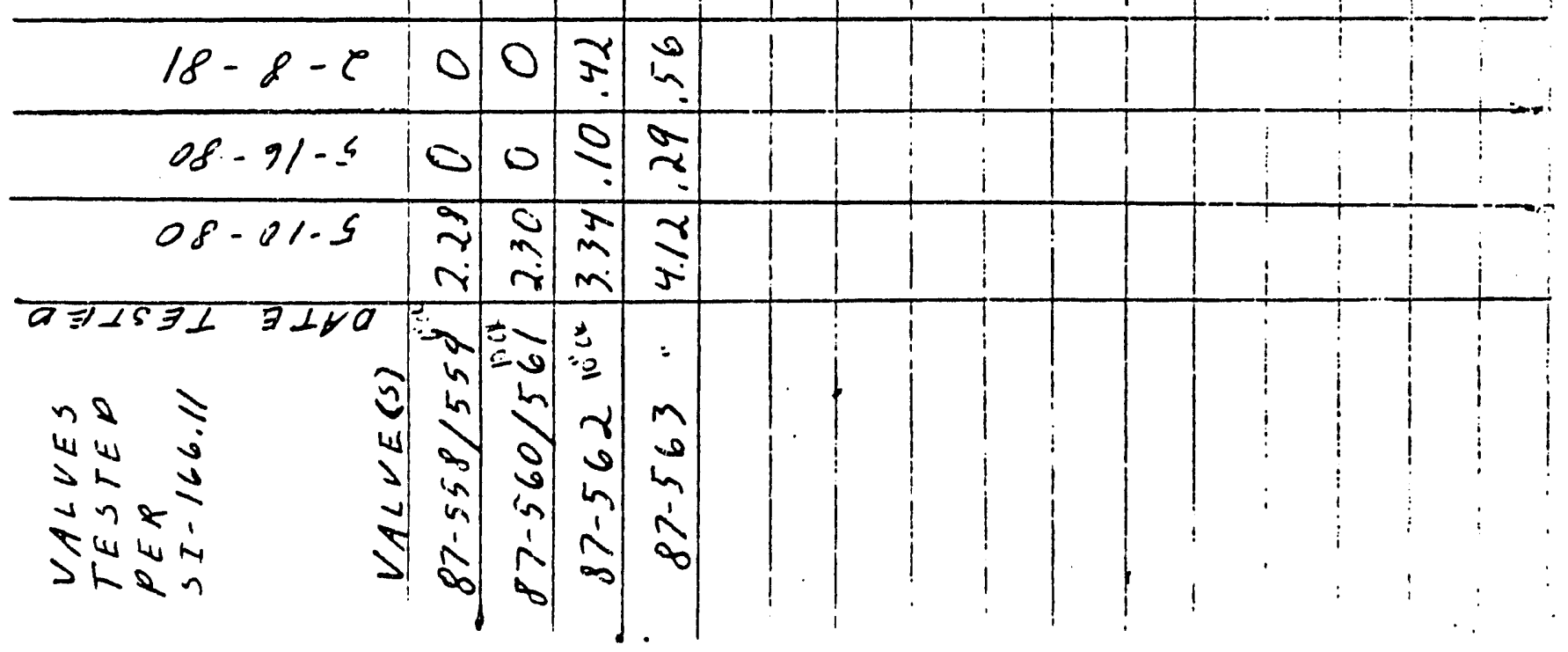




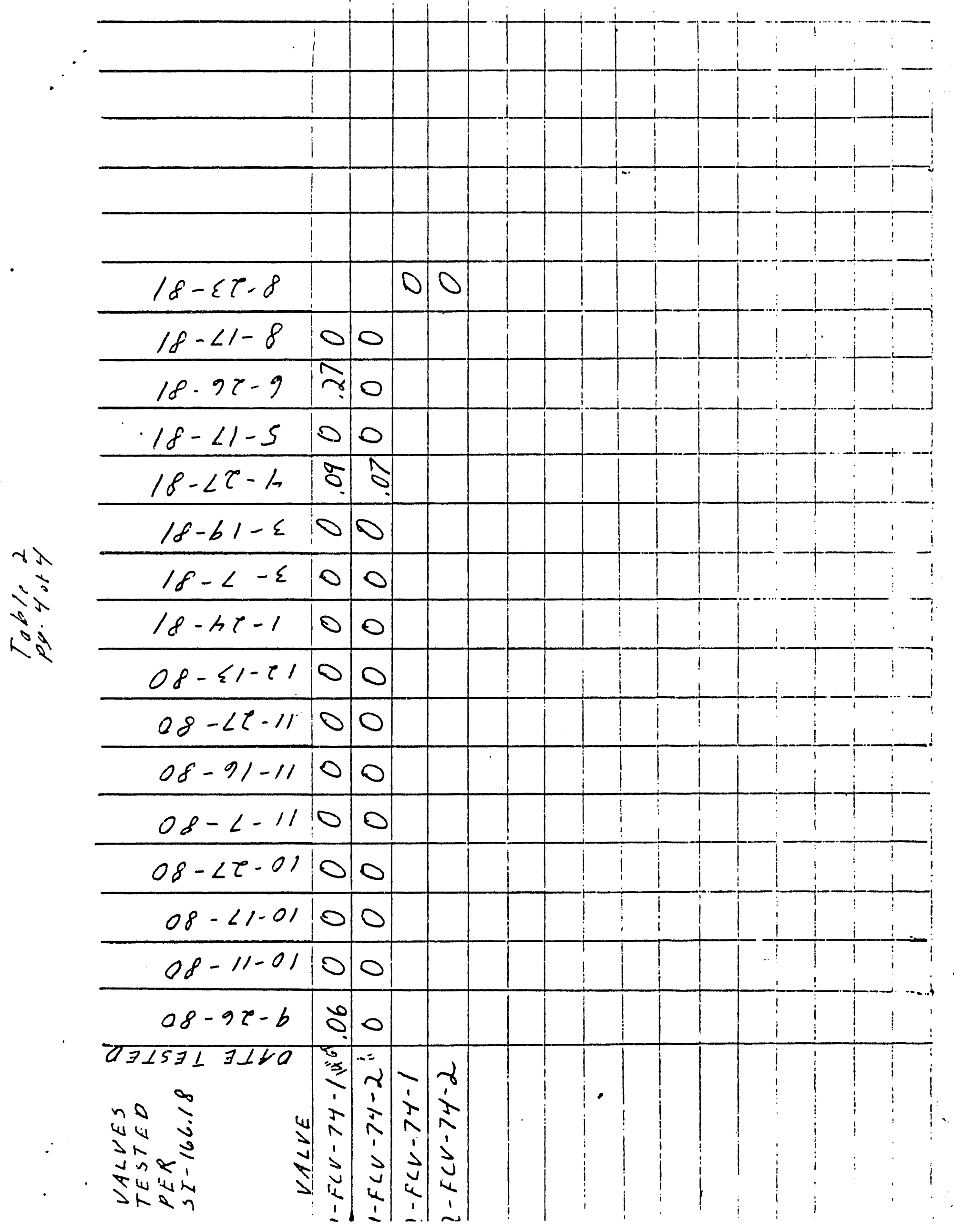




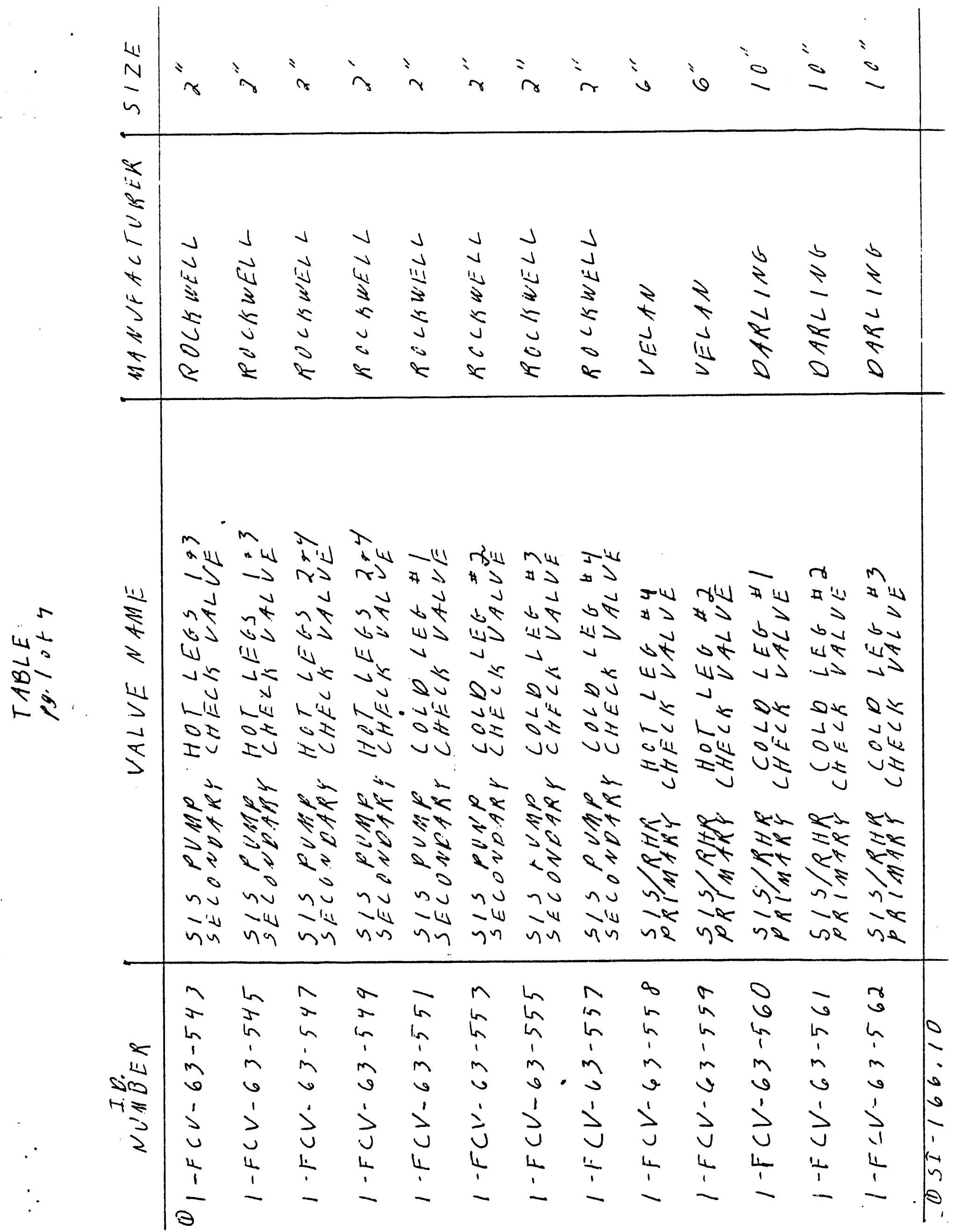




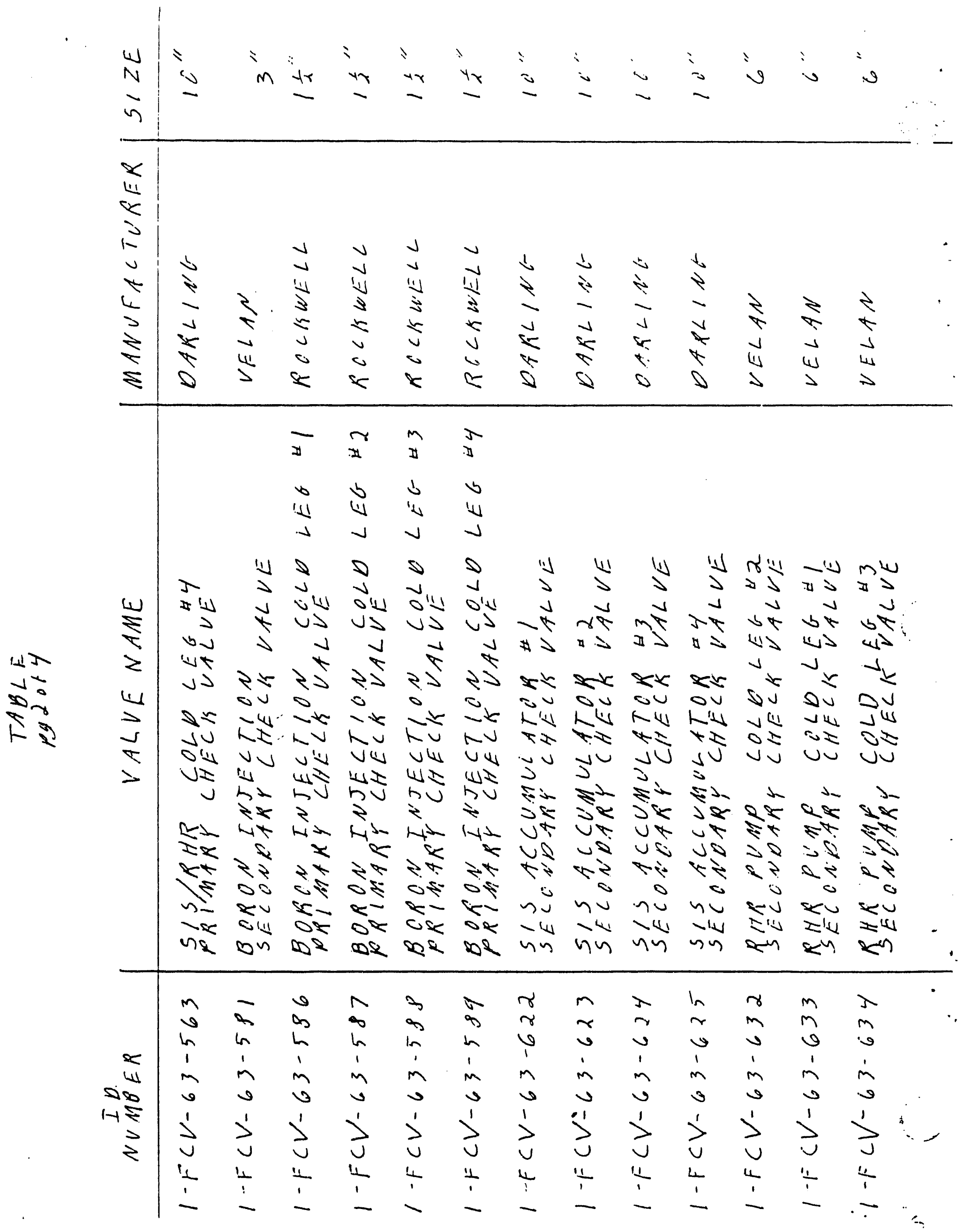




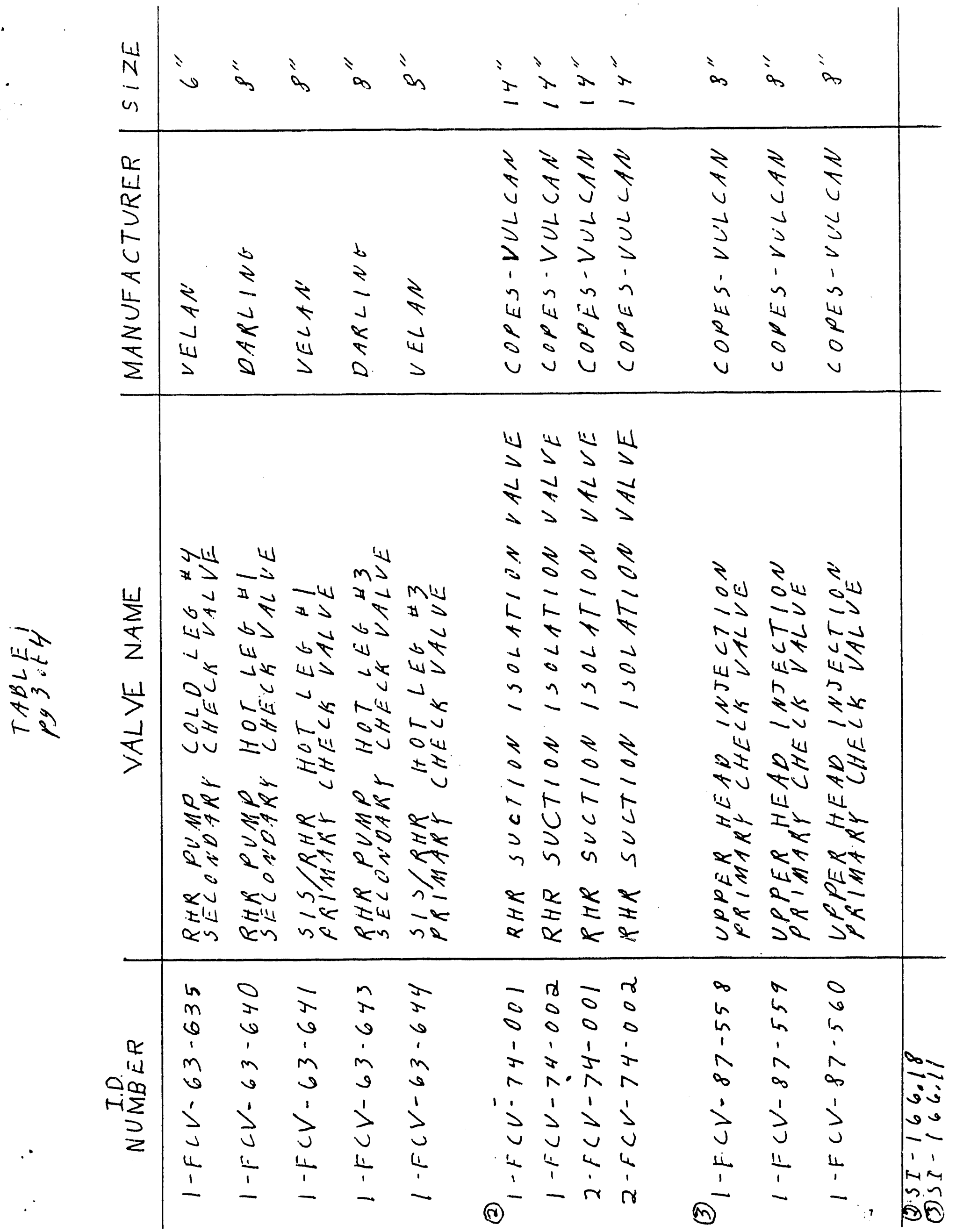


a. Monitoring the lower containment atmosphere particulate racioactivity menitor at least once per 12 hours.

b. Monitoring the containment pocket sump inventory and dischirge at least once per 12 hours.

c. Measurement of the CONTROLLED LEAKAGE to the reactor coolant pump sedls when the Reactor Coolant System pressure is $2235 \pm 20$ psig at least once per 31 days with the modulating vaive fully offen. The provisions of specification 4.0 .4 are not applicable for entry into Mode 4.

d. Performance of a Reactor Coolant System water inventory balance at leasi once per 72 hours.

e. Monitoring the reactor head flange leakoff system at least once per 24 hours.

4.4.6.2.2 Each Reactor Coolant System Pressure Isolation Valve specified in Table 3.4-1 shall be cemonstrated OPERABLE pursuant to specirication 40.5 . except trat in lieu of any leakage testing requirements required by Specification 4.0 .5 , each valve shall be demonstrated OPERABLE by verifying leakage to be within its limit:

a. At least once-per 18 months.

b. Prior to entering MOOE 4 whenever the plant has been in COLD SHUTDOWN for 72 hours or more and if leakage testing has not been performed in the previous 9 monens.

c. Prior to returning the valve to sarvice following maintenance, ropair cr replacement work on the valve.

d. Within 24 hours following valve actuation due to automatic or manual ac:ion or flow through the valve. 
TABLE $3.4-1$

\section{REACTOR COOLANT SYSTEM PFESSURE ISOLATIOAN VALVES}

VALVE NUMABER

$63-586$

$63-587$

$63-588$

$63-589$

$63-581$

$63-560$

$63-561$

$63-562$

$63-563$

$63-622$

$63-623$

$63-624$

$53-625$

$63-551$

$63-553$

63-557

$63-555$

$63-632$

$63-633$

$63-6.34$

$63-535$

63-641

$63-644$

63-558

$63-559$

$63-543$

63-545

$63-547$

$63-5119$

$63-640$

$63-543$

$87-5158$

$87-599$

$87-560$

$87-561$

$87-562$

$87-563$

FCV $-i c-1$

FCV $-7 \dot{4}-2$
FUNCTION

Beron Injection

Boron Injection

Boron Injection

Boron Injection

Boron Injection

Accumulator Discharge(1)

Accumulator Discharge (1)

Accumulator Discharge (

Accumulator Discharge

Accumulator Dischirge

Accumulator Discharge

Accumulater Discharge

Accumulator Discharge

Safety Injection (Cold Leg)

Safety Injection (Cold LeG)

Safety Injaction (Cold Leg)

Safety Injection (Coid Leg)

Resicual Heat Removal (Cold Leg) (I)

Residual Heat Removal (Coid Leg) (I)

Residual Heat Removal (Cold Leg) (I)

Residual Heat Removal (Cola Leg) (I)

Residual Heat Removal/Sarety

Injection (Hot Leg)

Residual Heat Removal/Saiety'

Injection (Hot Leg)

Safety Injection (Hot Leg)

Safety Injection (Hot L.ag)

Safety Injection (Hot Leg)

Safety injection (Hot Leg)

Safety Injection (Hot Leg)

Saiety Injection (Hot Lag)

Residual Heat Removal (Hot Lej)

Residual Heai Removai (Hot Leg)

Upper Head injection

Upper Head injection

Upper Head Injection

Upper Head Injection

Upper Head Injection

Upper Head Injection

Residual Heat himoval (I;i(2)

Residual Heat Removal $(i,(2)$

(1) The valves must be tested prior to entering l:ODE 2.

R5

(2)

The leakage limit for these valves is 3 GPM.

This value will

be finalized within 30 days of issuance of this amendment.

$3 / 4 \quad 4-153$

$12 / 22 / 30$

REVISION 8

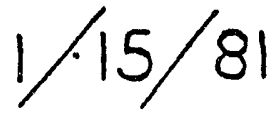


$S I-166.10$

rage 1 of 13

Rev. 5

\section{$1.0 \quad$ SCOPE}

1.1 Test Description

Measure the leak rate of the accunulator/injection primiry and second.: $y$ check valves. This is performed by pressurizing the down stream side of the check valve and measuring the leakage on the upstream side.

1.2 Objective

Verify that the leakage through eash check valve when tes utd and extra-polated to full RCS pressure is less than or cqual to 1 gprn.

\subsection{Requirements}

1.3.1 The Category A ASME Section XI valves are required to ve leak tested per SR 4.0.5.

1.3.2 Fulfill SR 4.4.6.2.2.a - each valve shall be demonstraced OPERABLE by verifying leakage to be within its ilnits at least once per 18 months.

1.3.3 Fulfill SR 4.4.6.2.2.b - each valve siall be demociotrated OPERABLE by verifying leakage to be within its linits prior to entering the required mode ${ }^{1}$ whenever the plant has been in Cold Shutdown for 72 hours or more and if leakage testing has not been performed in the previous 9 months.

$1.3: 4$

Fulfill SR 4.4.6.2.2.c - each valve shall be demonitrated OPERABLE by verifying leakage to be within its limits prior to returning the valve to service following mairtconance, repair or replacement work on the valve.

1.3.5 Fulfill SR 4.4.6.2.2.d - each valve shall be demoustraled OPERABLE by verifying leakage to be within its l lirits within - 24 hours following valve actuation due to autoinsti= or. manual aption or flow through the valve.

\section{* ${ }^{1}$ NOTE: Required Modes}

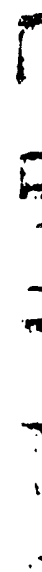

Unit 1

Parts $A$ and $B$ shall be in required frequency and performed prior to entry into Mode 4 and Part $C$ shall be in required frenuercy and performed prior to entry inco Mode 2.

$\underline{\text { Unit } 2}$

Parts $A$ and $C$ shall be in required frequency and perforned prior to entry into Mode 2. Part B does not apply to Unit 2.

×. NOTE: $*$

SI-166.10 and 166.11 satisfy category "A" for the SIS/iaccumulatur check valves. The category " $C$ " portion is performed in SI-166.12. 
$S I-166.10$

Pige 2 of 13

liev. 5

\subsection{REFERENCE}

e

ह.'.

:

\subsection{PREREQUISITES}

$\therefore \quad 3.1$ Obtain permission from shift engineer to perform test.

$7 \because$

!

3.2 Open or verify open $63-666,63-601$ and $62-953$ to create is leikage path from test system to CVCS holdul tank.

* 3.3

When the instruction calls for installation of test flanges in place of blind flanges, the following items apply:

3.3.1 Need/Actions - The blind flanges must be renoved and replaced wita test flanges to allow the required leak tests to be jertiorned.

\subsubsection{Effects of Test Flange Installation - Nonc}

3.3.3 Limitations - The test flanges must be removed and lise blind flanges re-installed prior to Mode 2 .

NOTE: No TACF is required for removal or blind tilanges and replacement with test flanges.

\subsection{PRECAUTIONS}

4.1 Ensure that the pressure-temperature of the RCS is maintained within tne acceptable limits per STS 4.9.1.

4.2 Ensure that the required ECCS is maintained while purtorming this instriction per STS $3 / 4.5 .3$.

4.3 Operations should not operate any valves in system 63 duriug this test except at direction of test engineer or in an accident situation.

5.0 INSTRUCTIONS FOR PART A (This section applies to Units 1 and 2)

NOTE: Part A shall be performed prior to entry into Mode 4 if requircu for Unit 1 and prior to entry into Mode 2 for Unit 2.

NOTE: Ensure RCS pressure is greater than accumulatur pressurc before perforaing Part A instructions if an accumulator fill valve is to be opered.

5.1 Leak test of check valves 63-5.51, 63-553, 63-555, and 63.557 (SIS CL Secondary Check Valves) using RILR pump.

5.1.1 Verify both RIR pumps are in service. If both Rllk pumips are not in service, open FCV-63-111 and FCV-63-112 and verity

one RIR pump is in service and either FCV-03-93 $0:-94$ is open. 
$S I-166.10$

Page 3 of 13

Rev. 5

5.1.2 Install a test flange in place of blind flunge on vent valve 63-654. Attach hose as necessary to be able to collect leakage from vent valves into a calibrated vessel. Verify on daca shee: when flange is installed. Obtain second person verification. NOTE: No TACF is required.

5.1.3 Close FCV-63-22.

5.1.4 Crack open vent valve 63-654 and allow pressure to bleed off system.

5.1.5 Fully open vent valve 63-654 and allow flow to stabilize fic several minutes.

5.1.6 Record RCS pressure on data sheet.

5.1.7 Collect any leakage into a calibrated vessel over a period of time. Calculate the leak rate by dividing the volume collected by the period of time.

5.1.8 Complete a leak rate for valves $63-551,63-553,53-555$ and 63-557 at an RCS pressure of 2250 psia ty multiplying the flow rate from 5.1 .6 above by $\sqrt{\frac{2250}{14.7+\text { rcs pressure }}}$ and record

this leak rate on data sheet.

NOTE: If the calculated leak rate obtained above is $>:$ GPM retest valves individually by performing step 5.9 .

5.1.9 Perform the following valve lineup:

5.1.9.1 Close vent valve 63-654

5.1.9.2 Open FCV $-63-22$ if required.

5.1.10 Close or verify closed FCV-63-111 and FCV-63-112.

-5.1.11- If valves passed leak rate of < 1 GPM romove test fiange and reinstall blind flange on vent valve 63-654. Verify blind flange installed on data sheet. Obtain second person verification on data sheet.

5.2 Leak test of check valves 63-543, 63-545 (SIS Pump Hot Leg 1 \& 3 Seconda:; Check valves) and 63-640,63-643 (RHRI HL 1 \& 3 secondary check valves).

5.2.1 Install test flanges in place of blind flanges on vent valves 63-657 and 63-639. Attach hose as necessary to be able to collect leakage from vent valves into a calibratac vessel.

$\stackrel{\hbar}{t}$ Verify flanges installed on data sheet. Obtain second person verification.

NOTE: No TACF is required.

5.2.2 Perform the following valve lineup: REPEATS For OTHER VALVES

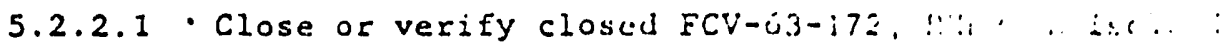
vilve. 
Utility E 


\section{INSERVICE TESTING OF. VALVES IN \\ NUCLEAR PONER PLANTS \\ SURVEY SHEET}

NRC TASK \#

$6367-9$

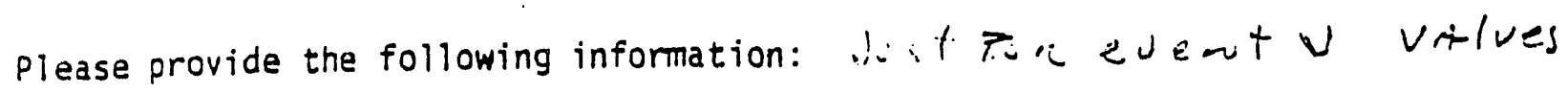

1. What version, year and addenda, of the ASME Boiler and Pressure Vessel Code, Section XI is implemented for "in service testing requirements" for your facility? 19747 hrou summen 754 strubrad tech spec reaviesments.

2. List all "Category A" primary pressure isoiation vaives in your facility for which the applicable edition and addenda of the ASME Boiler and Pressure Vessel Code, Section XI; Technical Specifications; or NRC orders, require periodic leak testing. Provide valve name, manufacturer, identification number, age, type, and size. Cremuc, $10^{\circ} 414, "$

$$
\text { duig \#H-3036s }
$$

a. Of the valves listed above, provide a history of the in-service leak testing they have received. Provide test medium, test pressure, and leak rates observed. List those valves found to be deficient during testing. Include the number of deficiencies observed for each valve over its service life to date. Describe each deficiency, and the corrective action taken. see Attrele 6

b. Of the valves listed in 2., above, list those which at some time during their in-service life to date have missed a required inservice leak test. For each omission, describe the circumstances which caused the leak test to be omitted. see Atachedpacedines

3. Provide a list and description of the various testing methods utilized to comply with ASME Section XI, as it applies to leak testing of "Category A" vaives at your facility. Include sketches of equipment used, together with test piping diagrams, and instrumentation types and locations. Also, include copies of operating procedures used for leak testing, together with examples of logs, records, or other documentation utilized to record the testing data for each valve type. see at Hachod 
4. What problems have been encountered in your facility with applicable in-service leak testing requirements and procedures?

a. To what extent has personnel exposure to radiation presented problems in meeting in-service leak testing requirements? No wasca problems.

b. Has the availability of personnel qualified to perform in-service leak testing, presented problems or caused in-service leak testing to be delayed? No,

c. Has component accessibility presented problems in performing inservice leak testing? yes

d. Has the original design of the facility, in regard to the availability and location of test taps or orifices, been adequate to allow performance of in-service leak testing? wo

e. Have documentation requirements been restrictive to an extent you consider unnecessary? Explain. No

f. Has in-service leak tiesting been hindered by the availability of test equipment or procedures? No

g. Has interpretation of ASME Section XI presented problems in establishing your in-service leak testing program? some with vorjue woudtwig in tech spec toud see. $x /$

List and describe any additional problems encountered.

5. List -- as a function of valve type, service, size, age, and manufacturer-the allowable leak rate you consider practical from the standpoint of measurement and valve repair.

6. Provide examples of design reports or comparable documentation which delineates the manner in which ASME Sections III and XI code requiraments for valves were met at the time of the original installation. 
7. Provide examples of applicable portions of Plant Operating Manuais, Inservice Inspection Manuals, Technical Specifications, or comparable documentation which outlines in-service leak testing of "Category A" valves in your :acility. 


\section{SURVEIILANCE PROCEDURE}

SP-405

Utility $E$

CORE FLOODING SYSTEM CHECK VALVE OPERATION

DEMONSTRATION AND LEAK TESTING 
1.1

Core flood system (CIS) check valve operation and leak

testing shall be demonstrated durlag the modes and at

the frequencles indicated below.

1.2 TECENICAI SPECIFICATION REFERENCES

\begin{tabular}{|c|c|c|c|c|c|}
\hline $\begin{array}{c}\text { Tech. Sper. } \\
\text { Wadver }\end{array}$ & $\begin{array}{l}\text { Surv. Perf. } \\
\text { During Modes }\end{array}$ & $\begin{array}{l}\quad \text { LCO/FPC } \\
\text { RequIrement } \\
\text { Dur1ng Modes } \\
\end{array}$ & $\begin{array}{l}\text { Surv. } \\
\text { Fred. }\end{array}$ & $\begin{array}{l}\text { Freq. } \\
\text { Nores } \\
\end{array}$ & $\begin{array}{l}\text { Mode } \\
\text { Notes } \\
\end{array}$ \\
\hline $\begin{array}{l}3.5 .1 \\
4.4 \cdot 6.2 .2\end{array}$ & 3 or 4 & $\begin{array}{l}1,2,3,4 \\
1,2,3,4\end{array}$ & $\begin{array}{l}\mathbf{R} \\
\mathbf{R}\end{array}$ & $\begin{array}{l}30 \\
27,30 \\
41\end{array}$ & $\begin{array}{l}70 \\
70\end{array}$ \\
\hline
\end{tabular}

SURVEIILANCE FREQUENCY:

R - Refueling ( 18 Months)

MODE NOTES :

70 - W1th reactor coolant system (RCS) pressure $>750$ psig. $700 \pm 20$ ps:

FREQUENCT NOTES:

27 - Prior to criticality.

30 - Prior to shutdown for refueling.

41 - Whenever the plant has been in cold shutdown for 72 hrs. or more and leakage test has not been performed in the previous 9 months.

\section{0} ACCEPTANCE CRITERIA

2.1 PART "A", CEECK VALVE OPERATION

2.1.1 A GF tank (CFT) level decrease with corresponding pressurizer level lncrease does occirs when RCS pres- 


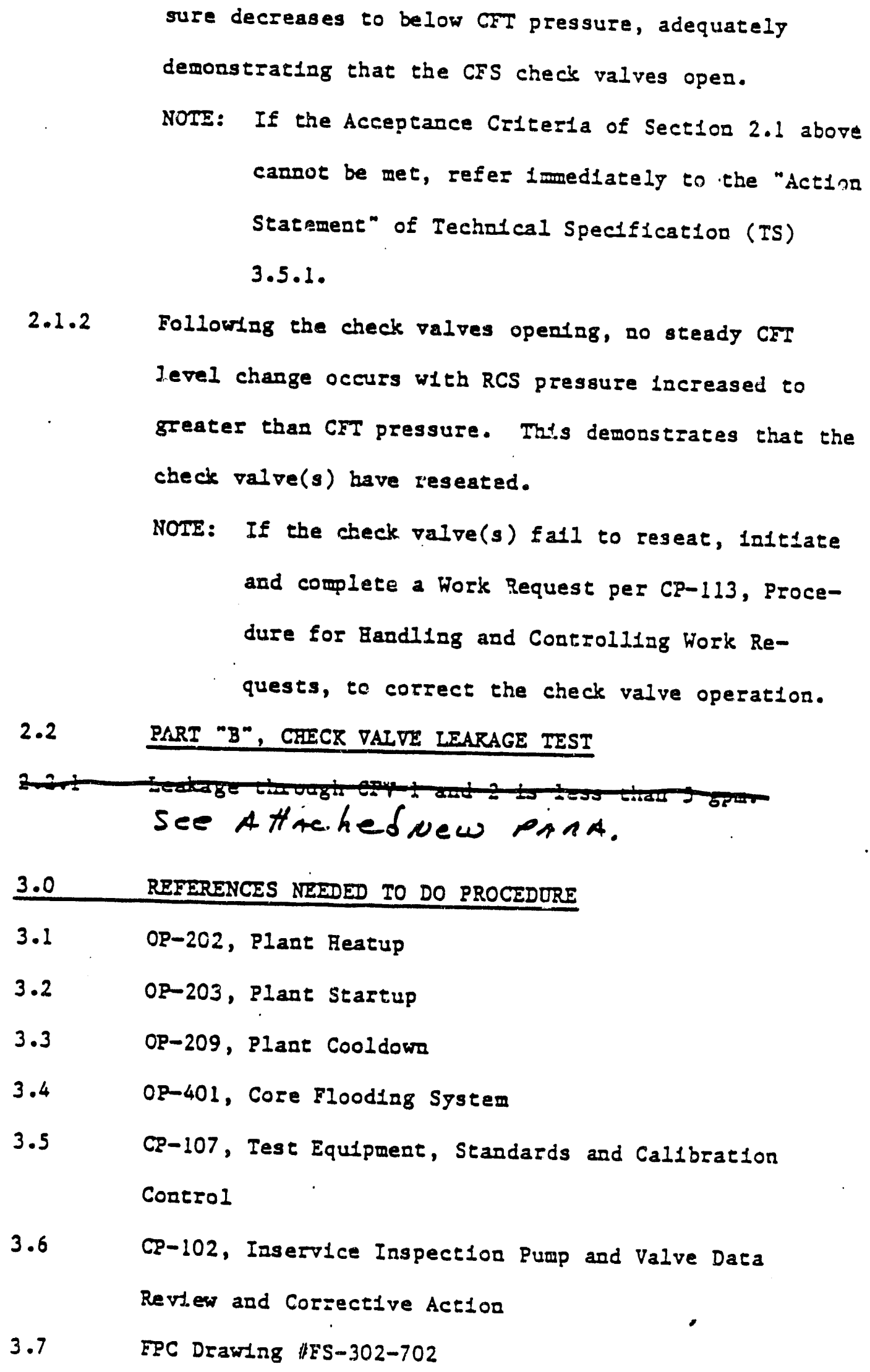




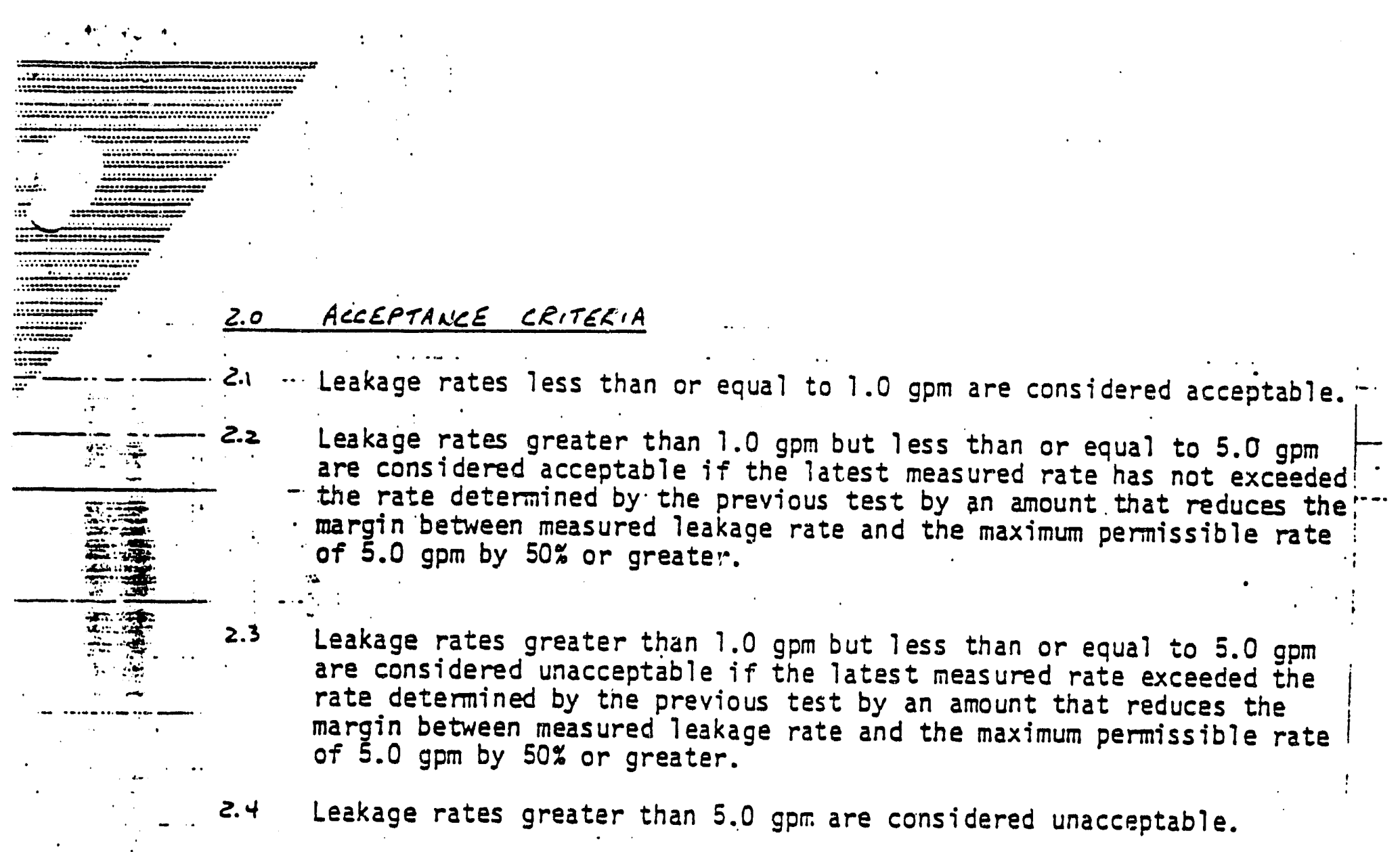


Utility $F$ 
1. Utility $F$ Units 1 and 2 are tested to ASME Boiler and Pressurizer Vessel Code, Section XI 1974 through summer of 1975 Addenda.

2. Attached is a table which is a list of all "Category A" primary pressure isolation valves for North Anna Unit 2. The list includes the valve mark number, function description, manufacturer, type, size, age and testing history. All of these valves are required to be tested pursuant to the Technical Specifications.

a. For all valves listed in the table, the test medium used was water. The test pressure used was dependent on plant and system conditions at the time of the test. The high side and low side test pressures are listed for each individual valve test. No valves tested to date have been found deficient.

b. None of the valves listed in the table have missed a required inservice leakage test.

3. Attached is a copy of 2-PT-61.4, RCS Pressure Isolation Valves Leakage Test. This periodic test delineates the specific test procedure for each valve or pair of valves. Reference drawings 12050-FM-94A, $96 \mathrm{~A}, \mathrm{~B}$ are attached, which provide valve operating numbers for the residual heat removal system and the safety injection system, sheet 1 and 2 , respectively.

4. a. All of the valves that are required to be tested are either inside the containment building or in a pipe penetration area directly adjacent to the containment. All of the testing requires test personnel to dress out in full protective clothing and many cases a full face respirator. The radiation exposure levels are not extremely high, although personnel contamination has been a problem. In most cases, the leak rate is determined by maintaining a pressure differential across a valve by bleeding water from the low pressure side. The water is reactor coolant water and can be fairly hot, radiologically.

b. The test procedure is written such that any experienced operator should be able to conduct the in-service leak surveillance. The availability problem occurs due to the total number of operators required to perform leak testing in addition to the normal required shift complement. Shift personnel are required to work overtime during the in-service leak testing.

The valve testing can only be performed with the reactor coolant system in a narrow temperature and pressure window. At these conditions, the heat up must be terminated and the primary maintained at these conditions for the duration of the leak testing. This forces the testing into a critical, path position for outage planning. The outage down time is increased by the time 
b. (Continued)

required to conduct all the leak testing. Prior experience at Utility $F$ indicates that the in-service leak testing accounts for 1-2 days of lost electrical generation per outage.

c. Component accessibility has presented problems that increase the time required to perform in-service leak testing. A majority of the valves that are tested are located near the containment wall adjacent to many other pipe penetrations. The drain and vent valves are difficuit to access due to the congestion in the pipe penetration vicinity. In order to install the test apparatus to a drain valve, close physical contact with adjacent piping increases the possiblity of personnel contamination.

d. Westinghouse nuclear steam supply systems are designed to have fail safe redundancy by providing two or more parallel flow paths. Each flow path has its own valve with no other isolation valves provided for maintenance or testing. This type of configuration requires two or more valves to be tested concurrently while contributing the entire leakage to each valve. This testing technique has been adequate to date.

e. Documentation requirement, or more precisely, administrative requirements, place an unnecessary burden on the test personnel. The testing procedure must be written to provide an unambiguous sequence of steps, and in so doing, disallow the flexibility that is required by the plant status. For example, depending on the availability of the accumulators to serve as pressure sources, the procedures may have to be deviated to allow a different pressure source. The additional deviations and subsequent Station Nuclear Safety and Operating Committee approval increase the amount of documentation and personnel time.

f. The test equipment required is relatively simple and consists of a pressure gauge, valve and a length of high pressure flexible hose. The availability of test equipment or procedures has not hindered in-service leak testing appreciably.

g. Interpretation of ASME Section XI has not presented problems in leak testing.

5. The leakage specified in the Utility $F$ Unit 2 Technical Specifications is practical from the standpoint of measurement and valve repair. The allowable leakage is 1 GPM except for any RHR system isolation valve. The RHR valves have an allowable leakage of $5 \mathrm{GPM}$.

The problem with testing of all the valves is the requirements of ASME XI Section XI (IWV-3420) with regard to the direction of pressurization and the use of pressure differentials lower than function pressure differentials. The code does not allow testing a valve in either direction unless the function differential pressure is less than 15 psi. No RCS boundary isolation valves fall into this category. Several of the motor operated gate valves would be easier to test in the direction opposite to the function direction. 
ASME Section XI specifies the relationship to be used when adjusting a test leakage to the leakage that would be expected at the function differential pressure. The leakage is calculated to be proportional to the square root of the pressure differential. This relationship assumes that the leak path cross-sectional area remains constant at any differential pressure. This assumption is extremely conservative when it is applied to check valves, since increasing the differential pressure tends to reduce the leakage. The test differential pressure is generaliy limited by the low side saturation pressure and the temperature vs. pressure condition of the reactor coolant system. To keep the water temperature below $200^{\circ} \mathrm{F}$, the RCS pressure must be maintained below 450 psi. All of the valves that are being tested are designed for a differential pressure of about 2200 psi. At the lower differential pressure used for testing, the check valves may not seat properiy.

6. The original testing documentation is not available at North Anna.

7. The in-service leak testing of the subject "Category A" valves is delineated in 2-PT-61.4, RCS Pressure Isolation Valves Leakage Test. 


\begin{tabular}{|c|c|c|c|c|c|c|c|}
\hline 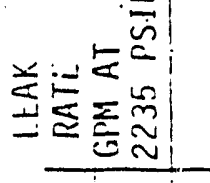 & $\begin{array}{l}0 \\
0 \\
0\end{array}$ & 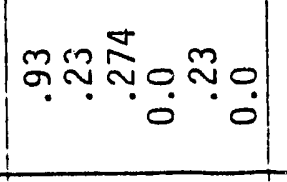 & $\therefore 0$ & $\begin{array}{l}00 \\
00 \\
00\end{array}$ & $\because 00$ & $\dot{0} 0$ & $\begin{array}{l}00 \\
00 \\
0\end{array}$ \\
\hline 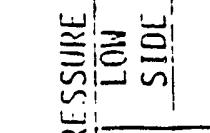 & i̊ & m요 & .8 & 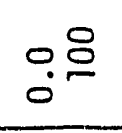 & $8 \stackrel{8}{\circ}$ & $\infty$. & $\infty$ \\
\hline 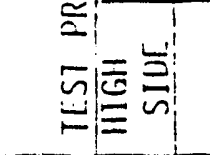 & 点占 & 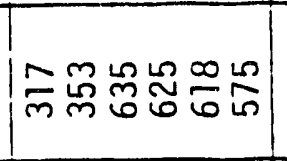 & 总怘 & 哭点 & 勇 & 总总 & 总品 \\
\hline 点㟃 & 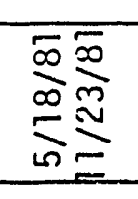 & 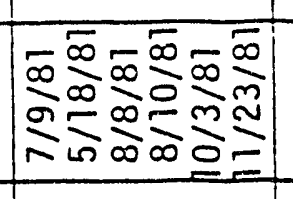 & 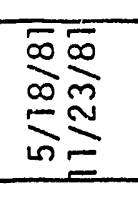 & 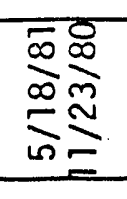 & 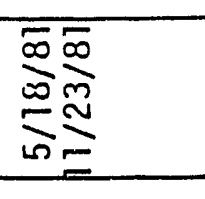 & 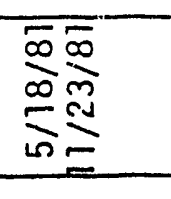 & 亦京 \\
\hline 岕产司国 & $\stackrel{2}{\Omega}$ & $\stackrel{n}{2}$ & $\stackrel{\Omega}{\Omega}$ & $\stackrel{5}{9}$ & $\stackrel{n}{g}$ & $\frac{n}{2}$ &.$\stackrel{2}{\Omega}$ \\
\hline 岂嵌 & $\bar{m}$ & $\bar{m}$ & $\bar{m}$ & $\bar{m}$ & $\bar{m}$ & $\bar{m}$ & $\bar{m}$ \\
\hline 崖嵌 & 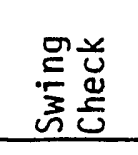 & 苞苞 & 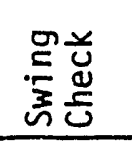 & $\begin{array}{l}\text { 曷总 } \\
\text { 总 } \\
\end{array}$ & 薦 & $\underset{0}{\stackrel{ \pm}{0}}$ & 芯 \\
\hline 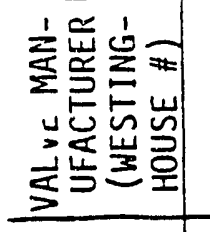 & 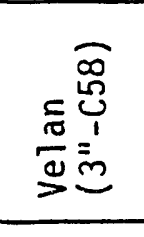 & 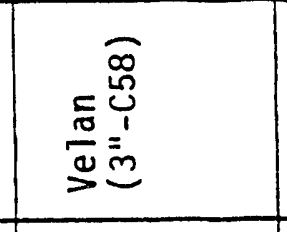 & 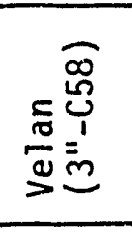 & 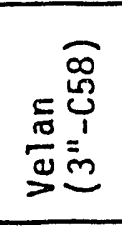 & 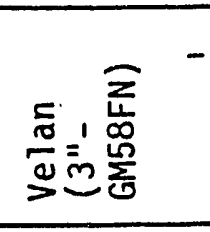 & 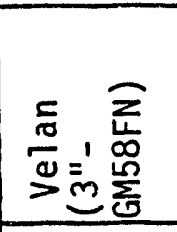 & 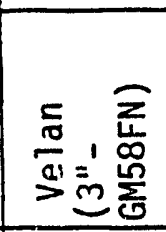 \\
\hline 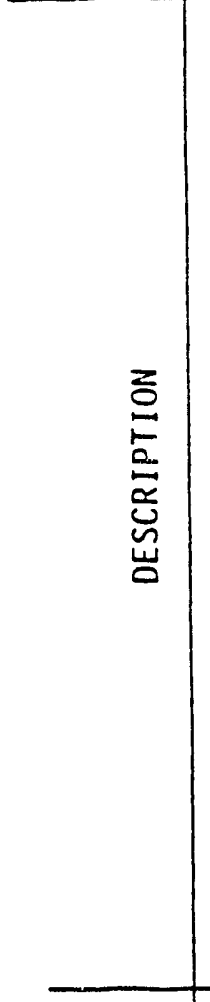 & 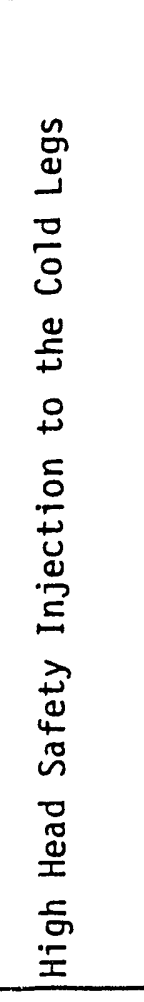 & 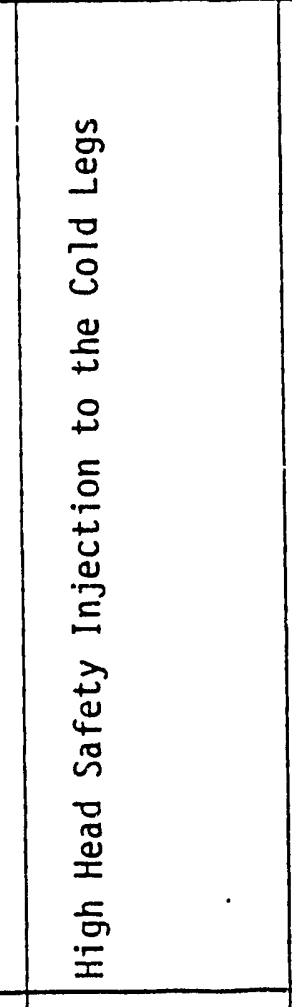 & 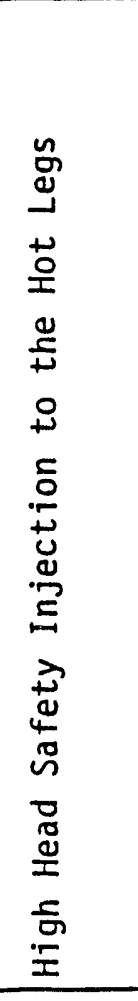 & 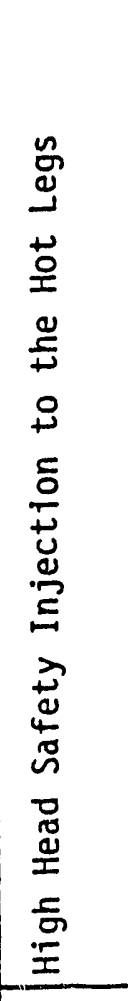 & 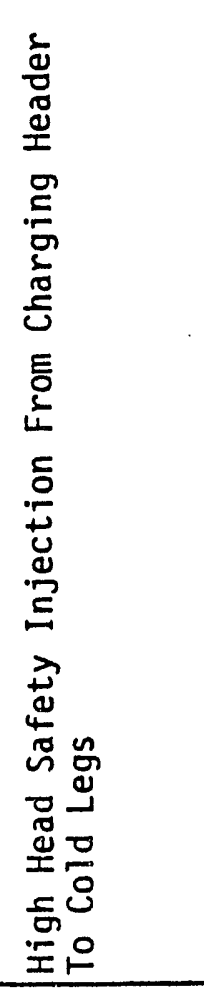 & 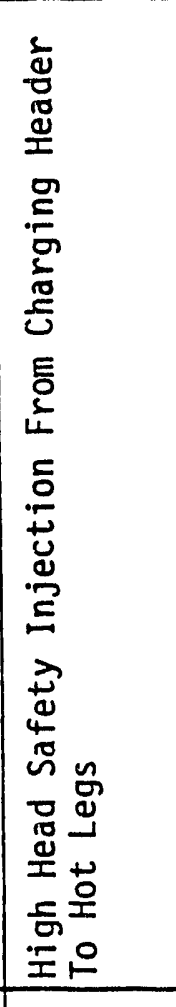 & 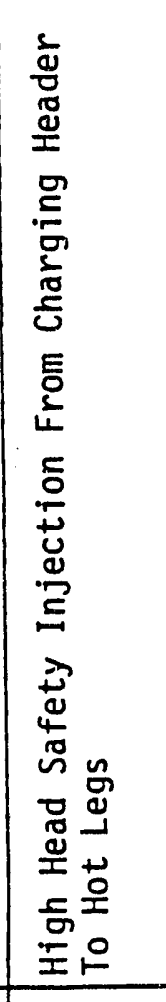 \\
\hline 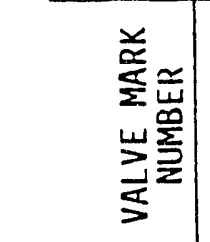 & $\begin{array}{l}\infty \\
\dot{1} \\
\dot{\sim}\end{array}$ & $\begin{array}{l}m \\
\dot{a} \\
\dot{\sim} \\
\sim\end{array}$ & $\begin{array}{l}\frac{0}{1} \\
\stackrel{\Delta}{\sim}\end{array}$ & 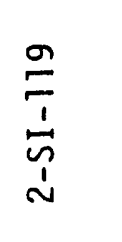 & $\begin{array}{l}\stackrel{\infty}{0} \\
\stackrel{0}{1} \\
\stackrel{0}{2}\end{array}$ & 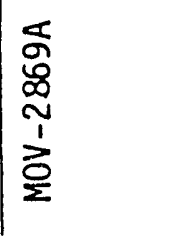 & 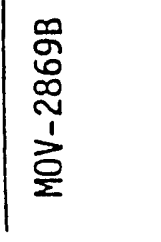 \\
\hline
\end{tabular}




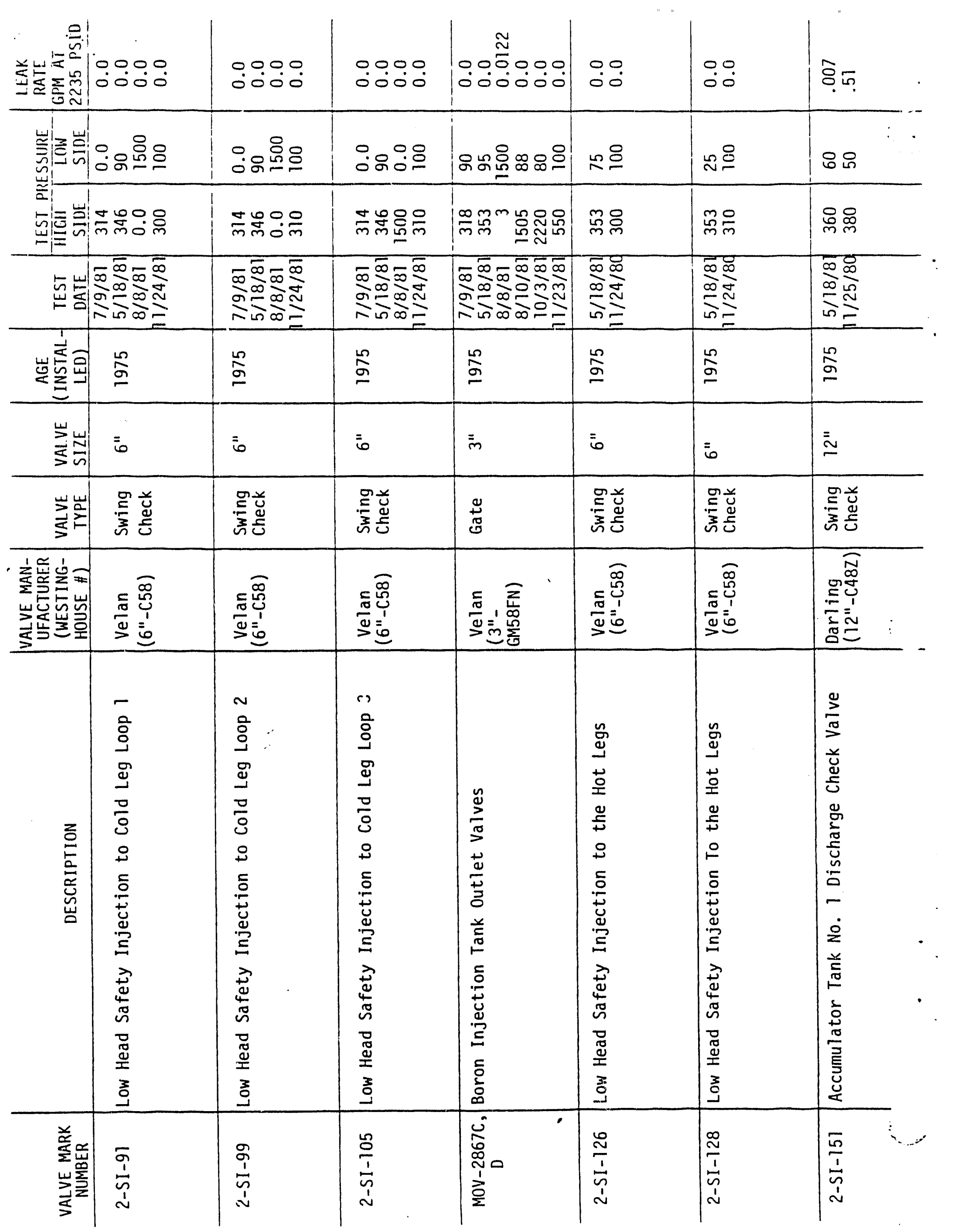




\begin{tabular}{|c|c|c|c|c|c|c|c|}
\hline 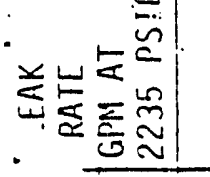 & 芯 & 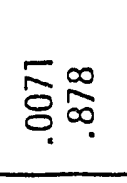 & ma:0.0 & :0.0. & $\because \div$ & 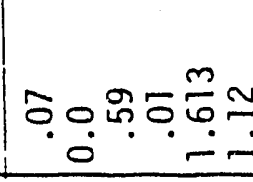 & 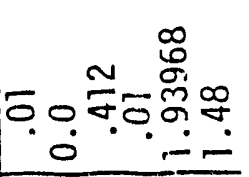 \\
\hline 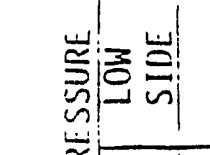 & $:$ & $: 0$ & Ð⿻요 & 赖 & 요 & 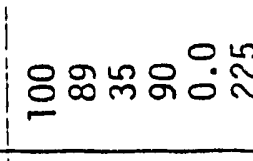 & 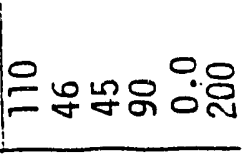 \\
\hline 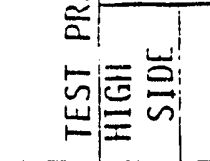 & 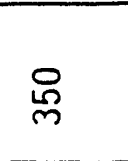 & 峞怘 & 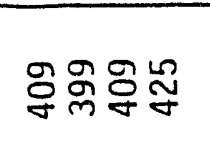 & 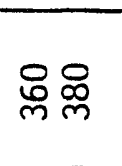 & 宇戹 & 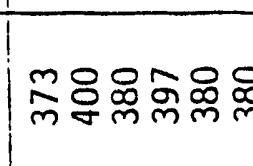 & 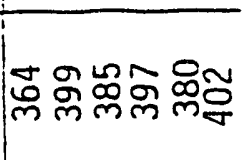 \\
\hline 点岕 & $\sum_{\infty}^{\infty}$ & 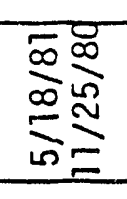 & 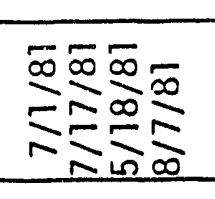 & 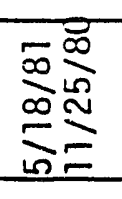 & 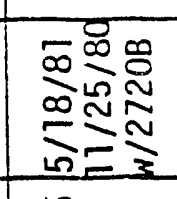 & 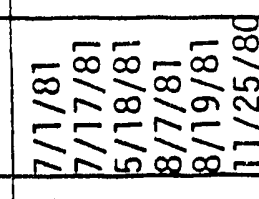 & 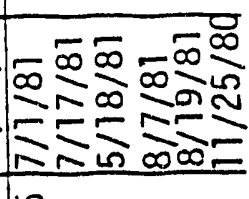 \\
\hline 崖育国 & $\stackrel{2}{9}$ & $\stackrel{2}{9}$ & $\stackrel{n}{a}$ & $\stackrel{n}{\Omega}$ & 2 & 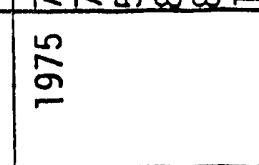 & 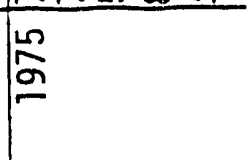 \\
\hline 岂嵌 & 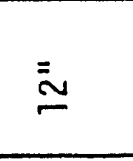 & $\equiv$ & $\cong$ & $\cong$ & $\cong$ & 里 & $\equiv$ \\
\hline 岂峛 & 㩆 & 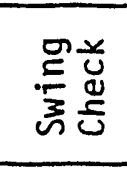 & 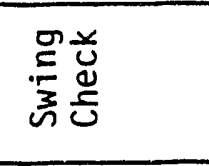 & 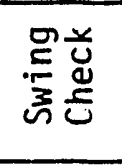 & 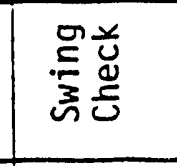 & 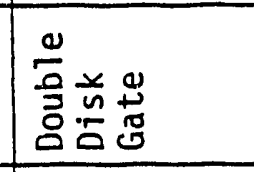 & 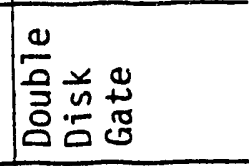 \\
\hline 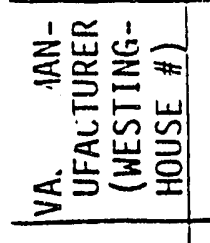 & 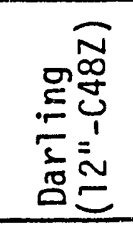 & 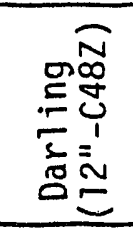 & 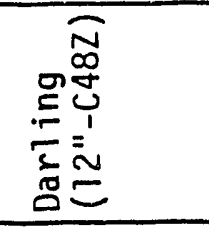 & 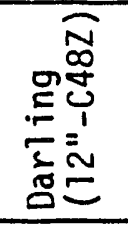 & 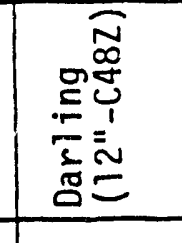 & 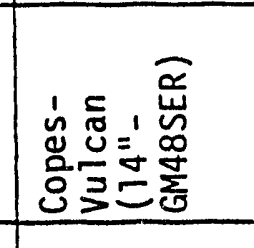 & 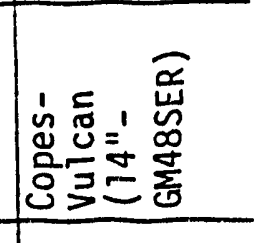 \\
\hline 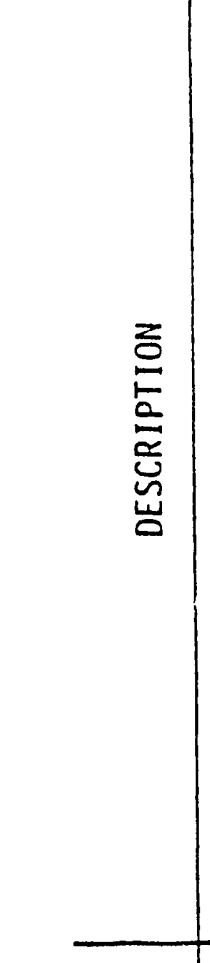 & 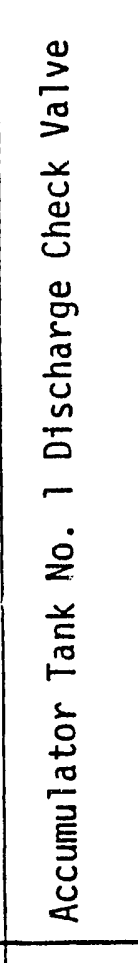 & 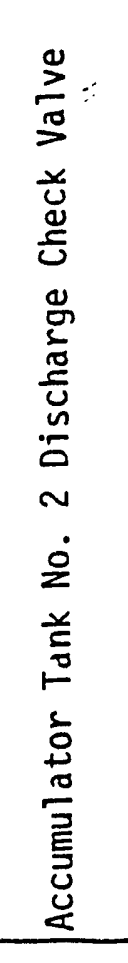 & 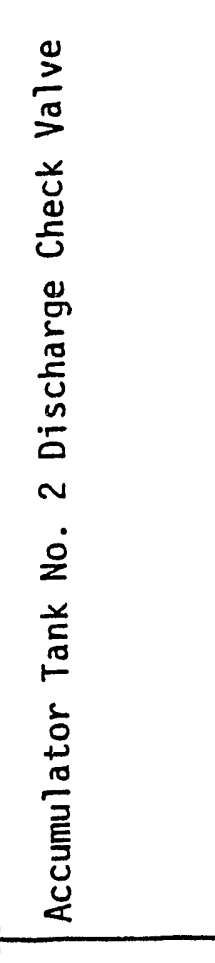 & 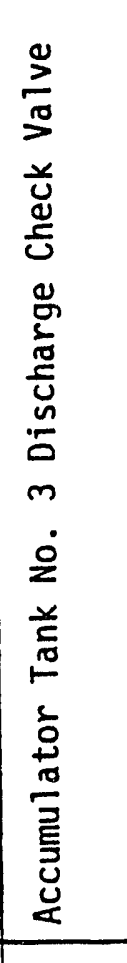 & 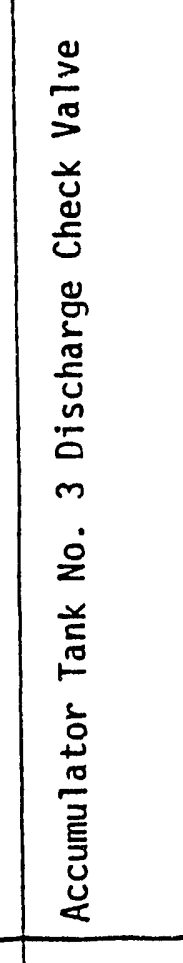 & 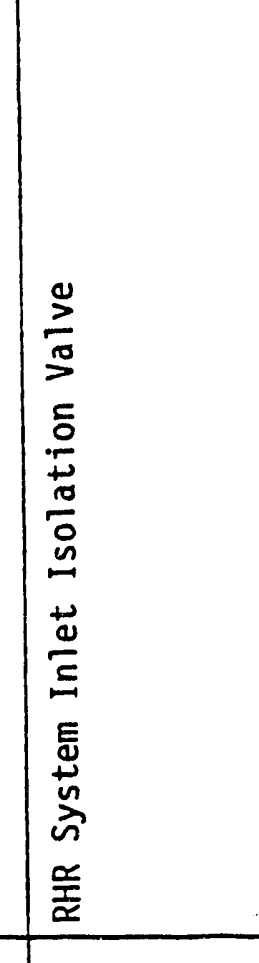 & 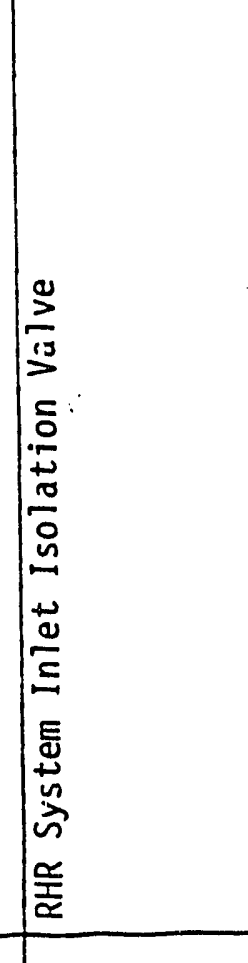 \\
\hline 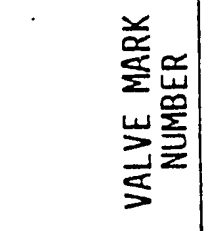 & 倠 & $\begin{array}{l}\frac{\infty}{0} \\
\frac{1}{\omega} \\
\dot{\sim}\end{array}$ & $\frac{⿱}{\vdots}$ & 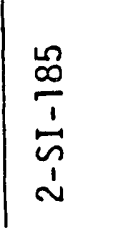 & $\frac{\underline{\omega}}{\frac{\vec{a}}{\dot{a}}}$ & $\mid \begin{array}{c}8 \\
\stackrel{8}{N} \\
\\
\frac{\partial}{2}\end{array}$ & 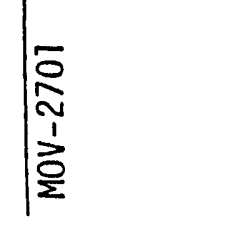 \\
\hline
\end{tabular}




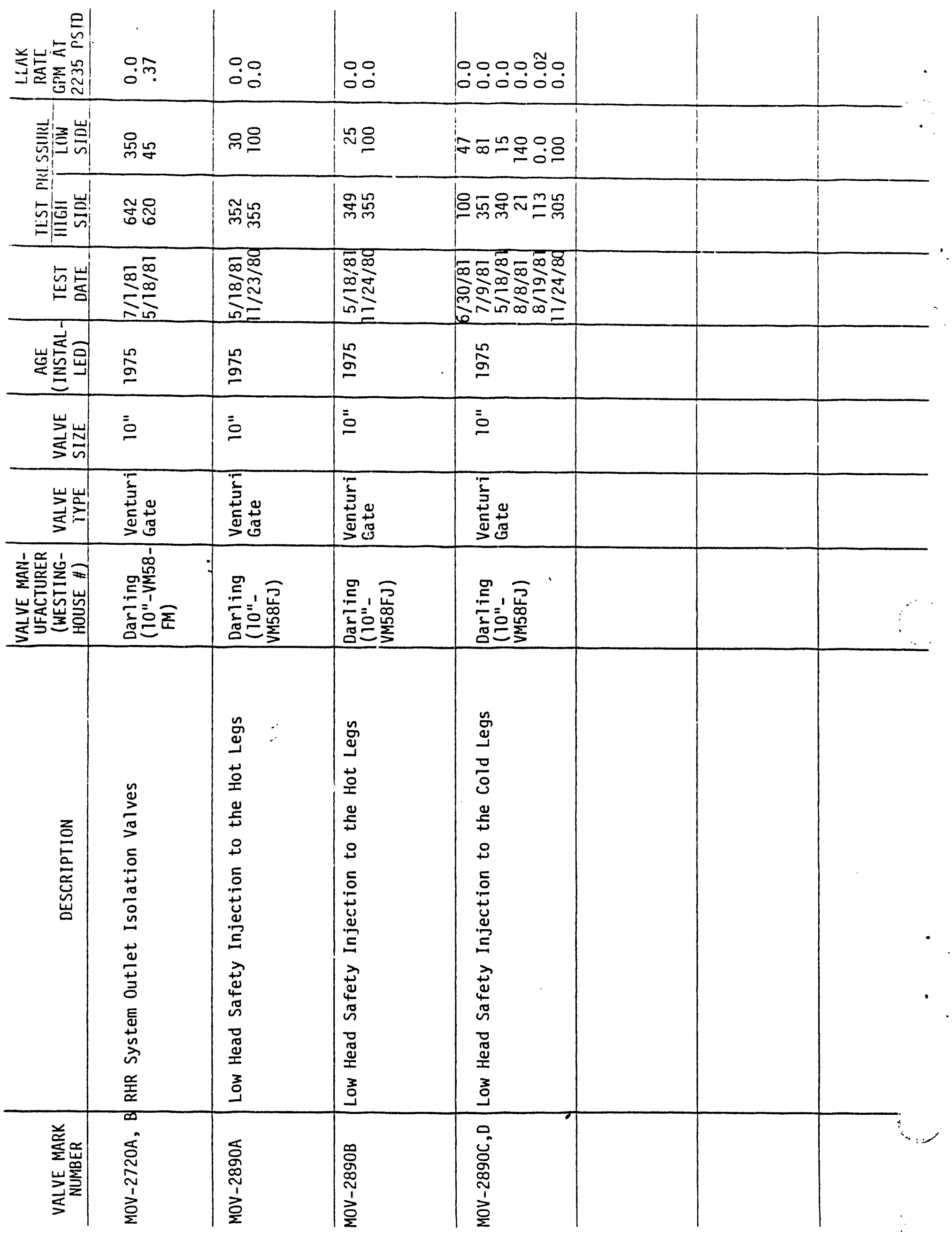


i.

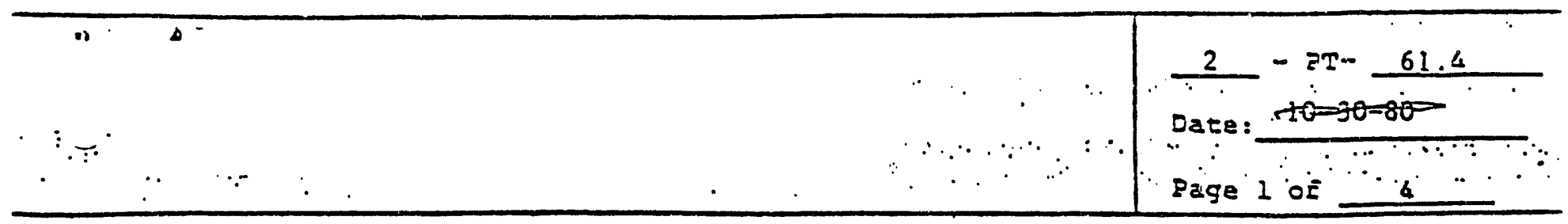

$---$

TILE: RCS PRESSURE ISOLATION VALVES - LEARAGE TEST

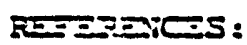

$\because \because \cdots \quad+\frac{1}{-} \cdot$ ASME Section XI, SubsectIon.IWV

2. T.S. $4.4 .6 .2 . \dot{2}$

$\because \because 3012050-6 M-94 \mathrm{~A}, 96 \mathrm{~A}, .96 \mathrm{~B}$

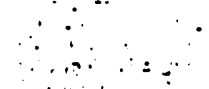

$\because \because \therefore$

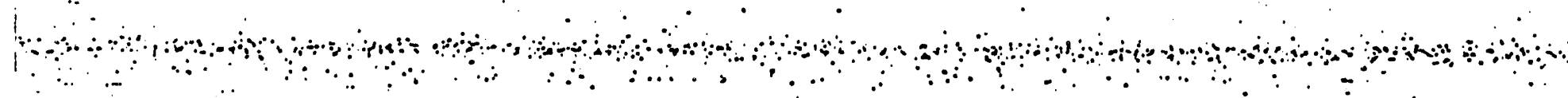

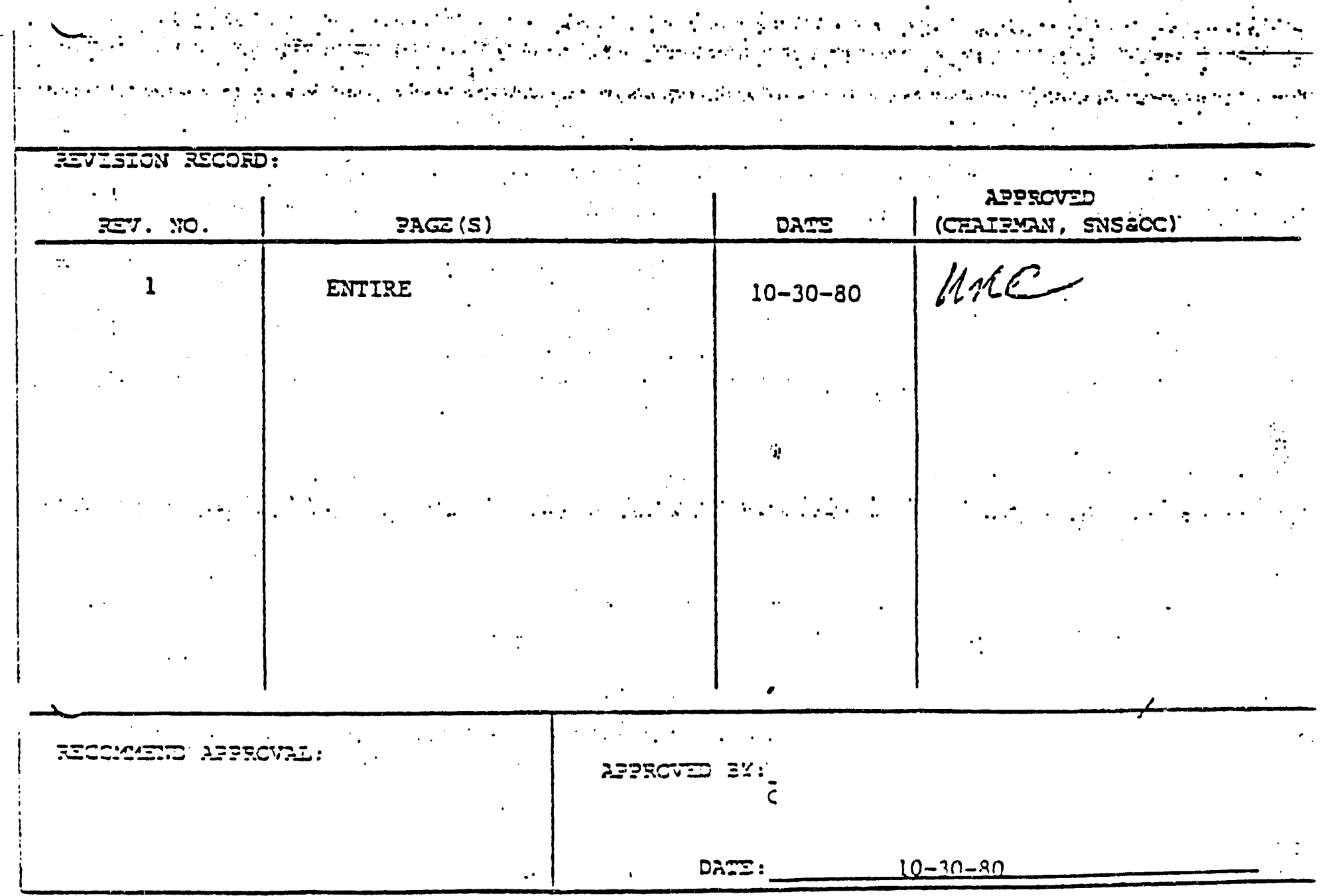




\subsection{Purpose}

1.1. To verify that each reactor coolant systen pressure isolation valve is within its limit:

a.: At least ouce per 18 months.

b. Prior to entering Mode 4 whenever the plant has been in cold stutdown for 72 hours or more and if leakage testiag has not been performed in the previous 9 months. Prior to returning the value to service following maintenance repair or replacement work on the valve:

d. Within 24 bours following valve astuation due ... autonatic or manual action or flow through the valve:

-

$\because$

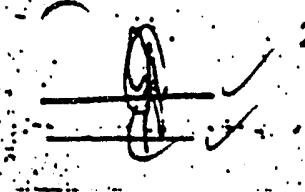

2:0. Initial Conditions

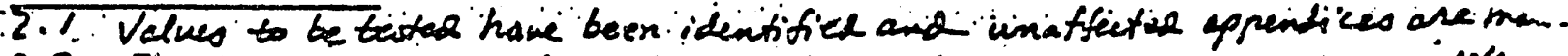

2.2 The test appacatus shown in attachment 6.1 is available and . $\because N / 4$. ready for use.

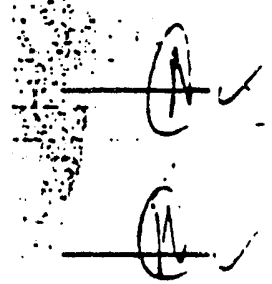

2.3 Two NQC pressure gauges will be required (one for the test Rito and an additional gauge) with a range of about $0-3000$ psi. NOTE: A LOWER RANOS MAT LE USED IF SYSTEN PRESUURE IS LOWNR.

2. 4 A bucket and hose may be required to collect the water from the test rig.

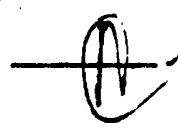

2.5 A calibrated container is ayailable to measure the amount of water bled off.

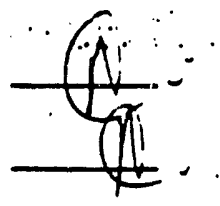

2. A stopwatch is available.

2. Obtain or note any RhP that may be required for each value being tested.

2.8 Notify the shift supervisor of the inpending test and coordinate its performance through him. 


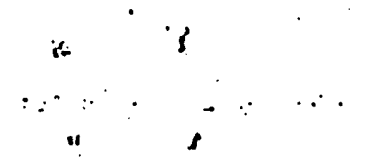

$2-\mathrm{PT}-61.4$

Page 3 of 4 $10-30-8 \theta$

$\underline{\ln i r i 31 s}$

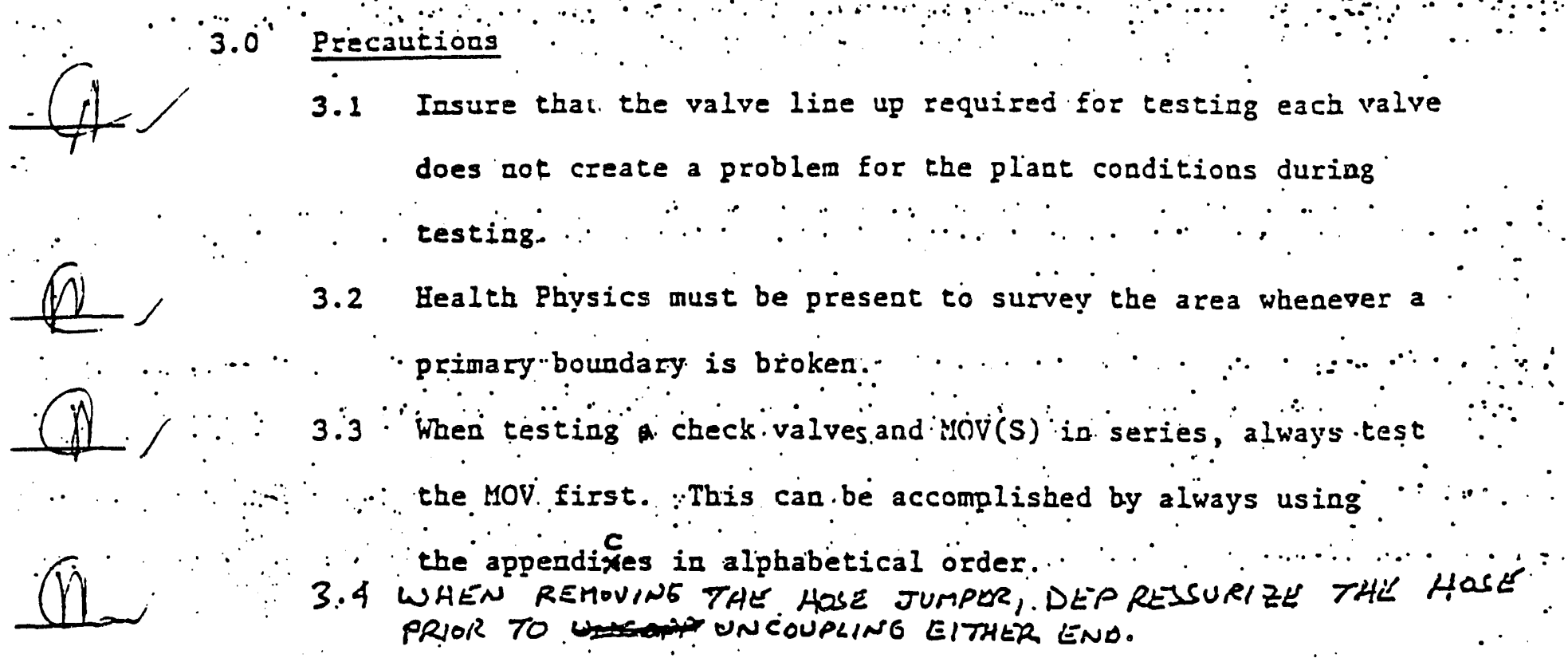

\&Ay

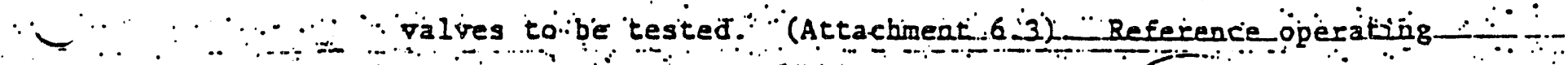

4.2 Record the initial position of each valve during the performance of Step ' 1 on the individual instructions (record beside each valve on the diagram). After, testing, retum the valves to their original positions.

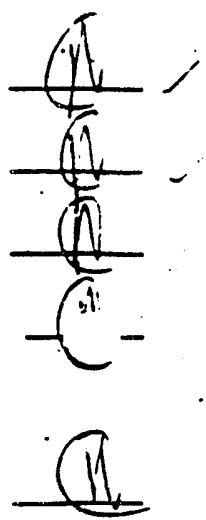

$4.3^{\circ}$ on esch individual instinction sheet, record the following:

4.3.1 Signature and date.

4.3.2 Equipmeric Q.A. number(s).

4.3.3 Any remarks which may, be helpful in the evaluation of test results :

4.3.4 The boundary leakage for eacil valve tested. 
Inicials

\subsection{Instructions (cont.)}
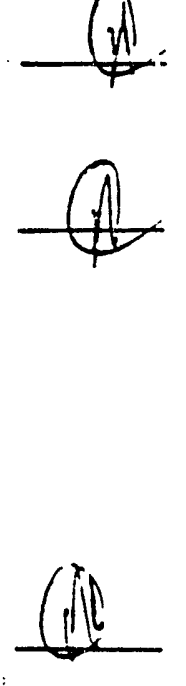

\subsection{Acceptance Criteria}

5.1 All valves tested (except MOV-2700, MOV-2701, MOV-2720A, and MOV-2720B) had a corrected leakage rate of less than $1 \mathrm{gpm}$. NOTE: If only the RHR isolation valves were tested, "N/A" Step 5.1.

5.2 MOV-2700, MOV-2701, MOV-2720A and MOV-2720B had a corrected $\because$. leakage rate of less than $5 \mathrm{gpm}$.

NOTE: If none of the RHR isolation valves were tested, wark Step 5.2 "N/A".

6.0 Attachments

6.1 Test RIG diagram

6.2 Reference OPs and ITIs

$x$

6.3 Valve testing procedures 
Utility G

$\vdots$ 
Utility $G$.

INSERV ICE TEST ING OF VALVES IN

NUCLEAR POWER PLANTS

SURVEY SHEET

NRC TASK \#

$636 T-4$

Please provide the following information:

1. Question:

What version, year, and addenda, of the ASME Boiler and Pressure Vessel Code, Section XI is implemented for "in service testing requirements" for your facility?

Reply:

Utility $G$ is committed the 1974 eddition of section XI, as addended to the sumer of 1975 .

2. Question:

List all "Category A" primary pressure isolation valves, (Event "V" Valves) in your facility for which the applicable edition and addenda of the ASME Boiler and Pressure Vessel Code, Section XI; Technical Specifications; or NRC orders, require periodic leak testing. Provide valve name, manufacturer, identification number, age, type, and size.

Reply:

Category "A", Event $V$ Interfacing Systems LOCA, pressure isolation valves:

HPSI Header Check Valves, (HPSI-17, HSI-27, HSI-37) 14 IN., 1500\# Atwood \& Morrill, 10 years old.

LPSI Header Check Valves (LSI-12, LSI-22, LSI-32) 10 IN., 1500, Velan, 10 years old, Velan No. P-346-93.

LPSI Header Stop Valve (LSI-M-11, LSI-M-21, LSI-M-31) 8 IN., 150CA, Velan/Limitorque, 10 years old, Velan No. P-34576.

HPSI Header Check Valves (HSI-61, HSI-62, HSI-63) 10 IN., 1500\#, Westinghouse, Model \# 10000 ICS 990000 (DO/ZO), new valves in 1981.

2a. Question:

of the valves listed above, provide a history of the in-service leak testing they have received. Provide test medium, test pressure, and leak rates observed. List those valves, found to be deficient during testing. Include the number of deficléncles observed for each valve over its service life to date. Describe each deficiency, and the corrective action taken. 
Reply:

These valves are required to open for emergency core cooling and the system is maintauned at a pressure higher than the containment design pressure, the systems are seismic class 1 and are protected from high energy line brakes and missels. In addition, these lines are designed to circulate cuntaminated ccolant through a closed system outsicie of containment. Regulatory guide 1.141 addresses the exemption of this type of system from leak testing. Section IWV-3421 of the ASME Code (S1978), also states that "Valves which function in the course of plant operation in a manner that demonstrates functional adequate seat tightness need not be leak tested". Significant leakage into the ECCS System shows up as a loss of RCS inventory and it may be confirmed by ECCS pressure or flow instrumentation. Leakage paths may also be determined by checking line temperatures during reactor operation and by venting the RCS to containment during the class "A" leak test.

In 1975, valves, LSI-12, 22, 32 were suspected of leaking and the seats were blue checked and found to be satisfactory. In 1981, valves LSI-22 and LSI-32 were opened, the seats were blue checked, and they were both found to be satisfactory.

The safety injection system was modified in 1981 to assure an intersystem leakage rate of less than $15 \mathrm{gm}$; assuming the failure of a single check valve. A new check vaive was added to each safety injection system train. Prior to start up each train was tested to quantify valve leakage. All systems were found to be satisfactory. These valves will be leak tested each refueling outage and the systems are checked for pressure build up prior to the monthly functional test of the motor operated isolation valves: Additional specific information is included in this package.

2b. Question:

of the valves listed in 2., above, list those which at some time during their in-service life to date have missed a required in-service leak test. For each omission, describe the circumstances which caused the leak test to be omitted.

Reply:

Not applicable

3. Question:

Provide a list and description of the various testing methods utilized to comply with ASME Section XI, as it applies to leak testing of "Category A" valves at your facility. Include sketches of equipment used, together with test piping diagrams, and instrumentation types and locations. Also, include copies of operating procedures used for leak testing, together with examples of logs, records, or other documentation utilized to record the testing data for each valve type. 
Reply:

The following procedures are attached for information on Utility G leak testing methods.

Valve Testing Program (currently under revision)

Class $B$ \& C Leak Testing Procedure

Component Cooling System Leak Test Procedure

4. Question:

What problems have been encountered in your facility with applicable in-service leak testing requirements and procedures?

Reply:

We have found that the Codes and Standards lack specific information necessary to justify the exemption of ECCS containment isolation valves from class "C" testing. Leak testing requirements are not delineated in a direct, concise fashion. Section XI does not have the explicit information needed to classify category "A" valves.

4a. Question:

To what extent has personnel exposure to radiation presented problems in meeting in-service leak testing requirements?

Reply:

Radiation exposure is a problem when repairs have to be made to meet strict leakage rates in systems that circulate reactor coolant.

4b. Question:

Has the availability of personnel qualified to perform in-service leak testing, presented problems or caused in-service leak testing to be delayed?

Reply:

MY has not had a problem with the availability of personnel necessary to perform in-service leak testing.

4c. Question:

Has component accessibility presented problems in performing in-service leak testing?

Reply:

Component accessibility has not been a major problem in leak testing. 
4d. Question:

Has the original design of the facility, in regard to the availability and location of test taps or orifices, been adequate to allow performance of in-service leak testing?

Reply:

Original plant designs offered limited test taps and vents. Systems have been modified and a few should be modified in the future.

4e. Question:

Have documentation requirements been restrictive to an extent you consider umecessary? Explain.

Reply:

Documentation requirements have not been extremely restrictive or excessive.

4f. Question:

Has in-service leak testing been hindered by the availability of test equipment or procedures?

Reply:

Leak testing procedures and equipment have been updated as necessary.

4g. Question:

Has interpretation of ASME Section XI presented problems in establishing your in-service leak testing program?

Reply:

Our leak testing program was developed in accordance with appendix " $\mathrm{J}$ " of the Code of Federal regulations. Variations between our original program and ASME requirements are being addressed in revision to the ISI program. These revisions will clarify the descrepancies between the codes and the existing valve testing program.

List and describe any additional problems encountered. (See question 4).

5. Question:

List -- as a function of valve type, service, size, age, and manufacturer - the allowable leak rate you consider practical from the standpoint of measurement and valve repair. 
Reply:

The valves addressed in question two should be able to maintain a leakage rate of less than $5 \mathrm{gm}$. Valves HSI-17, 27, 37 were exempted from this rate following the installation of HSI-61, 62, 63. Their leakage rates are not stated and they are maintained as a thermal barrier only. Cumulative leakages in excess of $15 \mathrm{gpm}$ can be handled by the LPSI relief system.

6. Question:

Provide examples of design reports or comparble documentation which delineates the mamer in which ASME Sections III and XI code requirements for valves were met at the time of the original installation.

Reply:

Maine Yankee was not constructed to ASME Section III or to Section XI requirements. See the inclosed copy of Valve Specification YA-GEN-3.

7. Questions:

Provide examples of applicable portions of Plant Operating Manuals, Inservice Inspection Manuals, Tectnical Specifications, or comparable documentation which outlines in-service leak of "Category A" valves in your facility.

Reply: :

The last revision to our valve testing program is inclosed.

The preceding information in submitted to Joth G. Collett, to aid in his analysis of vlave testing programs and related problem at nuclear power stations, (NRC Task 非6367-4). All responses were based on the interperatations of the plant I.S.I. cooridnater and they do not express the opinion of Maine Yankee's management. The information if supplied in good faith, soley for the use of Mr. Callett, and the information should be handled accordingly.

December 11. 1981

Plant ISI Coordinator 
EDCR TITLE: Safety Intection System Modificartons

COGNIZANT ENGINEER:

SUMMARY :

REASON FOR CEANGE:
This EDCR Installs a new $10^{\prime \prime}$ chect valve in the safety infection lines to each loop.

USNRC lecter to all LWR L1censees, dated $2 / 23 / 80$ identiffed a potential intersystem loss-of-coolant accident which could result in a lOCA outside containment. The situation postulared is the fallure (as pressure isolation boundaries) of two in-serfes check valves. This situation, as it applies to Maine Yankee, invisives the LPSI/HPSI headers.

Additional verbal correspondence with the NRC, has required a comitment for periodic inspection and leak testing of these check valves with strlagent leak rate requirements ( $\leq 5 \mathrm{gPm}$ ). The 14" hard-seat check valves close to the loop were not designed to be leak t1ght, bue mainly a thermal barrfer. It may be difflcult to meet the new leak race requirements on thase valves. Because these valves are in a relatively high radiation area, valve maintenance would lavolve considerable personnel exposure.

The addition of the new check valves will preclude the testing requirements of the 14" hard-seat valves. The new values will have provistons for leak testing and will be locaced in relatively low radiation areas. Additionally, provisions will be made for leak testing the upstream 10" LPSI check valves as these valves will also have to be Inspected and tested.

This change will 1nvolve the installation of three (3) new 10" swlng check valves. Each valve wlll be located in the 10" safety infection line between the manual header Isolat on valve (HSI-16, 26 or 36 ) and the penetration for the new 2" safety infection recircularton line (see EDCR 81-3). The valves will be located in relatively low radiation areas to facilftate 1nstallation, perlodic leak testing and future malncenance. The valves for Loops 1 and 3 will be located fuse inside the crane wall dependenc upon accessibility and radiation levels. In Loop 2, the 10" header runs adfacent to a concrete wall making installation extremely difficult. For this reason, the Loop 2 check valve w11l be located in the annulus. 


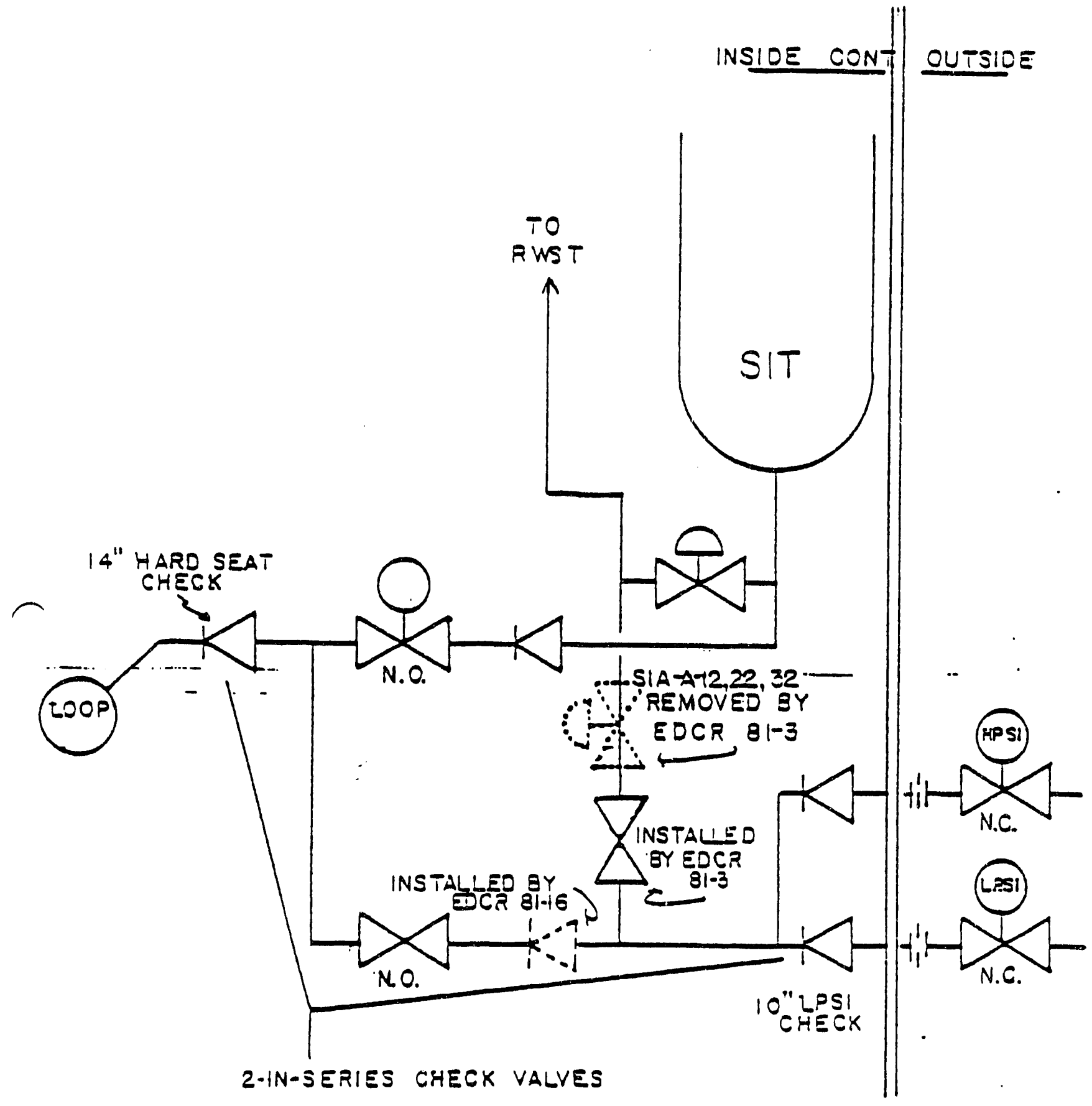


MEMORANDUM

TO

FROM
Company or Location

Company of Location
LEAK TEST I I-12,22,32

FILE

SUBJECT

The following leak tests were performed while hydro testing the safety injection system for EDe 81-16 modifications. A positive displacement pump was used to pressurize the system to 2,475 sig. The pump displacement was verified to be $1 / 33 \mathrm{gal}$. liquid per stroke. Each complete cycle of the pump is two strokes.

Loop 3

Makeup during the hydro test was $.07 \mathrm{gal} / \mathrm{min} .$. The darkened values on the sketch indicate the hydro boundries. Drain value LSI-35 was closed during the hydro and opened at the end of the hydro test, to check for leakage across check value LSI-3Z. On opening LSI-35, the flow did not increase at the pump, and only a slow drip was released from the drain value as air moved into the pipe and displaced liquid.

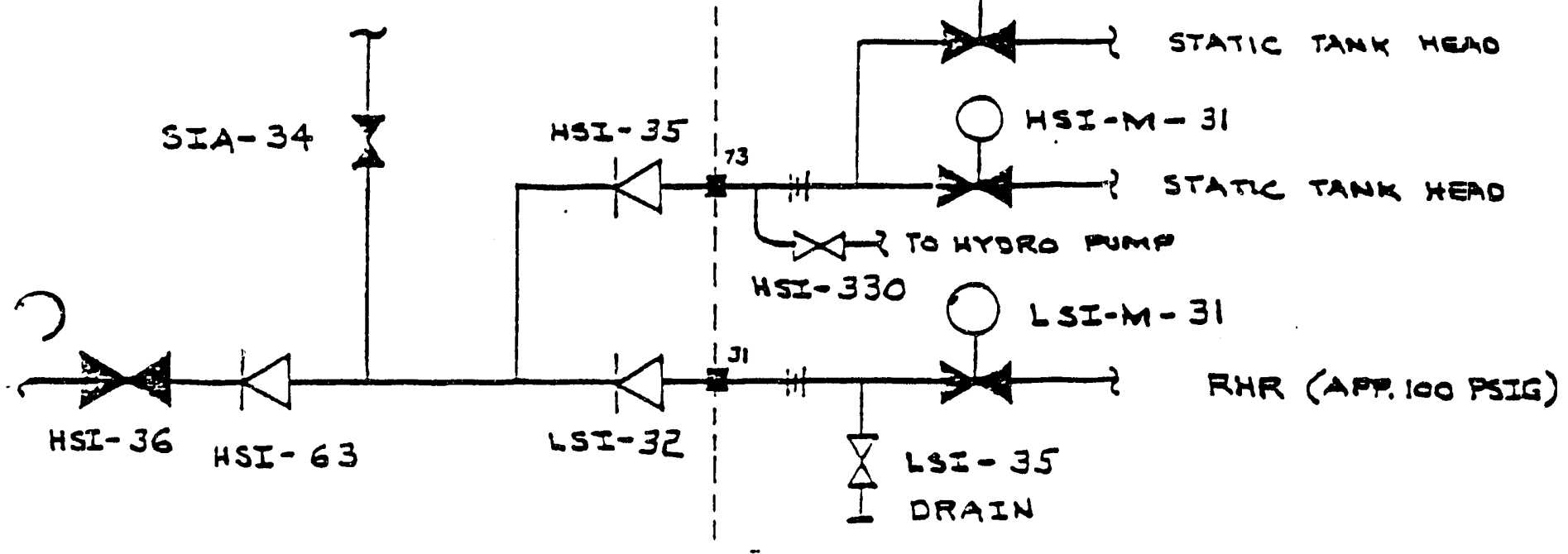


$O_{\text {Loop } 1}$

Make-up during the hydro was $.58 \mathrm{gpm}$. On opening the drain, LSI-15, the make-up was reduced to $.18 \mathrm{gpm}$. Ro significant flow was noted from the drain, and the decrease in flow was do to the check value seating. This indicates that LSI-M-Zl was leaking at - 4 gpm with a 2375 poidifferential pressure across the value.

\section{TEST EOUNDAFY}

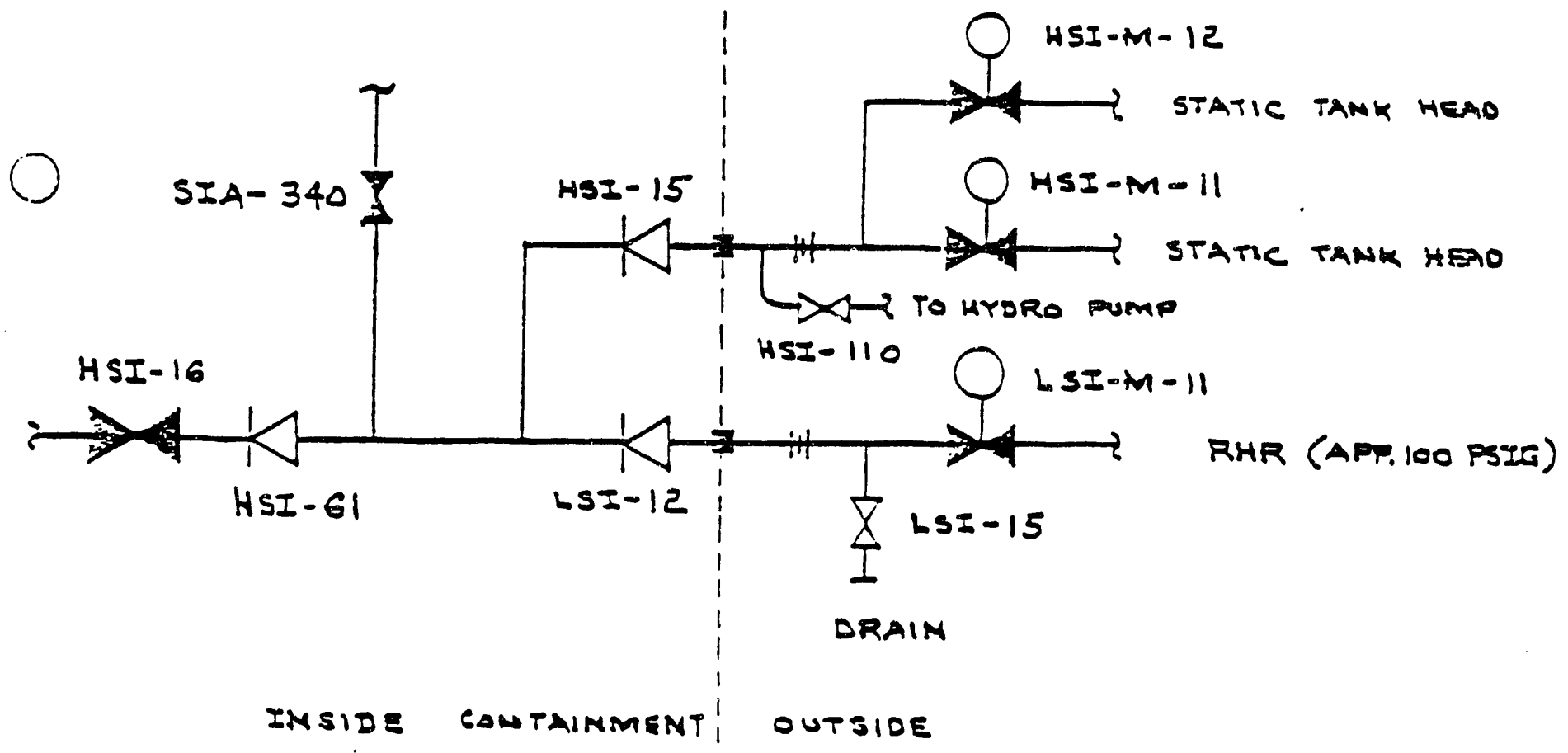




\section{MEMORANDUM}

$\int_{\text {TO }}^{\prime}$

FROM

SUBECT
LEAK TEST I I-12,22,32

FILE

The following leak tests were performed while hydro testing the safety injection system for EDce si-16 modifications. A positive displacement pump was used to pressurize the system to 2,475 psig. The pump displacement was verified to be $1 / 33 \mathrm{gal}$ liquid per stroke. Each complete eycle of the pump is two strokes.

Loop 3

) Make-up during the hydro test was $.07 \mathrm{gal} / \mathrm{min}$. . The darkened values on the sketch indicate the hydro boundries. Drain value LSI-35 was closed during the hydro and opened at the end of the hydro test, to check for leakage across check value LSI-32. On opening LSI-35, the flows did not increase at the pump, and only a slow drip was released from the drain value as air moved into the pipe and displaced liquid.

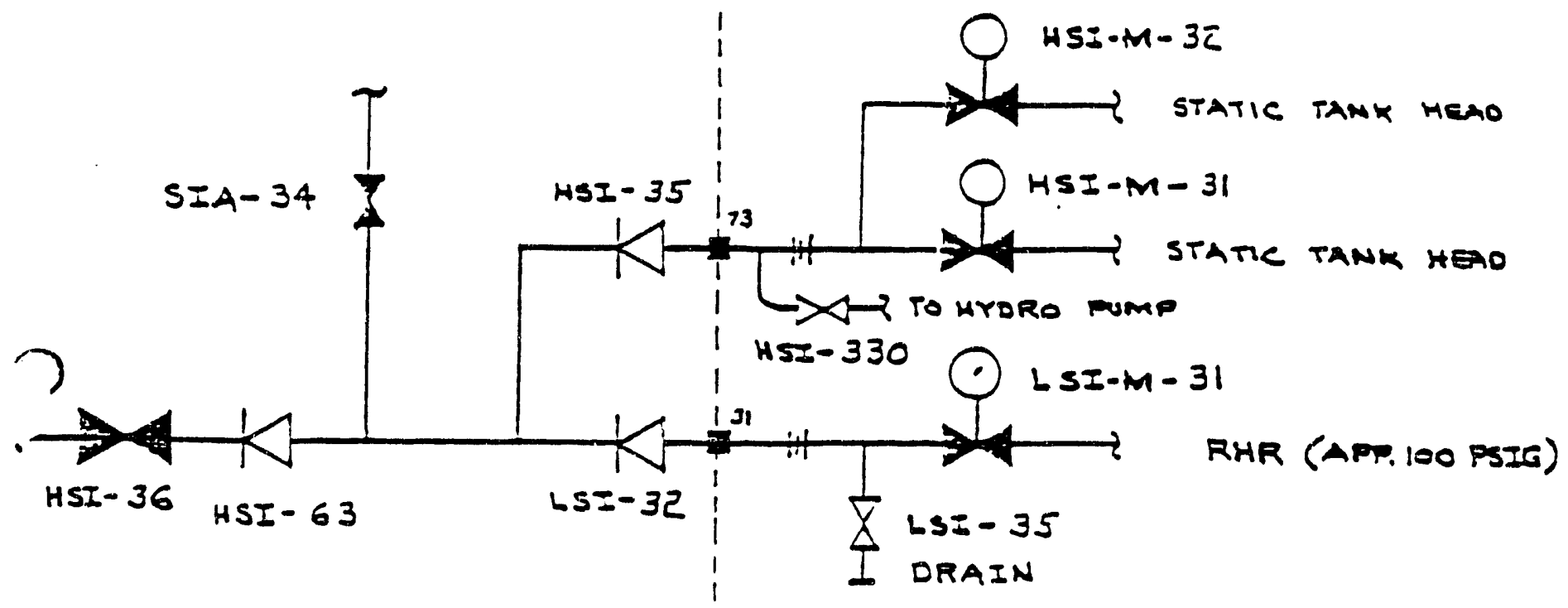


- COMPLEUTED

DATS/TIEE 7/6/81, 2/33.

PSS REVINW

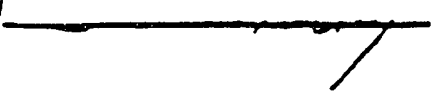

Dept. Bead T- 1 Proc. No. 4-121

Fit. Mar.

50.
Class. Rev. No. 0

Issue Date 716781

Review Date $7 / 6 / 82$

\section{4-121 TEMEORARY IEAR TIST FOR ESI-61, 62\& 63}

\subsection{OBNECTVE}

1.1 To detemine if the valves reet the criteria of passing less than 5 grm each.

\subsection{PRDCAUTIONS}

2.1 Avoid exceedirg $700 \mathrm{psi}$ in the SIATK recire, header (approx. lift pressure for SIA-S-43).

2.2 Do not open ISI-M-11, 21 or 31 to avoid overpressurizing the RFR piping while this test is being conducted.

2.3 If SIA-S-43 lifts open up a flow path to relieve SIATK recire. header pressure.

\subsection{INIEIAL CONDITIONS}

3.1 RCS system pressure equal to or greater than 2260 psi.

3.2 Suitable flow measuring device has been installed for the test on SIA-342. (see sketch)

3.3 Personnel are arailable to inspect for piping leakage.

3.4 Record initial tank levels
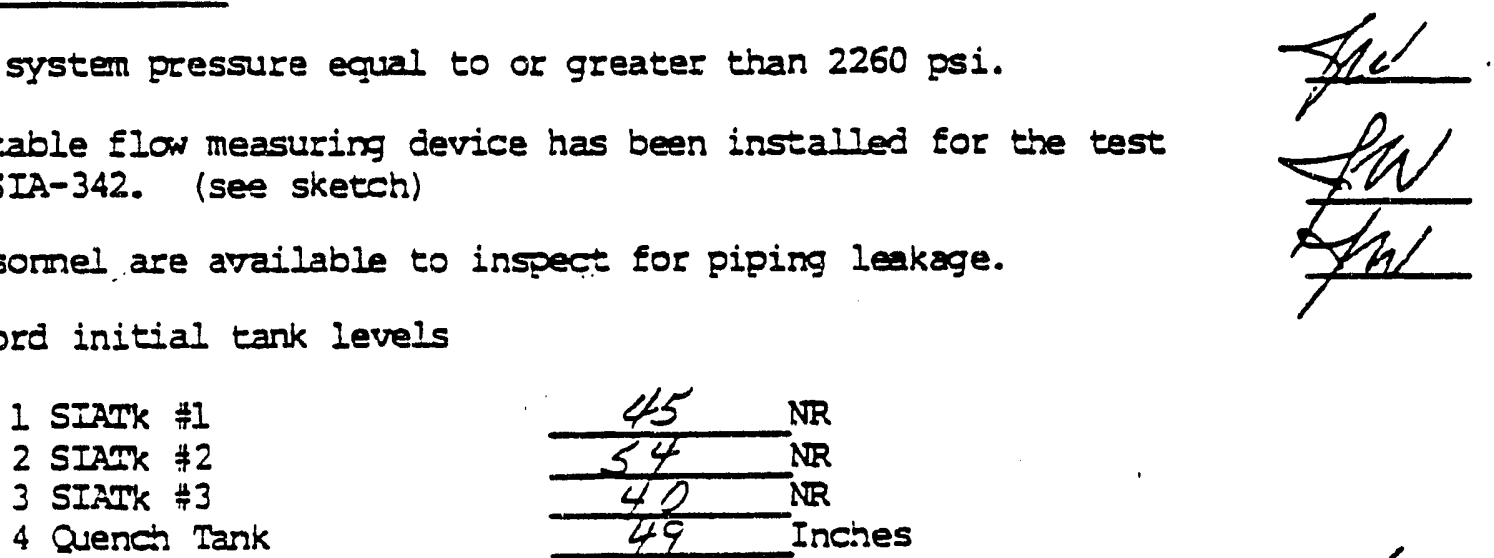

3.5 Stopwatch available to time flaw rate.

3.6 Calibrated container makeup to measure flow.

\section{0 PROCIDTE}

4.1 Verify the following valve lineup:

SIA-A-13

SIA-344

SIA-34I

SIA -340
\#I SIATK fill

*l SIAIK fill isol.

\#I SIAIK hdr drain

\#I SIATK recirc. isol.
Closed

Closed Closed

Closed

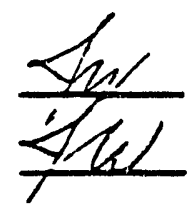


$5 \operatorname{IA-9}-23$

SIA-346

$S I A-342$

SIA-345

SIA-A- 33

$5 I A-348$

$S I A-343$

SIA-347

[SI $M-1]$

ISI-M-27

ISI $-X-3 I$
\#2 SIATK EiII

\$2 SIATK Eill isol.

$\$ 2$ SIFTK bar drain

ㄱ2 SIATK recire. isol.

"3 SIATK fill

\#3 SIATK fill isol.

\#3 SIATk hdr drain

\#3 SIAIK recire. isol.

RER to 100 D 1

RERR to 1000 2

RER to 100 D 3

SIA-M-40 SIATK recire. hdr. Stop
Closed

Closed

Closed

Closed

Closed

Closed

Closed

Closed

Closed

Closed

Closed

Closed

4.2 To detemaine the leakage past HSI-6I:

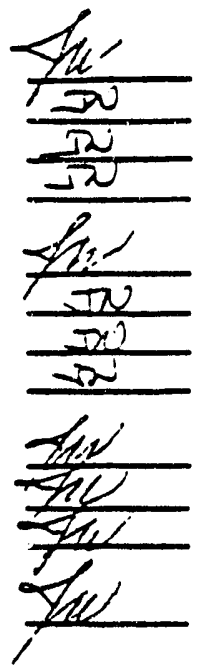

4.2.1 Open SIA-340 \#I SIATK Iecirc. isol.

Open valve $\# 1$ on test gage

Slowly open SIA-342 to full open

4.2.2 Osing the calibrated container and a stopwatch detemine the leakage past ESI-6I.

$\frac{\frac{\pi}{N U}}{\frac{\pi}{N}}$

Leak Rate $.0526 \mathrm{gpm}$

4.2.3 Close SIA-340 \#1 SIATK recirc. valve

$\pi$

4.2.4 Close SIA-342 \#2 SIAIT hdr. drain

4.3 To detemine the leakage past ESI-62:

4.3.1 Open SIA-345 \#2 SIATK recirc. isol.

open valve $\$ 1$ on test gage

Siowly open SIA-342 to Eull open

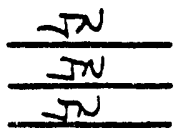

4.3.2 Using the calibrated container and a stopwatch detemine the leakage past ESI-62.

Leak Rate, $0277 \mathrm{gpm}$

4.3.3 Close SIA-345 \#2 SIATK recirc. valve

4.3.4 Close SIA-342 \#2 SIAIX hdz. drain

$\frac{\pi}{\pi}$


Proc. No. 4-121

Rev. No. $\frac{4-121}{0}$

)

4.4 To detemine the leakage past ESI-63:

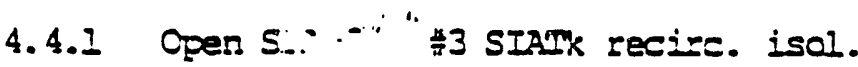

open valve

Slowly open SIA-342 to full open

4.4.2 Using the calibrated container and a stopwatch detemine the leakage past ESI-63.

$\frac{\frac{\pi}{N}}{\frac{\pi}{N}}$

Leak Rate

4.4.3 Close SIA-347 \#3 SIAIK recire, valve

4. 4.4 Close SIA-342 2 SIATk har. drain

$\frac{\pi}{\pi}$

\subsection{FINAL COADITIONS}

5.1 Remove flow measuring device flom SIA-342 and store in ISC shop in PAB.

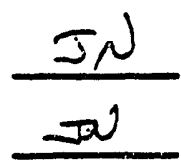

5.2 Lock closed SIA-342.

5.3 Record final levels of

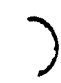

$$
\begin{aligned}
& 1 \text { SIATK \#I } \\
& 2 \text { SIAIK \#2 } \\
& 3 \text { SIATK \#3 } \\
& 4 \text { guench Tank }
\end{aligned}
$$

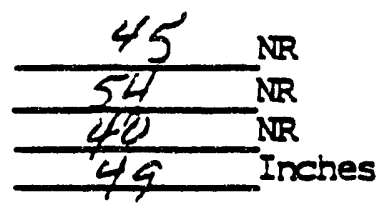

Compare these to levels in Step 3.4 to check for additional leakage patiways.

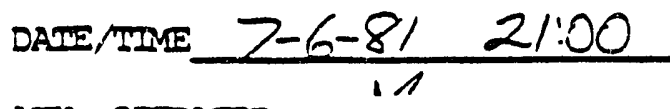

AUX OPERATOR.

SOS REV.

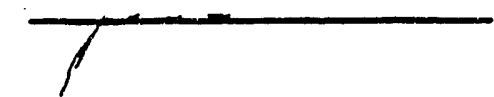


כ

Proc. No. 4-121

Rev. No. $\frac{4-121}{0}$

TIMTEORARY LEAR TIST FOR ESI-61, 62\& 63

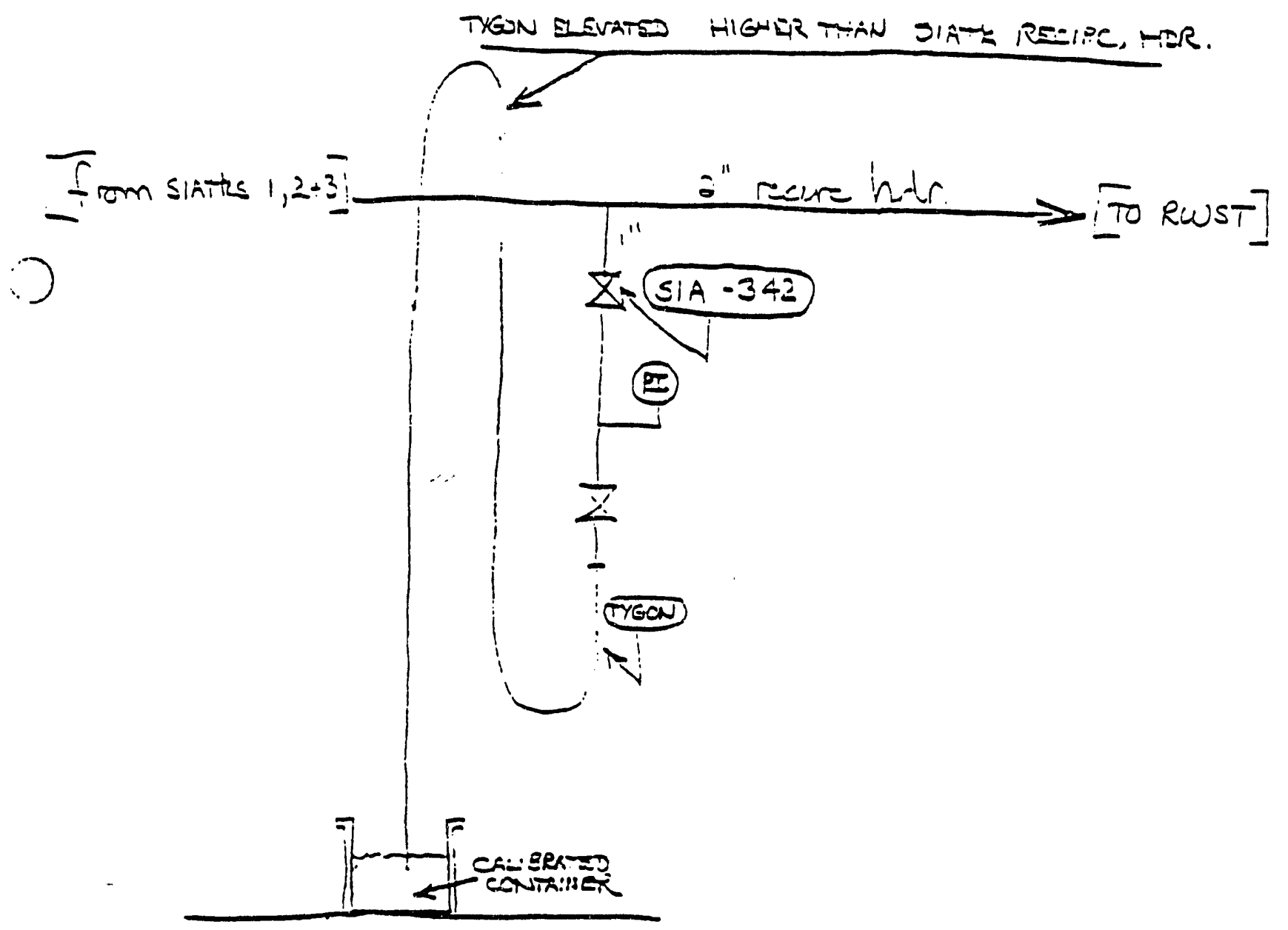

o 
Utility $H$ 
Mr. John Collette

$E G$ and $G$ (Idaho)

1284 Azalea Street

Idaho Falls, Idaho 83401

Subject: Utility $H$

Leak Rate Methodology

Dear Mr. Collette:

Attached information is provided to represent the typical procedures issued at Utility $H$ for the determination of leak rates on containment isolation valves. The general procedure for leak-rate testing is LTS-900-1 and the specific procedure for one LPCS line is LTS-900-2. A schematic diagram of a typical valve configuration is shown also. The Utility $H$ ESAR Table 6.2.21 indicates all types of valving

configurations for the Utility $H$ containment isolation function. Signt derivatives from this specific procedure would be necessary to obtain leakage information for the various valves in other configurations; the general procedure, however, outlines the approach which would be used.

The activity level at the station is such that higher priority and near-term activities are taking our time and resources just prior to receipt of the operating license. For these reasons, our input has been delayed. I hope this information is still useful to you.

Very truly yours, 


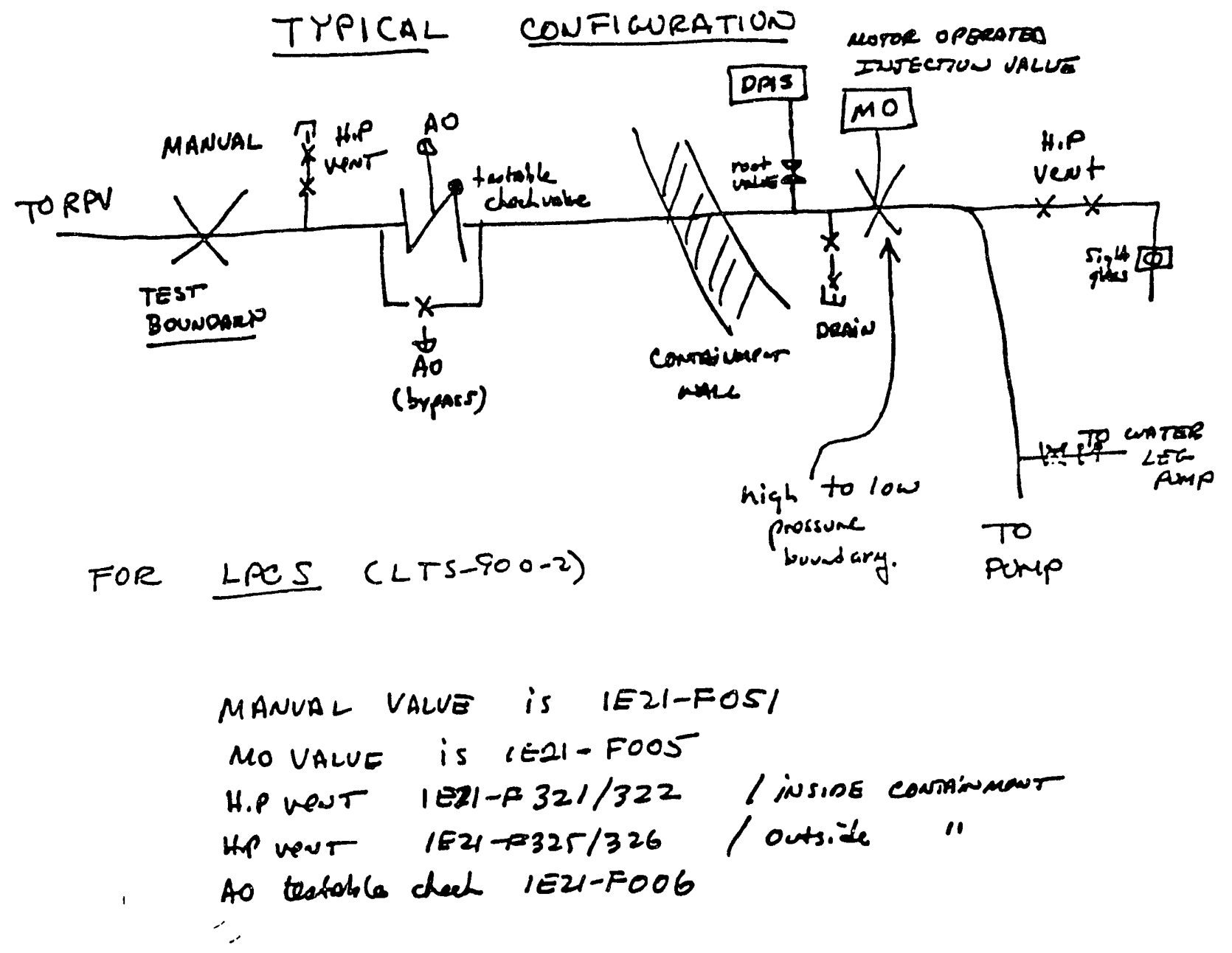


LTS-900-1

Revision 0

Septemoer 10.1981

1

WATER LEAK RATE TEST METHOD

4. PURPOSE

The purpose of this procedure is to outline the metnod to be used to determine tne water leakage of an isolaced volure using a test pump.

B. REEFERENCES

1. fSAR Question 111.86 .

C. PREREQUUISITES

1. The test pump with appropriate noses and fittings $i$; ivitilanle.

U IREC:IIIIUNS

1. Care must de taken when performing these tests at full reactor pressure.

2. The water contained in the volume to be tested snoula de considered contaminated.

E. LIMIIATIONS_ANO ACTIONS

1. All valves to be tested must be closed by normal

- means prior to the test.

F. PROCEDURE

1. Attach the high pressure hose from the test pump discharge to the test connection.

2. Place test pump suction line into caliorated water volume.

3. With the test connection valves closed. start the test. jump and crack open the discharge nose vent valve to rensove any air in the line.

HOIE

Adaitional water may need to de added to fump suction supply. Do not allow pump suction to run arye

4. When the line is full of water.' close the vent ano stop the test pump. Install the cap on the vent. 


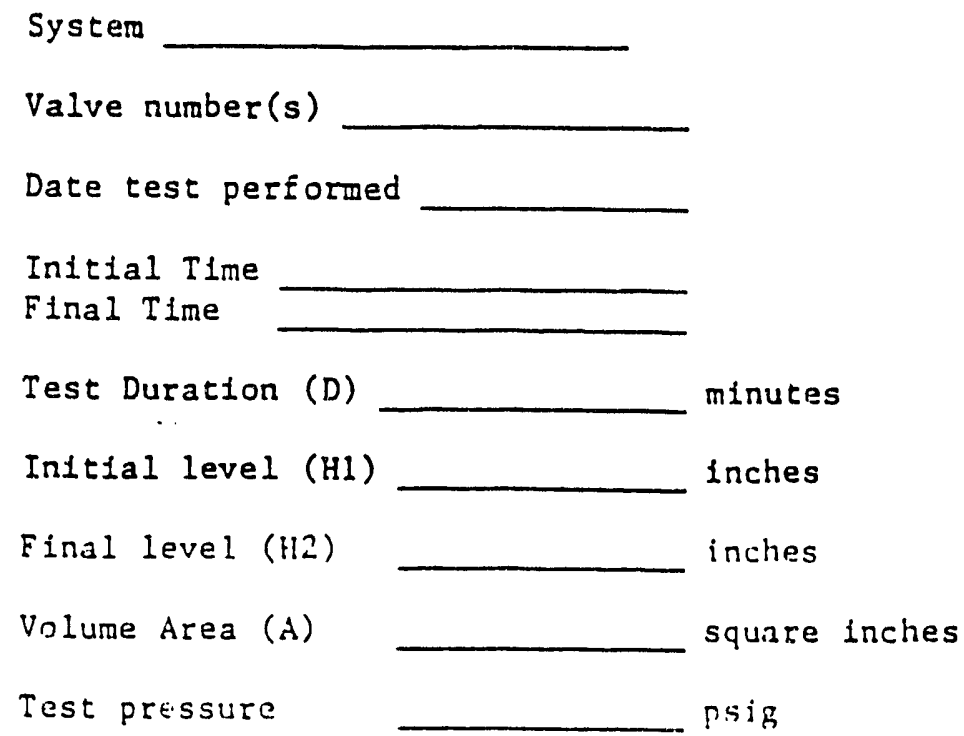

Allowablu leak rate f:.11/min

Calculated Leak Rate $(L)=0.00433 \mathrm{~A}(\mathrm{H} 1-\mathrm{H} 2) / \mathrm{D}$

$=$ $g a 1 / \mathrm{min}$

Remarks:<smiles></smiles>

$\because$

$\div$

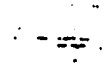

Performed by

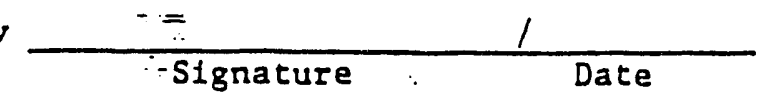

Revlewed by

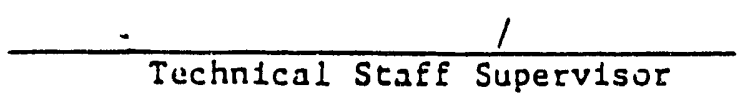

Trend Analysis

NOTE: Notify the Shfft Engineer of the results and verffy that the results are recorded in the Shift Engineers logbook. If the leak rate test falls, notify the Shift Englneer and inftiate a work request to have the valve(s) repalred. 
LTS $-900-2$

Kevision 0

sepremoer 16,1981

1

LOH PRESSURE CORE SPRAY PRESSURE

ISOLATION VALVES LEAK TEST

$1(2) E 21-F 006$ and $1(2) E 21-F 005$

A. PURPOSE

The purpose of this procedure is to outline the method to be used to determine the water leakage tnrough valves $1(2) E 21-F O C O$ and $L(2) E 21-F O C 5$ at full reactor pressure.

8. REFERENCES

1. PEIO M-94 (14-140), LOW Pressure Core Spray System.

2. LTS-9C0-1 water Leak Rate rest Metnod.

C. PSEREIUUISITES

1. The LPCS system shutdown ana not requirea for operation.

2. The reactor shutdown and at atmospheric pressure.

D. PRECAUTIONS

1. During the performance of this test the volume. test pump and line will be at 1000 psig.

2. The water inside the volure should be considered contaminated.

E. LIMITATIONS AND ACTIONS

1. The leak rate limit for each valve is $1 \mathrm{gpm}$ at 1000 psig.

2. This test is required to be performed once per 10 months.

F. PROCEDURE

1. Close LPCS Injection Manual Stop Valve l(2)E2l-Fusl.

2. Open L.PCS Injection Stop Valve $1(2: E 21-F O C S$ at panel $1(2)$ HL 3-P6OL.

3. With the LPCS/RHR A water LEg Pump running verify that the LPCS system is filled oy removing tne pipe plug and cracking open high poine vent valves l(2)E21- 
Utility I 
Mr. Robert A. Clark, Chief

U. S. Nuclear Regulatory Commission

Office of Nuclear Reactor Regulation

Division of Licensing

Operating Reactors Branch No. 3

Washington, D.C. 20555

Reference: Docket No. 50-285

Dear Mr. Clark:

As requested by Mr. C. Trammell of your staff, Mr. John Collett of EG\&G recently visited Utility I's review Event $V$ valve concerns. It is the Utility I's understanding that $\mathrm{Mr}$. Collett has been contracted by the Commission to conduct a study of problems experienced by utilities in testing of Event $V$ valves. During this visit, Mr. Collett left a list of questions for which he desired additional information. The responses to $\mathrm{Mr}$. Collett's questions are attached. Please note that a copy of this information has also been forwarded directly to $\mathrm{Mr}$. Collett.

Please note that in our discussions with Mr. Collett of EG\&G, he clarified his request for completion of the attached survey sheet. He is particularly interested in Event $V$ isolation check valves. None of the valves in the Utility I can properly be referred to as "Event V"; therefore, only those check valves which were called out in the Commission's April 20, 1981 Order for Modification of License have been considered in responding to this survey. It continues to be the Utility I's position that the existence of motor operated isolation valves upstream of the two check valves in each injection line and the fact that these valves are maintained in the closed position throughout normal operation offers a significant difference from the Event $V$ situation described by WASH- 1400 .

Sincerely, 


\section{RESPONSES TO INSERVICE TESTING OF VALVES IN NUCLEAR POWER PLANTS SURVEY SHEET}

\section{Request 1}

What version, year and addenda of the ASME Boiler and Pressure Vessel Code, Section XI, is implemented for "inservice cesting requirements" for your facility?

\section{Response}

ISI program is implemented under ASME Boiler and Pressure Vessel Code, 1974 Edition, with Summer 1975 addenda.

\section{Request 2}

List all "Category A" primary pressure isolation valves, Event $V$, in your facility for which the applicable edition and addenda of the ASME Boiler and Pressure Vessel Code, Section XI, Technical Specifications, or NRC orders require periodic leak testing. Provide valve name, manufacturis, identification number, age, type, and size.

\section{Response}

No "Category A" primary pressure isolation valves (Event $V$ ) exist at the Fort Calhoun Station for which an ISI criteria exists. As required by a Commission Order dated April 20, 1981, the District initiated a leak check program for 8 of our 12 primary system/safety injection check valves. The remaining 4 valves have instrumentation in place to allow continuous monitoring for excessive leakage.

The Commission's Order dated April 20, 1981 (Attachment 1) resulted in an addition to our Techniral Specifications (Sections 2.1.1(12), Table 2.9, and 3.3, Attachment 2) requiring leak tests of 4 Low Pressure Safety Injection (LPSI) system check valves and 4 High Pressure Safety Injection (HPSI) check valves. The HPSI check valves were manufactured by Dresser Industries (see Attachment 3), and the 4 LPSI check valves were manufactured by Mission (now TRW-Mission) (see Attachment 4).

The valves are:

$\begin{array}{lllcc}\text { Mission } & \text { Type } & \text { Size } & \text { Years Since Manufactured } & \text { Years Used } \\ \text { SI-194 } & \text { Butterfly } & 6^{\prime \prime} & 11 & 8 \\ \text { SI-197 } & \text { Butterfly } & 6^{\prime \prime} & 11 & 8 \\ \text { SI-200 } & \text { Butterfly } & 6^{\prime \prime} & 11 & 8 \\ \text { SI-203 } & \text { Butterfly } & 6 " & 11 & 8\end{array}$




$\begin{array}{lllcc}\text { Dresser } & \text { Type } & \text { Size } & \text { Years Since Manufactured } & \text { Years Used } \\ \text { SI-195 } & \text { Poppet } & 2^{\prime \prime} & 11 & 8 \\ \text { SI-198 } & \text { Poopet } & 2^{\prime \prime} & 11 & 8 \\ \text { SI-20I } & \text { Poppet } & 2^{\prime \prime} & 11 & 8 \\ \text { SI-204 } & \text { Poppet } & 2^{\prime \prime} & 11 & 8\end{array}$

\section{Request $2 a$}

Of the valves listed above, provide a history of the inservice leak testing they have received. Provide test medium, test pressure, and leak rates observed. List those valves found to be deficient during testing. Include the number of deficiencies observed for each valve over its service life to date. Describe each deficiency and the corrective action taken.

\section{Response}

Included in Attachment 5 (ST-CV-1, ST-CV-2) is a total history of our "inservice" leak testing of the 8 safety injection check isolation valves. So far, no deficiencies have been found.

\section{Request $2 b$}

Of the valves listed above, list those which at some time during their inservice life to date have missed a required inservice leak test. For each omission, describe the circumstances which caused the leak test to be omitted.

\section{Response}

Since the inclusion of our new Technical Specification (2.1.1(12)), none of the valves 1 is ted above (response to Request 2 ) have missed a required leak test.

\section{Request 3}

Provide a $l$ ist and description of the various testing methods utilized to comply with ASME Section XI, as it applies to leak testing of "Category A" valves at your facility. Include sketches of equipment used, together with test piping diagrims, and instrumentation types and locations. Also, include copies of operating procedures used for leak testing, together with examples of logs, records, or other documentation utilized to record the testing data for each valve type.

\section{Response}

Since our plant has no ASME Section XI "Category A" valves, we have no leak tests for same (one should refer to Attachment 5 for details on the leak testing of the safety injection isolation valves). 
Request 4

What problems have been encountered in your facility with applicable inservice leak testing requirements and procedures?

\section{Response}

We have had no difficulty in complying with our required check valve leak tests, ST-CV-1 and 2 .

Request $4 \mathrm{a}$

To what extent has personnel exposure to radiation presented problems in meeting inservice leak testing requirements?

\section{Response}

Our required check valve leak tests were performed in low radiation areas; approximately .05 manrem exposure was received during those tests.

Request $4 b$

Has the availability of personnel qualified to perform inservice leak testing presented problems or caused inservice leak testing to be delayed?

\section{Response}

Because our leak tests were not ASME Section XI tests, personne] qualification was not a problem.

Request $4 \mathrm{c}$

Has component accessibility presented problems in performing inservice leak testing?

\section{Response}

All testing was designed so that it could be performed outside containment; thus, accessibility was not a problem.

\section{Request $4 d$}

Has the original design of the facility, in regard to the availability and location of test taps or orifices, been adequate to allow performance of inservice leak testing?

\section{Response}

As indicated in the test procedure (ST-CV-1, Page 6), one special test rig was installed. This was in a low radiation area, with adequate accessibility. 


\section{Request $4 \mathrm{e}$}

Have documentation requirements been restrictive to an extent you consider unnecessary? Explain.

\section{Response}

Standard surveillance procedure formats were used but presented no difficulty.

\section{Request $4 \mathrm{f}$}

Has inservice leak testing been hindered by the availability of test equipment or procedures?

\section{Response}

New procedures were prepared for the testing required by the new Technical Specifications, with no delays in testing.

\section{Request $4 \mathrm{~g}$}

Has interpretation of ASME Section XI presented problems in establishing your inservice leak testing program?

\section{Response}

As noted above, ASME XI does not apply to the required check valve tests.

\section{Request 5}

List - as a function of valve type, service, size, age, and manufacturer -- the allowable leak rate you consider practical from the standpoint of measurement and valve repair.

\section{Response}

Our leakage criteria are based on the NRC Order and Technical Specification, Table 2.9 (Attachment 2).

\section{Request 6}

Provide examples of design reports or comparable documentation which delineates the manner in which ASME Sections III and XI code requirements for valves were met at the time of the original installation.

\section{Response}

Copies of the original hydrostatic tests of SI-194, 197, 200, and 203 and SI-195, 198, 201, and 204 are attached (Attachment 6). Our original tests were conducted pursuant to ASME B31.70, not ASME. III or $X I$. 
Request 7

Provide examples of applicable portions of Plant Operating Manuals, Inservice Inspection Manuals, Technical Specifications, or comparable documentation which outline inservice leak testing of "Category A" valves in your facility.

\section{Response}

See Attachment 2 (Technical Specifications) and Attachment 5 (leak rate tests) for examples of our documentation of the required check valve tests. 
ATTACHMENT 1 


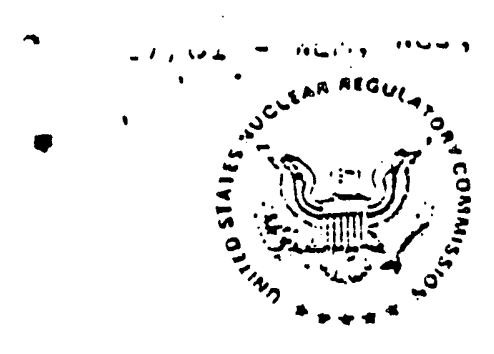

FËFi?e

UNITED STATES

NUCLEAR REGULATORY COMMISSION

WASHINGTON, D. C. 20555

April 20, 1921

Docket No. 50-285

Mr. W. C. Jones

Oivision Manager, Production

Operations

Omaha Public Power District

1623 Harney Street

Omaha, Nebraska 68102

Dear Mr. Jones:

SUBJECT: ORDER FOR MOOIFICATION OF LICENISE CONCERNING PRIMARY COOLANT SYSTEM PRESSURE ISOLATION VALVES

This letter transmits an Order for Modification of License which revises the Technical Specifications for Facility Operating License NO. DPR -40 for the Fort Calhoun Station, Unit No. I Nuclear Plant. The change is a result of the fnformation you provided in response to our 10 CFR $50.54(i)$ letter of February 23, 1980, regarding primary c00lant system pressure isolation valves. Based upon our review of your response, as well is proviously docketed information, we have concluded that a nASH-1400 Event V valve configuration exists at your facilify and that corrective action as defined in the attached Order is necessary.

Attached to the Order for Mosification of License is the Technical Evaluation Report (TER) which supports the Order; and the plant Technical Sracifications wich will ensure public hesl th and safat: over the operating life of your facility. We are aware that there may be editorial corrections to the attached TER. Please note that the Technical specificacicns correctly delineats the requirenents for your facility.

In addition to Evant y yalve configurations, we are continuing our efforts to review_other configurations iocaced at high pressure/iow_ - pressure system boundaries for their potential risk contribution to an intersystem LOCA. Therefore, further activity regarding the broader topic of intersystem LOCA's may be expected in the future. 
A copy of the enclosed Order is being filed with the Office of the Federal Register for publication.

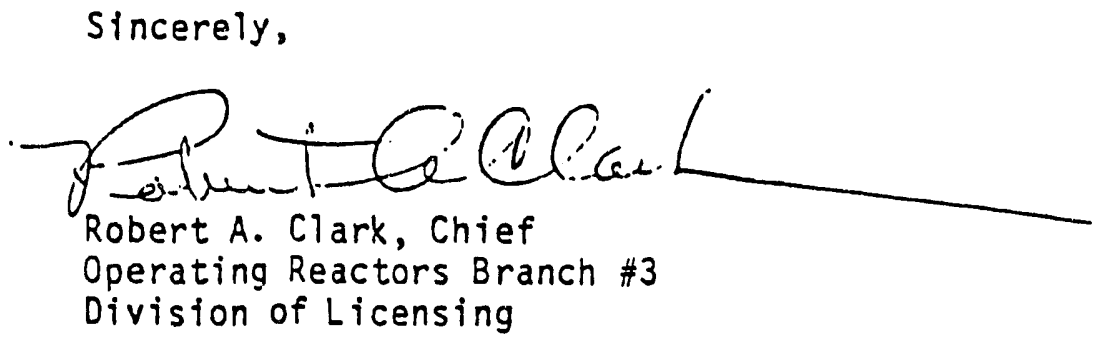

Enclosure:

Order for Modification of License

cc w/enclosure:

See next page 
ATTACHMENT 2

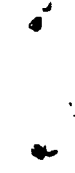

-

$\therefore$

$\therefore$

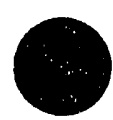




\subsection{LIMITING CONDITIONS FOR OPERATION \\ 2. Reactor Coolant Sustem (Continued) \\ 2.1 Operable Components (Concinued)}

(a) A pressurizer steam space of $60 \%$ by volume or greater exists, or

(b) The stear generator secondary side temperature is less than $50^{\circ} \mathrm{F}$ above that of the reactor coolant system coli leg.

\section{(12) Reactor Coolant System Pressure Isolation Valves}

(a) The integrity of all pressure isolation valves listed in Table 2-9 shall be demonstrated, except as specified in (b). Valve leakage shall not exceed the amounts indicated.

(b) In the event that the integrity of any pressure isolation valve specified in Table 2-9 cannot be demonstrated, reactor operation may continue, provided that at least two valves in each high pressure line having a non-functional valve are in and remain in, the mode corresponding to the isolated condition.*

(c) If Specifications (a) and (b) above cannot be met, an orderly shurdown shall be initiated and the reactor shall be in the cold shutdown condition within 24 hours.

\section{Basis}

The plant is designed to operate with both reactor coolant loops and associated reactor coolant pumps in operation and maintain DNBR above 1.30 during all normal operations and ancicipated transients.

In the hot shutdown rode, a single reactor coolant loop provides suticient hede reroval cupubility for removing decay heat; however, single Eailure considerations require thit two loops be operable.

In the cold shutdown aode, a single rcactor coolant loop or shutdown

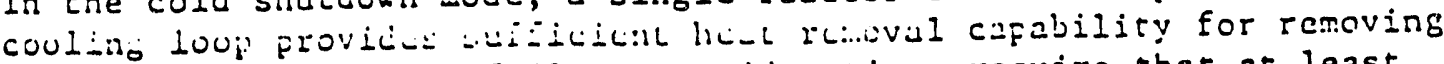
decay heat, but single failure considerations require that at least two loops be operable. Thus, if the reactor coolant loops are not operable, this specification requires two shutdown cooling pumps to be operable.

The requirement that at least one shutdown cooling loop be in operation during refueling ensures that: (1) sufficient cooling capacity is availatile to remove decay heat and maintain the water in the reactor pressure vessel below $210^{\circ} \mathrm{F}$ as required during the refueling mode, and (2) sufficient coolant circulation is maintalned through the reactor core to minimize the effects of a boron dilution Incident and prevent boron stratification.

* Manual valves shall be locked in the closed position; motor operated valves shall be placed in the closed position and power supplies ceeneryized.

Amendment No. 86 , Order dated $4 / 20 / 812-2 b$ 


\subsection{SURVEILLANCE REOUIREMENTS}

3.3 Reactor Coolant Sustem, Stear Generator Tubes, and Other Components Subiect to ASME XI Boiler \& Pressure Vessel Code Inspection and Testing Surveillance (Continued)

Tube Insoection means an inspection of the steam generator tube from the point of entry (hot leg side) complecely azound the U-bend to the top support of the cold leg.

(ii) The steam generator shall be determined OPERABLE after completing the corresponding actions (plug all tubes exceeding the plugging limit and all tubes containing through-wall cracks) required by Table 3-8.

\section{e. Redorting Reouirements}

Following each 1n-service inspection of steam generator tubes, the number of tubes plugged in each steam generator shall be reported to the Comission within 30 days.

(ii) The complete results of the steam generator tube inservice inspection shall be reported to the Commission within six (6) months following completion of the 1nspection. This report shall Include:

1. Number and pitent of tubes inspected.

2. Location and percent of wall thickness penetration for each imperfection.

3. Identification of tubes plugged.

(iii) Results of steam generator tube inspections which fall into Caizory C-3 and rçuire prompt notification of the Commission shall be reported pursuant to Section 5.9.2 of the Technical Specifications prior to resumption of plant operation. The written followup of this report shall provice a doscription of investigations conducted to determine cause of the tube degradation and corrective measures taken to prevent recurrence.

(3) Surveillance of Reactor Coolant System Pressure Isolation Valves

a. Periodic leakage testing* on each valve listed In Table 2-9 shall be accomplished prior to entering the power operation

* To satisfy ALARA requirements, leakage may be measured 1ndirectly (as fron the perforance of pressure indicators) if accomplished in accordance with approved procedures and supported by computations showing that the method is capabie ui dewustrptiug valve compliaice witis the lediaba crlterld. 
TABLE 2-9

\section{REACTOR COOLANT SYSTEM PRESSURE ISOLATION VAL"IES}

Sustem

High-Pressure Safety Injection

Loop LA, Cold leg

Loop 1B, cold leg

Loop 2A, cold leg

Loop $2 B$, cold leg

Low-Pressure Safety Injection

Loop IA, cold leg

Loop $1 B$, cold leg

Loop $2 A$, cold leg

Loop $2 B$, cold leg
Valve No.

$S I-216$

SI-20I

SI -220

SI-204

$S I-208$

SI-195

$S I-212$

SI-198

SI-200

SI-203

SI-194

SI-197
Maximum (a) (b) Allowable Leakage

\section{Footnotes:}

(a) 1. Leakage rates less than or equal to th Dspm ate considered acceptable.

2. Leakage rates greater than $1.0 / 8 \mathrm{pm}$ bur less than or equal to $5.0 \mathrm{gpm}$ are considered acceptable if he latest measuled rate has not exceeded the rate determiget by the previous tist by an amount that reduces the cargin burweon measured leakage ral.e and the maximum pu: :Lisible rulc of 5.0 opin by $50 \%$ or gruates

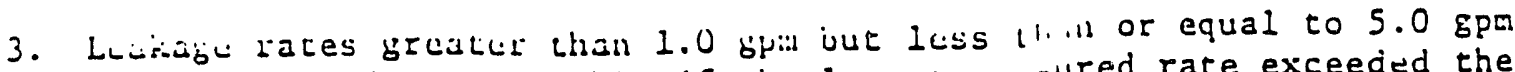
are considered unacceptable if the latest meantred rate exceeded the rate determined by the previous test by an am.unt that reduces the marbin between measured leakage rate and the m...imimum permissible rate

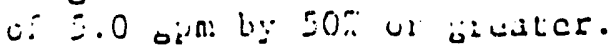

4. Leakage rates greater than $5.0 \mathrm{gpa}$ are considucd unacceptable.

(b) Minimum test differential pressure shall not be liss than 150 psid. 
3.0 SURVEILLHICE REOUIREMENTS

3.3 Reactor-Coolant Svstem, Steas Generacor Tubes, and Other Components Subiect to ASME XI Boiler \& Pressure Vessel Code Insoection and Testing
Surveillance (Continued)

Tube Inspection means an inspection of the steam generator tube from the point of entry (hot leg side) completely around the U-bend to the top support of the cold leg.

(ii) The steam generator shall be determined OPERABLE after completing the corresponding actions (plug all tubes exceeding the plugging limit and all tubes containing through-wall cracks) required by Taile 3-8.

e. Reporting Requirements

Following each in-service inspection of steam generator tubes, the number of tubes plugged in each sream generator shall be reported to the Comission within 30 days.

(ii) The complete results of the steam generator tube inservice inspection shall be reported to the Comission within six (6) months following completion of the Inspection. This report shall include:

1. Number and extent of tubes inspected.

2. Location and percent of wall thickness penetration for each imperfection.

3. Identification of tubes plugged.

(iii) Results of steam generator tube inspections which fall into Cakigory C-3 and rcquire prompt notification of the Comission shall be reported pursuant to Section 5.9 .2 of the Technical Specifications prior to resumption of plant operation. The written followup of this report shall provice a description of investigations conducted to determine cause of the tube degradation and corrective measures taken to prevent recurrence.

(3) Survillance of Reactor Coolant System Pressure Isolation Valves

a. Periodic leakage testing* on each valve listed in Table 2-9 shall be accomplished prior co entering the power operation

* To satisfy ALARA requirements, leakage may be measured indirectly (as froc the perforance of pressure Indicators) if acconplotshed in accordance with approved procedures and supported by computations showing that the nethod

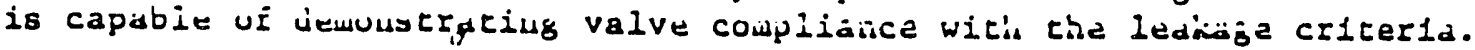


3.0 SURVEILLANCE REOUIRERITS

3.3 Reactor Coolant Susie=, Stean Generator Tubes, and Other Comoonents Subject to ASME XI soilez \& Pressure Vessel Code Insoection and Testing Surveillance (Conrinued)

mode every time the plant is placed in the cold shutdown condition for refiring, each time the plant is placed in a cold shurdown condicion for 72 hours if testing has not been accomplished in the preceding 9 months, and prior to returning the valve to service after maintenance, repair or replacement work. is performed.

b. Whenever the integrity of a pressure isolation valve listed in Table 2-9 cannot be demonstrated the integrity of the remaining valve in each high pressure line having a leaking valve shall be derermined and recorded dally. In addicion, the position of one otner valve located in the high pressure line shall be recorded daily. 

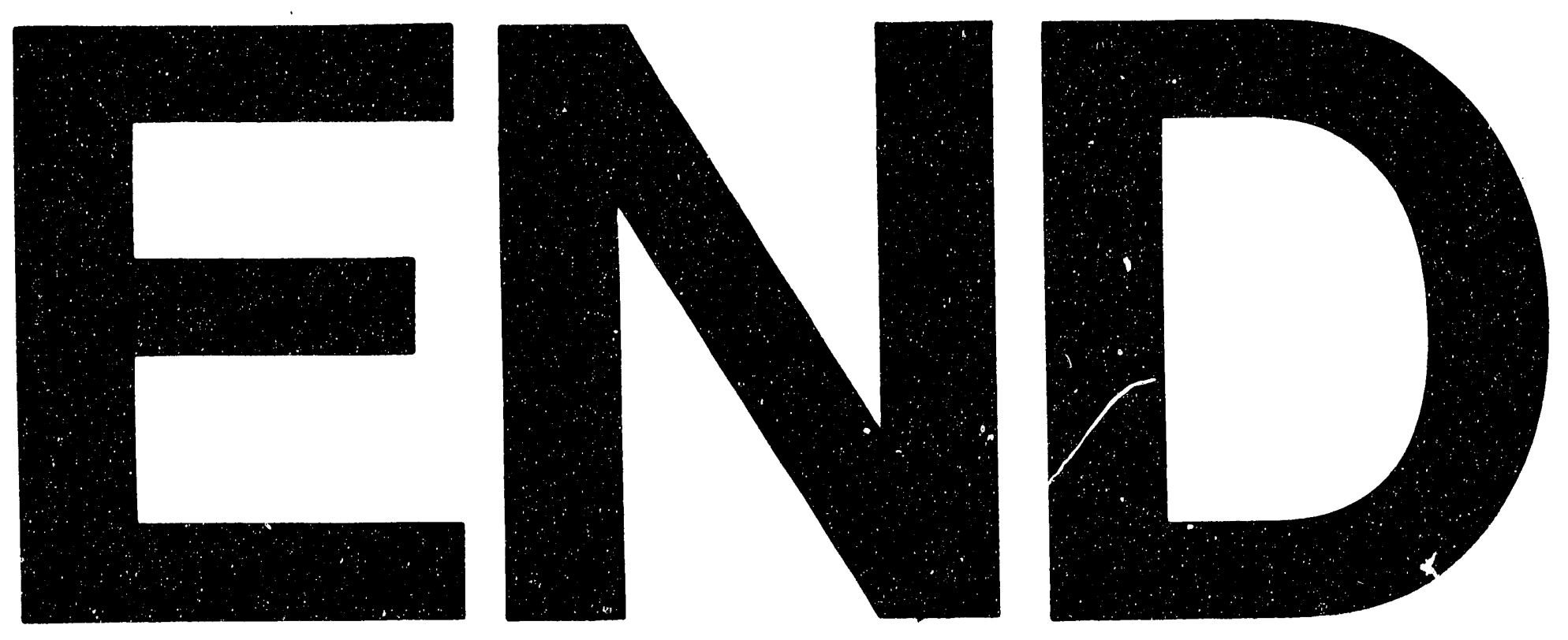

1
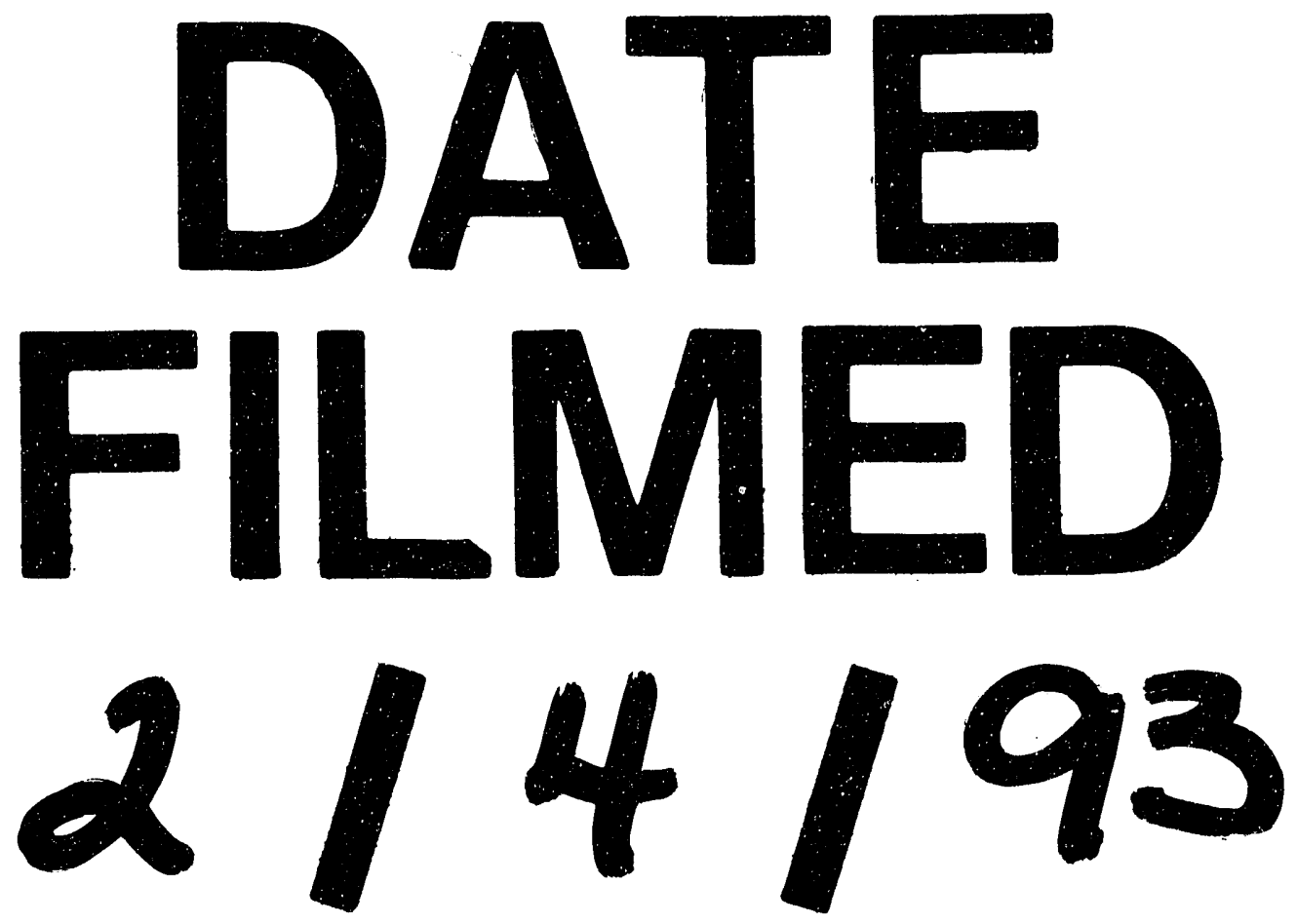